Reconhecimento de sessões http em um modelo para servidor web com diferenciação de serviços 



\title{
Reconhecimento de sessões http em um modelo para servidor web com diferenciação de serviços
}

\author{
Hima Carla Belloni Mourão
}

Orientador: Prof. Dr. Marcos José Santana

Dissertação apresentada ao Instituto de Ciências Matemáticas e de Computação - ICMC-USP, como parte dos requisitos para obtenção do título de Mestre em Ciências de Computação e Matemática Computacional.

USP - São Carlos

Novembro de 2006 



\section{Agradecimentos}

Ao Prof. Marcos Santana, pela orientação prestada e pela confiança demonstrada em meu trabalho.

À Profa. Regina Santana, por sua disponibilidade e opiniões seguras.

Aos demais professores e funcionários do Instituto, por seu exemplo de profissionalismo e dedicação, em especial aos professores do LaSDPC.

Aos meus pais.

Aos meus amigos de São Carlos.

Ao CNPq, pelo apoio financeiro dado a este trabalho. 



\section{Sumário}

Lista de Figuras . . . . . . . . . . . . . . . . . . . . vii

Lista de Tabelas . . . . . . . . . . . . . . . . . . . . . xi

Lista de Abreviaturas e Siglas . . . . . . . . . . . . . . . . . 1

1 Introdução $\quad \mathbf{1}$

1.1 Contextualização . . . . . . . . . . . . . . . . . . . . . . . . . . . . . . . . . . . . .

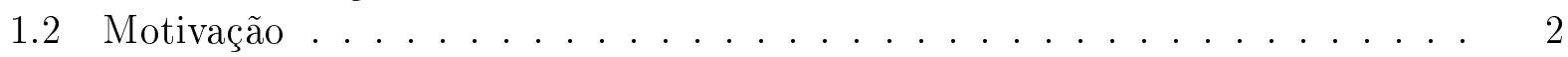

1.3 Objetivos . . . . . . . . . . . . . . . . . . . . . . . . 3

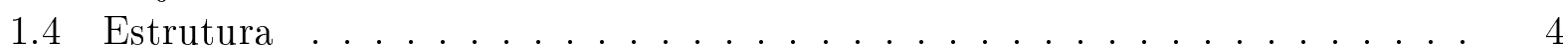

$\begin{array}{ll}\text { Referências Bibliográficas } & 5\end{array}$

2 Infra-estrutura e Desempenho da Web 5

2.1 Considerações Iniciais . . . . . . . . . . . . . . . . . . . . . . . . . . . . . . . . . .

2.2 A Internet . . . . . . . . . . . . . . . . . . . . . 5

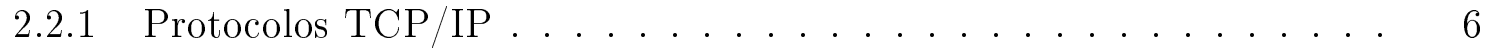

2.2 .2 A Arquitetura TCP $/ \mathrm{IP} \ldots \ldots \ldots \ldots$

2.3 A Organização da Web . . . . . . . . . . . . . . . . . . . . . 8

2.3.1 Interações Cliente-Servidor na Web . . . . . . . . . . . . . . 9

2.4 Protocolo HTTP . . . . . . . . . . . . . . . . . . . . . . . . . . . . . . . . . 10

2.4.1 Mensagens de Requisição e Resposta . . . . . . . . . . . . . . . . 11

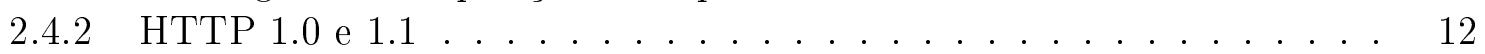

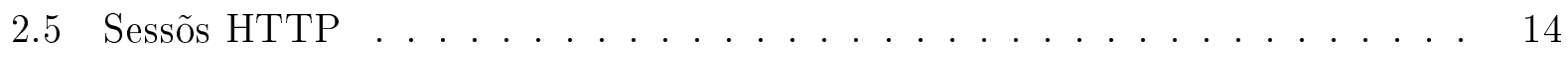

2.6 Caracterização da Carga de Trabalho . . . . . . . . . . . . . . . . . . . . 14

2.6.1 Partição da Carga de Trabalho . . . . . . . . . . . . . . 15

2.7 Considerações Finais . . . . . . . . . . . . . . . . . . . . 16

3 Qualidade de Serviço $\quad 17$

3.1 Considerações Iniciais . . . . . . . . . . . . . . . . . . . . . . . . . . . . . . . . . . . . .

3.2 Limitações da Internet Atual . . . . . . . . . . . . . . . . . . . . . . . . . . . . . . . . . . . . . . . . . . . . . .

3.3 Conceitos Básicos de QoS . . . . . . . . . . . . . . . . . . . . . . 18

3.3.1 Caracterização do Tráfego . . . . . . . . . . . . . . . . . . . . . . . . . . . . . . . . 19

3.4 Arquitetura para QoS . . . . . . . . . . . . . . . . . . . . . . . . . . . . . . . . . . . .

3.4 .1 Serviços Integrados . . . . . . . . . . . . . . . . . . 20

3.4 .2 Serviços Diferenciados . . . . . . . . . . . . . . . 22

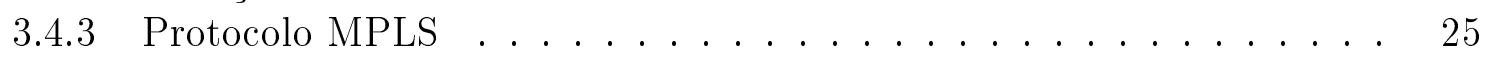


3.5 Serviços Diferenciados em Nível de Aplicação . . . . . . . . . . . . . . . . . 26

3.6 Considerações Finais . . . . . . . . . . . . . . . . . . . . . . . 26

4 Servidor Web com Diferenciação de Serviços (SWDS) 29

4.1 Considerações Iniciais . . . . . . . . . . . . . . . . . . . . . . . . . . . . . . . 29

4.2 Modelo do Servidor Web com Diferenciação de Serviços . . . . . . . . . . . . 29

4.3 Controle de Admissão . . . . . . . . . . . . . . . . . . . . . . . . . . . . . . . 31

4.3.1 Mecanismos de Controle de Admissão . . . . . . . . . . . . . . . . . . 32

4.4 Mecanismos de Diferenciação de Serviços . . . . . . . . . . . . . . . . . . . . . . . . . . . . . . . . . . . . . . 34

4.4.1 Reserva de Recursos . . . . . . . . . . . . . . . . . . . . 34

4.4.2 Mecanismo de Prioridades Rigoroso . . . . . . . . . . . . . . . . 34

4.4.3 Mecanismo de Prioridades Adaptativo . . . . . . . . . . . . . . . 34

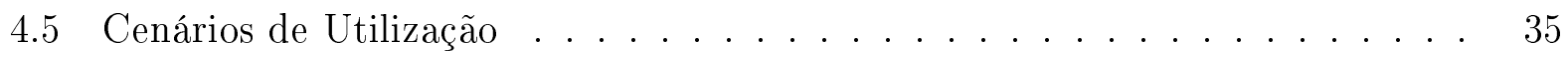

4.6 Considerações Finais . . . . . . . . . . . . . . . . . . . . . . . 36

5 Reconhecimento de Sessões no SWDS $\quad 37$

5.1 Considerações Iniciais . . . . . . . . . . . . . . . . . . . . . . . . 37

5.2 Característica de Reconhecimento de Sessões . . . . . . . . . . . . . . . . . 38

5.3 Módulo de Reconhecimento de Sessões no SDWS . . . . . . . . . . . . . . . 39

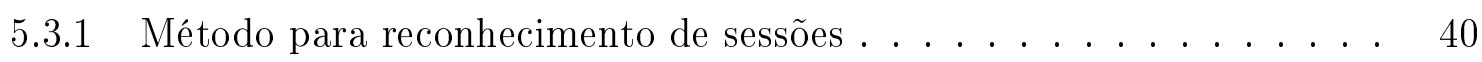

5.4 Geração da Carga de Trabalho . . . . . . . . . . . . . . . . . . . . . . . . . . . . . . . . . . . . .

5.4 .1 Estudo do $\log \ldots \ldots \ldots$. . . . . . . . . . . . . . . 41

5.4 .2 Processo de Construção da Carga . . . . . . . . . . . . . . . . . . 42

5.5 Classificação de Requisições . . . . . . . . . . . . . . . . . . . . . . . . . . . . . . . . . . . . . . . . .

5.6 Experimentação do Modelo . . . . . . . . . . . . . . . . . . . . 45

5.6.1 Validação do Modelo . . . . . . . . . . . . . . . . . . 45

5.6 .2 Parametrização . . . . . . . . . . . . . . . . . . . . . . . . 46

5.7 Metodologia de Teste . . . . . . . . . . . . . . . . . . . . . . 46

5.8 Considerações Finais . . . . . . . . . . . . . . . . . . . . . . 47

6 Controle de Admissão de Sessões $\quad 49$

6.1 Considerações Iniciais . . . . . . . . . . . . . . . . . . . . . . . . . . . . . . . . . . . . . . .

6.2 Controle de Admissão de Sessões - CAS . . . . . . . . . . . . . . . . . . . 50

6.2.1 Arquitetura do Módulo de Controle de Admissão de Sessões . . . . . 51

6.2 .2 Seleção das Métricas . . . . . . . . . . . . . . . . . . . . . . . . . . . . . . . 53

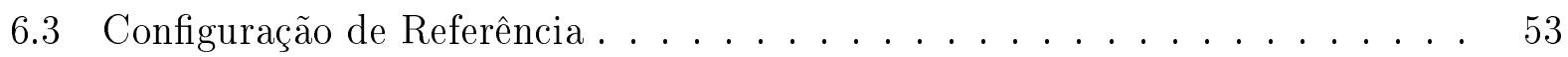

6.4 Política de Admissão Hard-Threshold . . . . . . . . . . . . . . . . . . . . . . 55

6.4.1 Descrição do Mecanísmo . . . . . . . . . . . . . . . . . . . . 55

6.4.2 Resultados Experimentais . . . . . . . . . . . . . 56

6.5 Política de Admissão Baseada em Sessão Modelo . . . . . . . . . . . . . . . . 57

6.5.1 Descrição do Mecanismo . . . . . . . . . . . . . . . . . . . . . 57

6.5.2 Resultados Experimentais . . . . . . . . . . . . . 61

6.6 Comparação dos resultados para as Políticas do CAS . . . . . . . . . . . 63

6.7 Considerações Finais . . . . . . . . . . . . . . . . . . . . 63 
7 Controle de Admissão de Requisições $\quad 65$

7.1 Considerações Iniciais . . . . . . . . . . . . . . . . . . . . . . . . . . . . . 65

7.2 Mecanismo de Controle . . . . . . . . . . . . . . . . . . . 66

7.2.1 Políticas de Admissão de Requisições . . . . . . . . . . . . . . 66

7.2 .2 Seleção de Métricas . . . . . . . . . . . . . . . . . . . . . . . . . 67

7.3 Admissão segundo o Tamanho das Filas Sem Negociação . . . . . . . . . . . 67

7.3.1 Descrição do Mecanismo . . . . . . . . . . . . . . . . . 67

7.3.2 Resultados Experimentais . . . . . . . . . . . . . 68

7.4 Admissão segundo o Tamanho de Fila com Negociação . . . . . . . . . . . . 69

7.4.1 Descrição do Mecanismo . . . . . . . . . . . . . . . . . . 69

7.4 .2 Políticas de Negociação para Descarte de Sessões . . . . . . . . . . . 70

7.4.3 Comparação de resultados experimentais entre políticas de negociação 71

7.5 Comparação de resultados entre algoritmos de CAR . . . . . . . . . . . . 73

7.6 Controle de Admissão de Sessão e Controle de Admissão de Requisições . . . 74

7.6.1 Comparação dos resultados para os CAS com CAR Tamanho de Fila Sem Negociação . . . . . . . . . . . . . . . . . . . . . . 74

7.6.2 Comparação dos resultados para os CAS com CAR Tamanho de Fila e Negociação de Sessão Mais Recente . . . . . . . . . . . . . 76

7.6.3 Comparação dos resultados para os CAS com CAR Tamanho de Fila e Negociação de Sessão Mais Recente e Menor Duração . . . . . . . . 78

7.6.4 Comparação dos resultados para os CAS com CAR Tamanho de Fila e Negociação de Sessão Mais Recente, Maior Duração e de Classe Baixa 80

7.6.5 Comparação dos resultados para os CAS com CAR Tamanho de Fila e Negociação de Sessão Mais Recente e de Menor Tamanho . . . . . . 82

7.6.6 Comparação Final . . . . . . . . . . . . . . . . . . . . 84

7.7 Considerações Finais . . . . . . . . . . . . . . . . . . . . . 85

8 Conclusão $\quad 87$

8.1 Visão Geral . . . . . . . . . . . . . . . . . . . . . . . . . 87

8.2 Principais Resultados e Contribuições . . . . . . . . . . . . . . . . . . . . . . 89

8.3 Trabalhos Futuros . . . . . . . . . . . . . . . . . . . . . . . . 91

$\begin{array}{ll}\text { Referências Bibliográficas } & 93\end{array}$ 



\section{Lista de Figuras}

2.1 As Camadas da Arquitetura TCP / IP . . . . . . . . . . . . . . . 7

2.2 Estrutura de uma URL . . . . . . . . . . . . . . . . . . . . . . . 9

2.3 Exemplo de Requisição e Resposta HTTP . . . . . . . . . . . . . . . . . . . 12

4.1 Servidor Web com Diferenciação de Serviços (SWDS) (Teixeira, 2004) . . . 30

4.2 Módulo de Controle de Admissão (Teixeira, 2004) . . . . . . . . . . . . . . . 32

5.1 Modelo SWDS com o novo módulo de reconhecimento de sessões . . . . . . . 39

6.1 Modelo SWDS com o novo controle de admissão de sessões . . . . . . . . . . 50

6.2 Arquitetura do Controle de Admissão de Sessões . . . . . . . . . . . . . . . . . 52

6.3 Sessão Modelo obtido com o Método 1 de leitura do $\log \ldots$. . . . . . . . . . . 60

6.4 Sessão Modelo obtido com o Método 2 de leitura do $\log$. . . . . . . . . . . . 61

7.1 Throughput (Sessões/seg) para os CAS em conjunto com CAR utilizando o método 1 de leitura do $\log \ldots \ldots \ldots$. . . . . . . . . . . 84

7.2 Throughput (Sessões/seg) para os CAS em conjunto com CAR utilizando o método 2 de leitura do $\log \ldots \ldots$. . . . . . . . . . . . 84 



\section{Lista de Tabelas}

2.1 Métodos definidos pelo protocolo HTTP . . . . . . . . . . . . . . . . . 13

2.2 Classes de código de status das respostas HTTP . . . . . . . . . . . . . . 13

5.1 Parâmetros do modelo SWDS . . . . . . . . . . . . . . . . . . . . 47

6.1 Resultados de Referência para Sessões (Sem CAS e CAR) . . . . . . . . . . . 54

6.2 Resultados de Referência para Requisições (Sem CAS e CAR) . . . . . . . . 54

6.3 Resultados de Referência de Maior Tamanho das Filas para os Servidores (Sem CAS e CAR) . . . . . . . . . . . . . . . . 55

6.4 Resultados para Sessões utilizando a Política Hard-Threshold . . . . . . . . . 56

6.5 Maior Tamanho das Filas para os Servidores utilizando a Política HardThreshold para o Controles de Admissão de Sessões . . . . . . . . . . . . . . 57

6.6 Resultados para Requisições utilizando a Política Hard-Threshould . . . . . . 57

6.7 Resultados para Sessões utilizando a Política Baseada em Sessão Modelo . . 62

6.8 Resultados para Requisições utilizando a Política Baseada em Sessão Modelo 62

6.9 Maior Tamanho das Filas para os Servidores utilizando a Política Baseada em Sesão Modelo para o Controles de Admissão de Sessões . . . . . . . . . . . . 63

7.1 Resultados sobre Sessões para Política de Admissão Segundo o Tamanho das Filas Sem Negociação . . . . . . . . . . . . . . . . . . . . . .

7.2 Resultados para Requisições para Política de Admissão Segundo o Tamanho das Filas Sem Negociação . . . . . . . . . . . . . . . . . 69

7.3 Comparação para Requisições entre Políticas de Negociação . . . . . . . . . 71 7.4 Comparação para Sessões entre Políticas de Negociação . . . . . . . . . . . . 72 7.5 Resultados para Classes de Sessões para CAR com Negociação . . . . . . . 73

7.6 Resultados sobre Sessões para CAS em conjunto com CAR por Tamanho de Fila sem Negociação utilizando o método 1 de leitura do $\log$. . . . . . . . . 75

7.7 Resultados sobre Sessões para CAS em conjunto com CAR por Tamanho de Fila sem Negociação utilizando o método 2 de leitura do $\log$. . . . . . . . .

7.8 Resultados sobre Requisições para CAS em conjunto com CAR por Tamanho de Fila sem Negociação utilizando o método 1 de leitura do $\log$. . . . . . .

7.9 Resultados sobre Requisições para CAS em conjunto com CAR por Tamanho de Fila sem Negociação utilizando o método 2 de leitura do $\log$. . . . . . . .

7.10 Resultados sobre Sessões para CAS em conjunto com CAR por Tamanho de Fila com Negociação de Sessão Mais Recente utilizando o método 1 de leitura do $\log \ldots \ldots \ldots \ldots \ldots \ldots$ 9 
7.11 Resultados sobre Sessões para CAS em conjunto com CAR por Tamanho de Fila com Negociação de Sessão Mais Recente utilizando o método 2 de leitura

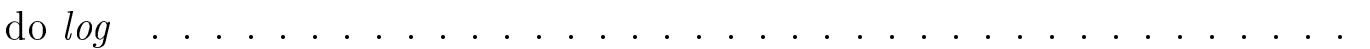

7.12 Resultados sobre Requisições para CAS em conjunto com CAR por Tamanho de Fila com Negociação de Sessão Mais Recente utilizando o método 1 de

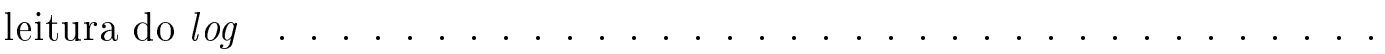

7.13 Resultados sobre Requisições para CAS em conjunto com CAR por Tamanho de Fila com Negociação de Sessão Mais Recente utilizando o método 2 de leitura do $\log$ Recente . . . . . . . . . . . . . . . . .

7.14 Resultados sobre Sessões para CAS em conjunto com CAR por Tamanho de Fila com Negociação de Sessão Mais Recente e de Menor Duração utilizando o método 1 de leitura do $\log \ldots \ldots$. . . . . . . . . . . . .

7.15 Resultados sobre Sessões para CAS em conjunto com CAR por Tamanho de Fila com Negociação de Sessão Mais Recente e de Menor Duração utilizando o método 2 de leitura do $\log \ldots \ldots \ldots \ldots$

7.16 Resultados sobre Requisições para CAS em conjunto com CAR por Tamanho de Fila com Negociação de Sessão Mais Recente e de Menor Duração utilizando o método 1 de leitura do $\log \ldots \ldots \ldots$. . . . . . . . . . . .

7.17 Resultados sobre Requisições para CAS em conjunto com CAR por Tamanho de Fila com Negociação de Sessão Mais Recente e de Menor Duração utilizando o método 2 de leitura do $\log \ldots \ldots \ldots \ldots$

7.18 Resultados sobre Sessões para CAS em conjunto com CAR por Tamanho de Fila com Negociação de Sessão Mais Recente e de Menor Duração e de Classe Baixa utilizando o método 1 de leitura do $\log \ldots$. . . . . . . . . . . . .

7.19 Resultados sobre Sessões para CAS em conjunto com CAR por Tamanho de Fila com Negociação de Sessão Mais Recente e de Menor Duração e de Classe Baixa utilizando o método 2 de leitura do $\log \ldots$. . . . . . . . . . .

7.20 Resultados sobre Requisições para CAS em conjunto com CAR por Tamanho de Fila com Negociação de Sessão Mais Recente e de Menor Duração e de Classe Baixa utilizando o método 1 de leitura do $\log$. . . . . . . . . . . .

7.21 Resultados sobre Requisições para CAS em conjunto com CAR por Tamanho de Fila com Negociação de Sessão Mais Recente e de Menor Duração e de Classe Baixa utilizando o método 2 de leitura do $\log$. . . . . . . . . . . . .

7.22 Resultados sobre Sessões para CAS em conjunto com CAR por Tamanho de Fila com Negociação de Sessão Mais Recente e de Menor Tamanho utilizando o método 1 de leitura do $\log \ldots$. . . . . . . . . . . . . . .

7.23 Resultados sobre Sessões para CAS em conjunto com CAR por Tamanho de Fila com Negociação de Sessão Mais Recente e de Menor Tamanho utilizando o método 2 de leitura do $\log \ldots$. . . . . . . . . . . . . . . .

7.24 Resultados sobre Requisições para CAS em conjunto com CAR por Tamanho de Fila com Negociação de Sessão Mais Recente e de Menor Tamanho utilizando o método 1 de leitura do $\log \ldots \ldots \ldots$. . . . . . . . . .

7.25 Resultados sobre Requisições para CAS em conjunto com CAR por Tamanho de Fila com Negociação de Sessão Mais Recente e de Menor Tamanho utilizando o método 2 de leitura do $\log \ldots$. . . . . . . . . . . . . . . . 


\section{Lista de Abreviaturas e Siglas}

AF Assured Forwarding

ATM Asynchronous Transfer Mode

CAR Controle de Admissão de Requisições

CAS Controle de Admissão de Sessões

CGI Common Gateway Interface

DNS Domain Name Service

DS Differentiated Services

DSCP Differentiated Services Codepoint

EF Expedited Forwarding

FTP File Transfer Protocol

HTML HyperText Markup Language

HTTP Hypertext Transfer Protocol

IETF Internet Engineering Task Force

IP Internet Protocol

ISO International Organization for Standardization

LaSDPC Laboratório de Sistemas Distribuídos e Programação Concorrente

MIME Multi-Purpose Internet Mail Extensions

MPLS Multi-Protocol Label Switching

NFS Network File System

OSI Reference Model of Open Systems Interconnection

PHB Per-Hop-Behavior 
QoS Quality of Service

RFC Request for Comments

RSVP Resource Reservation Protocol

SLA Service Level Agreement

SMTP Simple Mail Transfer Protocol

SNMP Simple Network Management Protocol

SWDS Servidor Web com Diferenciação de Serviços

TCP Transfer Control Protocol

UDP User Datagram Protocol

URL Uniform Resource Locators

W3C World Wide Web Consortium

WWW World Wide Web

XHTML Extensible HyperText Markup Language 


\section{Resumo}

Esta dissertação de mestrado aborda a introdução de reconhecimento de sessões http em um modelo de servidor web com serviços diferenciados (SWDS). Algumas técnicas foram desenvolvidas com o objetivo de produzir diferenciação de serviços junto com garantias de que novas sessões poderiam ser aceitas no sistema. Esses objetivos constituem requisitos essenciais na Internet atual, especialmente para aplicações web modernas. Um novo esquema para controle de admissão de sessões foi desenvolvido e introduzido no modelo SWDS, considerando dois mecanismos para aceitar novas sessões, com garantia de finalização. O mecanismo que estima a capacidade do sistema de aceitar novas sessões, baseado em um modelo de sessão construído dinamicamente a partir da carga do sistema, é destacado. A proposta global deste trabalho também considera um controle de admissão de requisições, baseado em sessões, onde a nova política de atendimento criada mantém o sistema livre de sobrecargas e oferece atendimento diferenciado para as sessões. As políticas de negociação desenvolvidas para o controle de admissão de requisições tiveram um papel importante neste trabalho, contribuindo para a priorização do atendimento das sessões. Os resultados obtidos mostram que os controles propostos constituem estruturas fundamentais para a estabilidade do desempenho do sistema, tanto quanto os mecanismos desenvolvidos têm grande importância no atendimento das sessões e, portanto de seus clientes, através de uma abordagem baseada em diferenciação. 



\section{Abstract}

This MSc dissertation approaches the introduction of the HTTP sessions recognition in a web server model with differentiated services (SWDS). Some techniques have been developed aiming at issuing differentiation of services together with guarantees that new sessions could be accepted in the system. These aims constitute essential requirements for the current Internet, especially for modern web applications. A new scheme for the admission control system has been developed and introduced in the SWDS model, considering two mechanisms for accepting new sessions, with guarantee of their finalizations. The mechanism that estimates the system capacity of acceptance of a new session, based on a session model built dynamically from system workload information, is highlighted. The global propose of this work also considers a request admission control, based on sessions, where the new attendance polices created keep the system free from overloads and offer differentiated attendance for the sessions. The negotiation polices developed for request admission control had an important place in this work, contributing for the session attendance prioritization. The results reached show that the controls proposed comprise fundamental structures for system performance stability, as well as the mechanisms developed have great importance in attending sessions and, therefore, their clients by means of a differentiation-based approach. 



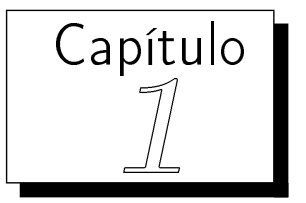

\section{Introdução}

\subsection{Contextualização}

A Internet, Rede Mundial de Computadores, surgiu a partir da ARPANET, meio de transferência de informações entre computadores das bases militares, criado pelo Departamento de Defesa Americano no período da guerra fria entre os Estados Unidos e a ex-União Soviética. A interconexão dos computadores era realizada por um sistema de comutação de pacotes que garantia a integridade da informação enviada pela rede caso alguma das conexões sofresse algum dano. Após isso, as redes voltaram-se para a área acadêmica e mais tarde, os dados passaram a ser transportados entre computadores espalhados pelos continentes (Comer, 2006).

Os dados transferidos pela Internet inicialmente se apresentavam em formato de textos e provinham de aplicações cliente-servidor, tais como correio eletrônico, transferência de arquivos e grupos de notícias. Estes tipos de dados ofereciam pouca carga à rede, relativamente ao cenário atual da Internet. Porém, com o surgimento da World Wide Web (WWW), foi observado um grande aumento do tráfego na rede.

A Web foi um dos fatores responsáveis pela grande popularização da Internet e, com ela, a Internet passou a existir não apenas para fins de pesquisas, restritas às instituições acadêmicas e órgãos governamentais, mas também a ser utilizada para fins informativos, educacionais, de entretenimento e comerciais.

Portanto, ocorreram mudanças não apenas na quantidade do tráfego da Internet, mas também na natureza do mesmo, se tornando uma plataforma para aplicações com conteúdo 
dinâmico, integrado com bases de dados e oferecendo transações comerciais seguras, levando ao estabelecimento do comércio eletrônico (Xiao \& Ni, 1999) (Ghinea \& Angelides, 2004) (Galbraith et al., 2005). Além dessas aplicações, tem-se a incorporação de redes de telefonia, rádio e TV na Internet, o que tende a aumentar ainda mais a demanda sobre a mesma (Stardust, 1999b) (Morrison, 2005) (Hunt \& Arden, 2005).

Entretanto, no projeto da Internet não foi previsto o suporte ao tráfego gerado pelas aplicações atuais. O serviço oferecido por ela atualmente, baseia-se em um modelo de melhor esforço (best-effort), pelo qual a rede procura transportar dados no menor tempo possível, porém, sem garantir a entrega dos mesmos. Contudo, a Web está atingindo seu limite de tráfego. Aumentar a largura de banda, não é suficiente para resolver o problema, pois esse aumento seria consumido rapidamente pela demanda dos usuários. É necessário que a demanda das novas aplicações inseridas na Internet seja atendida adequadamente e, para tanto, devem ser desenvolvidos novos modelos de serviço na rede (Comer, 2006).

\subsection{Motivação}

$\mathrm{Na}$ Internet, ate o momento, todo o tráfego é tratado uniformemente, inclusive pelos servidores web que atendem às requisições baseados em uma política FCFS (First-Come First-Served), não havendo nenhum tipo de diferenciação ou priorização (Yeager \& McGrath, 1996) (Comer, 2006).

Faz-se necessária a existência de diferenciação de serviços na Internet, tanto em nível de rede, quanto em nível de aplicação, pois é observado que nem todos os tipos de tráfego e transações são equivalentes ou têm a mesma prioridade para os usuários (Dovrolis \& Ramanathan, 1999) (Morrison, 2005).

Várias especificações para a provisão de qualidade de serviço sobre redes IP, já foram desenvolvidas sob a coordenação da IETF (Internet Engineering Task Force), dentre elas destacam-se as arquiteturas de Serviços Integrados (Braden et al., 1994) e Diferenciados (Blake et al., 1998).

Entretanto, na grande maioria dos servidores web atuais, não são encontradas características de diferenciação de serviços. Porém, estudos têm sido realizados nessa área, destacando-se o modelo de Servidor Web com Diferenciação de Serviços, SWDS (Teixeira, 2004), cujo objetivo é fornecer serviços diferenciados aos seus clientes, de acordo com suas necessidades e segundo requisitos de QoS previamente estabelecidos.

O modelo de servidor SWDS classifica as requisições e, as atende de forma diferenci- 
ada, dependendo da classe à qual elas pertencem (Teixeira, 2004). No entanto, o modelo não possui a propriedade de reconhecimento de sessões HTTP, característica importante para as aplicações atuais, que requerem garantias de que a transação realizada por meio de uma sessão HTTP, seja concluída.

No cenário atual da Internet, a Web se mostra como um crescente e importante elemento na sociedade. Para muitos consumidores a Web tem se tornado o principal meio de interação com o comércio. Além disso, as transações bancárias via Web estão se tornando cada vez mais comuns entre os usuários da Internet. Em meio desse crescimento da Web, clientes passam a exigir serviços melhores e diferenciados dos servidores web (Galbraith et al., 2005). Para tanto, faz-se necessário o fornecimento de maior nível de confiabilidade no atendimento das requisições pertencentes às sessões de usuários, pois uma sessão se resume a uma seqüência de requisições de um único cliente (Arlitt, 2000).

\subsection{Objetivos}

O objetivo geral do presente trabalho é adaptar o modelo de servidor web SWDS proposto em (Teixeira, 2004), incluindo o recurso de reconhecimento de sessões HTTP, com o intuito de melhorar o fornecimento de serviços diferenciados na Internet em nível de aplicação. Dentre os objetivos específicos desta dissertação, destacam-se:

- Modelagem da técnica de reconhecimento de sessões HTTP e sua incorporação ao modelo de servidor SWDS;

- Identificação de critérios para a classificação de sessões HTTP, a fim de subdividí-las em prioridades de atendimento;

- Desenvolvimento de algoritmos para admissão de sessões HTTP ao sistema, a fim de prezar pelo princípio de finalização das sessões;

- Desenvolvimento de algoritmos para o controle de admissão de requisições baseados em informações de sessões, de modo a evitar sobrecarregar o servidor e ao mesmo tempo respeitar o atendimento das sessões;

- Avaliar o impacto da introdução da característica de reconhecimento de sessões no modelo de servidor web com diferenciação de serviços (SWDS);

- A partir da experiência adquirida, identificar novos rumos para a pesquisa na área de serviços diferenciados para sessões HTTP, dando origem a novos projetos. 
Esta dissertação contribui para um melhor entendimento sobre as características de uma sessão HTTP e os aspectos relacionados à qualidade de seu atendimento e a diferenciação nos serviços fornecidos à ela pelos servidores web.

\subsection{Estrutura}

No Capítulo 2 é apresentada a infra-estrutura da Internet, seus protocolos e principais serviços, com destaque à Web, ao protocolo HTTP e às sessões. É comentado também sobre a caracterização de carga na Web.

No Capítulo 3 é abordado o tópico de diferenciação de serviços na Internet e são discutidas as limitações do seu modelo atual de atendimento a clientes. São apresentados conceitos da área de qualidade de serviço e detalhadas as arquiteturas de serviços integrados e diferenciados. É introduzida a necessidade de se fornecer qualidade de serviço na Internet, em nível de aplicação, particularmente nos servidores web.

O Capítulo 4 tem por objetivo apresentar o modelo SWDS, Servidor Web com Diferenciação de Serviços, e descrever sobre seus principais componentes. É fornecida uma visão geral dos algoritmos de diferenciação de serviços e de controle de admissão implementados no modelo. Finalmente, são apontados alguns cenários de utilização de serviços diferenciados na Web.

No Capítulo 5 estudam-se os conceitos sobre sessões HTTP e a adaptação do modelo SWDS ao reconhecimento de sessões é descrita. Explica-se também, o método abordado para a classificação das requisições, e por fim, descreve-se como foi realizada a experimentação do modelo com a sua nova característica.

O Capítulo 6 apresenta o módulo desenvolvido e adaptado ao modelo SWDS para a admissão de sessões. Sua arquitetura é descrita e os algoritmos implementados para esse controle são estudados. Os resultados obtidos dos experimentos realizados com o uso desse controle são apresentados e comparados.

O Capítulo 7 aborda aspectos de controle de sobrecarga em servidores web, onde são descritos os algoritmos de controle de admissão de requisições desenvolvidos, cujo princípio é manter o sistema livre de sobrecargas e ao mesmo tempo prezar pelo atendimento de sessões.

Finalmente, o Capítulo 8 apresenta as conclusões e principais contribuições desta dissertação, além de de fornecer indicações para trabalhos futuros. 


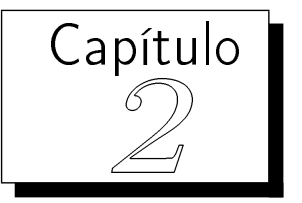

\section{Infra-estrutura e Desempenho da Web}

\subsection{Considerações Iniciais}

Este trabalho tem como objetivo, contribuir para a melhoria dos serviços oferecidos pelos servidores web que, freqüentemente, se constituem em um dos gargalos do sistema. Em específico, este trabalho visa otimizar o modelo de servidor web com diferenciação de serviços (SWDS) proposto em (Teixeira, 2004), adicionando a este a capacidade de reconhecimento de sessões HTTP.

Portanto, neste capítulo será dada uma visão geral da Internet, destacando-se seus serviços e os protocolos da arquitetura TCP/IP que constituem sua infra-estrutura. Será abordada a World Wide Web, sua forma de organização e os tipos de aplicações possíveis de serem executados sobre a mesma. Será feita também, uma descrição do protocolo HTTP, e sessões HTTP. Por fim, é dada atenção especial à caracterização de carga da rede, que servirá de base para a validação deste trabalho.

\subsection{A Internet}

Inúmeras pesquisas foram realizadas visando à criação da tecnologia que permitisse a interligação de redes e computadores no início dos anos 70. A Internet foi criada como solução para essa proposta e tornou-se muito maior do que seus criadores poderiam prever, sendo utilizada não apenas para pesquisas acadêmicas como em seu início, mas fortemente para fins comerciais. 


\subsubsection{Protocolos TCP/IP}

O TCP/IP tornou-se um padrão para a interligação de computadores, tanto em redes locais quanto em redes de longa distância. Criado juntamente com a Internet, esse protocolo apresenta características que o destaca entre outros protocolos, tais como a sua disponibilidade gratuita e a independência de plataformas de hardware e software para seu funcionamento (Comer, 2006).

O TCP/IP é independente da tecnologia de rede, usando a comutação de pacotes para realizar a comunicação entre hosts. Além disso, pode ser empregado sobre diferentes protocolos das camadas de enlace e física, de forma transparente para as aplicações.

Outra característica importante é que o TCP/IP faz a entrega de dados de forma mais confiável, utilizando para isso um mecanismo de acknowledgements entre a origem e o destino final de uma comunicação e não somente entre pares de máquinas ao longo do caminho.

As especificações dos protocolos TCP/IP estão livremente disponíveis na Internet, através de RFCs (Request for Comments), promulgadas pela IETF (Internet Engineering Task Force).

\subsubsection{A Arquitetura TCP/IP}

O modelo de organização de software de comunicação mais conhecido é o modelo OSI (Reference Model of Open Systems Interconnection) da ISO (International Organization for Standardization), que propõe uma organização de arquitetura em sete camadas: Aplicação, Apresentação, Sessão, Transporte, Rede, Enlace de dados e Física (Tanenbaum, 2002).

O modelo TCP/IP, também apresenta uma arquitetura dividida em quatro camadas: Aplicação, Transporte, Internet e Acesso à rede, equivalentes as camadas do modelo OSI conforme demonstrado na Figura 2.1.

\section{Camada de Acesso à Rede}

A Camada de Acesso à Rede permite que os dados sejam entregues entre computadores conectados diretamente. Ela se encontra no nível mais baixo da pilha TCP/IP e utiliza vários protocolos de acesso à rede, conforme o tipo de rede disponível. A flexibilidade dos protocolos TCP/IP em funcionar em diversos meios físicos é conseguida graças a essa camada. 


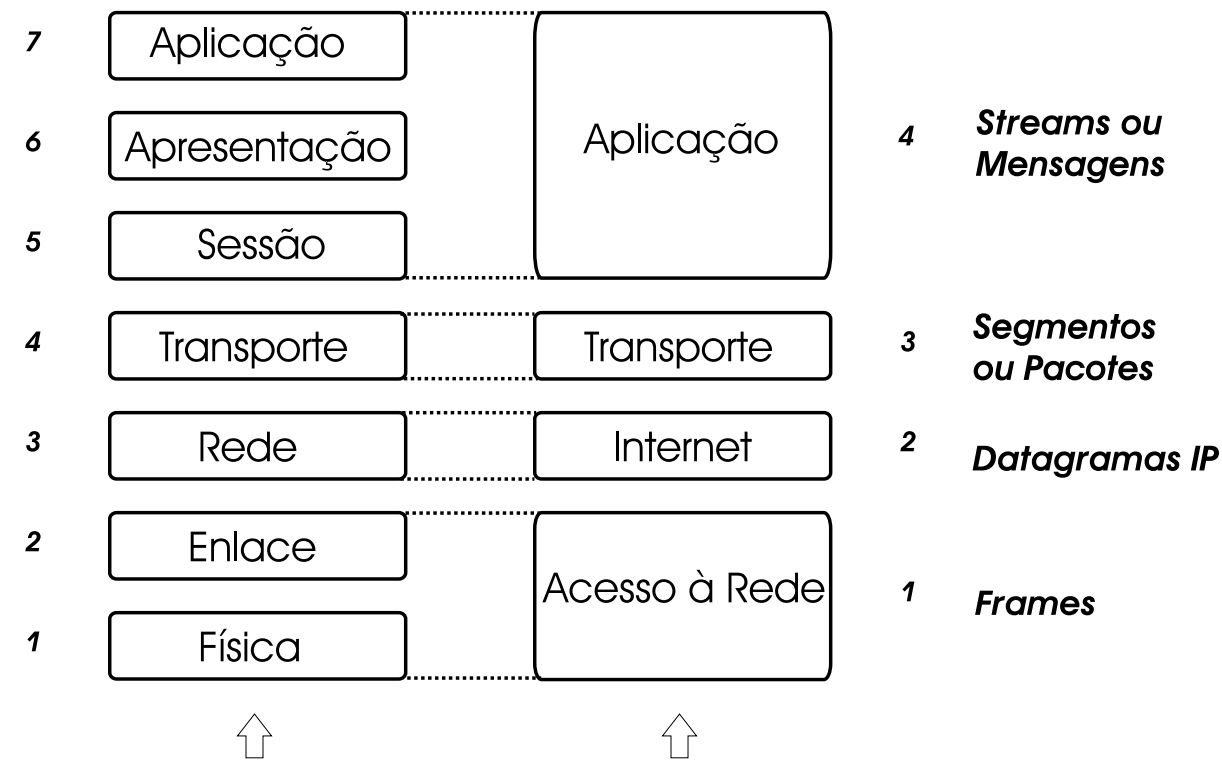

Modelo de Referência OSI

Modelo TCP/IP

Figura 2.1: As Camadas da Arquitetura TCP/IP

Essa camada também faz o encapsulamento dos datagramas IPs nos frames usados na rede, e converte os endereços IP para o formato da rede.

\section{Camada de Internet}

A Camada de Internet permite a comunicação entre duas máquinas da rede. Nessa camada está definido o principal elemento da família TCP/IP, o protocolo IP (Internet Protocol), conforme a RFC 791 (Postel, 1981b).

O protocolo IP fornece o serviço de entrega de pacotes sobre o qual todas as redes TCP/IP funcionam (Hunt, 2002), onde as informação são enviadas dentro de um datagrama, definido pelo protocolo IP.

O IP também é responsável pelo endereçamento da rede, pelo roteamento dos datagramas entre os hosts e pela fragmentação e remontagem dos datagramas ao passarem de uma camada para outra da pilha TCP/IP.

O protocolo IP é não orientado à conexão, onde, cada datagrama contém informações necessárias para que possa ser roteado de forma independente, não requerendo troca de informações de controle iniciais (handshaking), para que uma comunicação seja iniciada. O IP também é um protocolo não-confiável, pois ele não provê mecanismos de detecção e controle de erros. 
Outro protocolo presente na camada de Internet é o ICMP (Internet Control Message Protocol), definido pela RFC 792 (Postel, 1981a), e é de sua responsabilidade a troca de mensagens de controle de fluxo, de redirecionamento de rotas e de detecção de erros.

\section{Camada de Transporte}

A Camada de Transporte permite a comunicação fim-a-fim entre dois hosts ou, mais especificamente, processos executados em hosts conectados à Internet.

Nessa camada está definido o TCP (Transmission Control Protocol). Esse protocolo é orientado à conexão, isto é, uma conexão lógica fim-a-fim é estabelecida entre os dois hosts, antes de iniciar a comunicação. Para isso, é realizado o chamado three-way handshake, onde mensagens de controle são trocadas inicialmente (Comer, 2006). O TCP fornece um serviço confiável, garantindo que os dados cheguem sem erros ao seu destino e também faz o controle de fluxo. O TCP está descrito na RFC 793 (Postel, 1981c).

Outro protocolo definido nessa camada, é o UDP (User Datagram Protocol), especificado na RFC 768 (Postel, 1980). É um protocolo não orientado à conexão, oferecendo um serviço não-confiável. Esse protocolo transmite os dados denominados pacotes, que são mapeados sobre os datagramas IP. O UDP é indicado para a construção de aplicações cliente-servidor, principalmente em redes locais (Coulouris et al., 2000). Mensagens DNS (Domain Name Service), SNMP (Simple Network Management Protocol) e algumas aplicações de transmissão de áudio e vídeo utilizam o protocolo UDP.

\section{Camada de Aplicação}

Essa camada se encontra no mais alto nível da pilha TCP/IP. Nela estão os processos que utilizam os serviços da camada de transporte para a entrega dos dados, podendo escolher entre os serviços oferecidos pelos protocolos TCP ou UDP. É nessa camada que são encontradas as aplicações dos usuários e os protocolos de aplicação, tais como TELNET, FTP, DNS, HTTP, NFS, SMTP, entre outros.

\subsection{A Organização da Web}

A World Wide Web, WWW ou simplesmente Web, criada no início dos anos 90, foi responsável pela maior parte do tráfego na Internet por volta de 1995 (Comer, 2006), superando serviços como FTP e e-mail. Com toda a populariadade adquirida, muitos usuários pensam que a Web é a própria Internet. 
A Web é considerada um sistema de hipertexto em escala global e uma grande plataforma cliente-servidor, que funciona em ambientes heterogêneos tanto de hardware quanto de software. Através de browsers ou navegadores, os usuários acessam as informações que são armazenadas em servidores web ou HTTP espalhados por todos os continentes (Orfali et al., 1999).

A linguagem HTML e o protocolo HTTP são dois padrões sobre os quais a Web funciona, garantindo, assim, a sua portabilidade. A HTML (W3C, 1999), (W3C, 2000) é o idioma universal falado na Web onde as tags HTML descrevem a estrutura do documento, fornecem informações sobre sua formatação e estabelecem os links com outros documentos ou recursos da Web. Outros padrões, como o XML (W3C, 2003), surgiram recentemente como novas linguagens. O protocolo HTTP é utilizado para a comunicação entre os browsers e os servidores web e funciona sobre o TCP.

Uma característica importante na organização da Web é seu sistema de nomenclatura baseado em URLs (Uniform Resource Locators). Uma URL pode identificar páginas HTML, um recurso, ou ainda, um objeto qualquer existente na Internet. Ela apresenta a estrutura vista na Figura 2.2, composta de:

- Protocolo. Informa qual é protocolo utilizado para o transporte dos dados.

- Nome do servidor. Um endereço IP ou nome de um host válido.

- Número da porta. Onde um processo, no servidor, aguarda mensagens. Um valor default, como porta 80 para HTTP, 21 para FTP podem ser utilizados.

- Localização do recurso. Path ou caminho até o recurso.

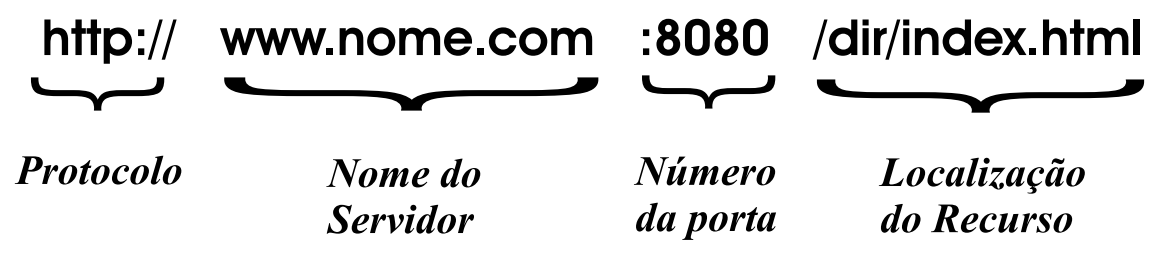

Figura 2.2: Estrutura de uma URL

\subsubsection{Interações Cliente-Servidor na Web}

A Web é considerada como uma grande plataforma cliente-servidor onde um servidor recebe as requisições e, sendo consideradas válidas, as interpreta, retornando os objetos 
requisitados ao cliente. Os objetos podem estar armazenados no sistema de arquivos do servidor (Páginas Estáticas) ou serem gerados dinamicamente por um programa ou script invocado no servidor (Páginas Dinâmicas).

\section{Páginas Estáticas}

$\mathrm{Na}$ fase inicial da Web, os recursos solicitados eram, essencialmente, documentos HTML fisicamente armazenados no sistema de arquivos dos servidores web. Portanto, as transações cliente-servidor eram chamadas como two-tier ou, de duas camadas, onde os clientes por meio de browsers, acessavam uma infra-estrutura de servidores de documentos HTML obtendo, deste modo, as Páginas Estáticas.

\section{Páginas Dinâmicas}

O protocolo CGI (Common Gateway Interface) criado em 1995, trouxe uma maior interatividade para a Web, permitindo iniciar uma aplicação do lado servidor, a partir de um browser (Yeager \& McGrath, 1996). No entanto, a independência de plataforma ainda é garantida, pois toda a comunicação entre o browser e o servidor web continua ocorrendo no formato HTML.

O CGI recebe o pedido de execução de aplicação via formulários HTML, onde os parâmetros são digitados no browser pelo usuário e, então, faz a transferência para o programa apropriado, localizado no lado servidor. Esse programa, então, envia uma página dinâmica como resposta. O usuário não tem a percepção de que a página foi gerada dinamicamente a partir de um processo iniciado sob o comando do servidor web, ele apenas a recebe como se fosse uma página estática.

Com a inclusão do script CGI, as interações cliente-servidor passaram a ser chamadas de três camadas ou three-tier, com o browser cliente e as aplicações servidoras como camadas externas e o servidor web acrescido do módulo CGI como camada intermediária.

\subsection{Protocolo HTTP}

O HTTP (Hypertext Transfer Protocol) é um protocolo em nível de aplicação que permite o acesso aos recursos armazenados no servidor web. Todo o tráfego de informações entre os browsers e os servidores web é feito por mensagens HTTP. Os dados são representados conforme o padrão MIME (Multi-Purpose Internet Mail Extensions), definido na RFC 1521 (Borenstein, 1993). 
O HTTP é um protocolo do tipo stateless, isto é, o servidor não guarda nenhuma informação em relação ao estado dos clientes e, portanto, se uma falha na execução da tarefa acontecer, o cliente deverá novamente fornecer todas informações necessárias para que a transação possa ser realizada, a partir de um mecanismo do tipo requisição/resposta (request/reply).

\subsubsection{Mensagens de Requisição e Resposta}

As mensagens de requisição e resposta são definidas pelo protocolo HTTP em um formato padrão. Uma requisição é formada tipicamente por:

- Request line. Linha que informa a ação a ser executada no servidor onde encontra-se o método invocado (HTTP), a localização do objeto no servidor e a versão do protocolo HTTP utilizada.

- Request header. Uma ou mais linhas de cabeçalho contendo informações do cliente, para informar ao servidor, por exemplo, os tipos de dados que ele é capaz de aceitar.

- Corpo da mensagem. Opcional. É utilizado quando dados adicionais do cliente devem ser enviados ao servidor.

O protocolo HTTP determina que uma mensagem de resposta deve conter:

- Response header. Neste cabeçalho é encontrada a versão do protocolo e o código de status com o seu significado.

- Request header. Composto de vários campos nos quais estão contidas informações das características do servidor e do objeto retornado para o cliente.

- Corpo da mensagem. Está contido o objeto retornado ao cliente, em geral, um documento HTML, precedido por uma linha em branco.

Na Figura 2.3 é demostrado um exemplo de Requisição e Resposta, onde um cliente solicita (GET) o arquivo /doc/file.html do servidor www.nome.com usando o protocolo HTTP/1.1. O campo Accept no cabeçalho, informa que o cliente é capaz de receber textos em formato HTML (text/html) e imagens em formato JPEG (image/jpeg). O tipo de browser do cliente é mostrado pelo campo User-Agent.

A resposta do servidor diz que a requisição foi bem-sucedida indicada pelo código 200. O tipo do servidor web (CERN 3.0) é informado pelo campo Server e o campo Content-Type 
mostra que o objeto retornado é um documento HTML, cujo tamanho é de 51 bytes, indicado pelo campo Content-Lenght. Após a linha em branco encontra-se o documento solicitado.

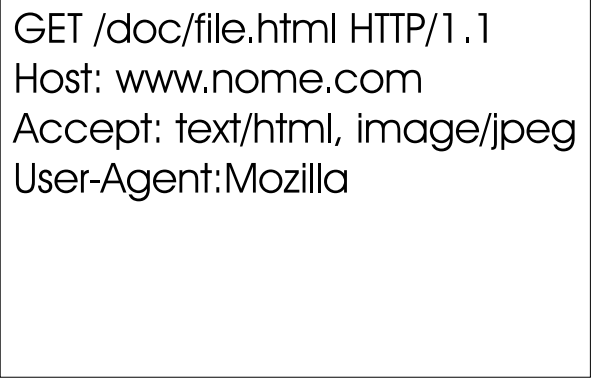

Requisição HTTP

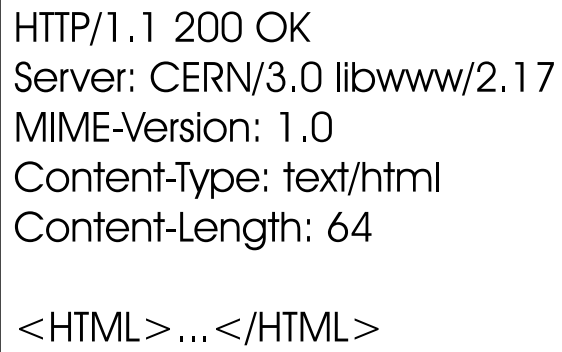

Resposta HTTP

Figura 2.3: Exemplo de Requisição e Resposta HTTP

O cliente pode enviar comandos ao servidor invocando um conjunto de métodos definidos pelo protocolo HTTP ao servidor web. A versão 1.0 do protocolo HTTP é descrita na RFC 1945 (Berners-Lee et al., 1996), na qual estão definidos os métodos GET, HEAD e POST. O protocolo HTTP 1.1 descrito na RFC 2616 (Fielding et al., 1999), são acrescentados os métodos OPTIONS, PUT, DELETE, TRACE e CONNECT a esse conjunto. Uma breve descrição desses métodos pode ser vista na Tabela 2.1.

Para informar o resultado da execução realizada, o servidor retorna em sua resposta HTTP um código de status que se apresentam divididos em classes apresentadas na Tabela 2.2 .

\subsubsection{HTTP 1.0 e 1.1}

É importante destacar que, embora sob o ponto de vista do usuário, uma solicitação de página HTML se resuma, muitas vezes, a apenas um clique do mouse, na verdade ela freqüentemente dá origem a várias solicitações HTTP que são enviadas do browser para o servidor web (seguidas de suas respectivas respostas no sentido contrário). Isso ocorre porque, para cada objeto contido em uma página HTML, é gerada uma requisição independente ao servidor.

Para o protocolo HTTP 1.0, introduzido juntamente com a Web em 1990, é necessário estabelecer uma nova conexão TCP para cada objeto solicitado. Na fase inicial da Internet, 


\begin{tabular}{|c||l|}
\hline Método & Finalidade \\
\hline \hline GET & $\begin{array}{l}\text { Faz a requisição do recurso especificado pela } \\
\text { URL }\end{array}$ \\
\hline POST & $\begin{array}{l}\text { Envia ao servidor, informações do cliente } \\
\text { geralmente digitados em formulários HTML }\end{array}$ \\
\hline HEAD & $\begin{array}{l}\text { Utilizado para obter informações de um re- } \\
\text { curso, sem retorná-lo ao cliente. Testa a val- } \\
\text { idade de links, acessibilidade e a data da úl- } \\
\text { tima atualização }\end{array}$ \\
\hline OPTIONS & $\begin{array}{l}\text { Usado para obter opções de comunicação } \\
\text { disponíveis. Permite o cliente determinar os } \\
\text { requisitos associados ao recurso requisitado }\end{array}$ \\
\hline PUT & Cria ou modifica um recurso no servidor \\
\hline DELETE & $\begin{array}{l}\text { Faz a solicitação para apagar um recurso no } \\
\text { servidor, identificado na URL }\end{array}$ \\
\hline TRACE & Envia mensagem de teste ao servidor \\
\hline CONNECT & Reservado para servidores proxy \\
\hline
\end{tabular}

Tabela 2.1: Métodos definidos pelo protocolo HTTP

\begin{tabular}{|c||c|}
\hline Classe & Descrição \\
\hline \hline $1 \mathrm{xx}$ & Finalidade Informativa \\
\hline $2 \mathrm{xx}$ & Sucesso \\
\hline $3 \mathrm{xx}$ & Redirecionamento \\
\hline $4 \mathrm{xx}$ & Erro do cliente \\
\hline $5 \mathrm{xx}$ & Erro do servidor \\
\hline
\end{tabular}

Tabela 2.2: Classes de código de status das respostas HTTP

não havia problemas quanto a isso, pois os documentos da Web eram constituídos basicamente de texto, porém, as página HTML atuais podem conter várias pequenas imagens, o que pode provocar uma sobrecarga no tráfego da Internet, bem como nos servidores.

A versão 1.1 do protocolo HTTP foi padronizada em 1999 pelo W3C (World Wide Web Consortium), nela as conexões persistentes são padronizadas, permitindo que uma mesma conexão TCP seja usada por várias transações HTTP, o que é bem mais eficiente. No HTTP 1.1 é também realizado o pipelining de requisições, onde várias requisições são enviadas em seqüência, sem aguardar pelas respostas. Também foram incluídos comandos específicos para a manipulação de caches, tanto pelos servidores (web e proxy) quanto pelos clientes. 


\subsection{Sessõs HTTP}

$\mathrm{Na}$ Internet atual, cada vez mais, empresas criam aplicações caracterizadas por intenso uso de conteúdo dinâmico integrado a banco de dados e ainda oferecem segurança no atendimento de transações.

O crescimento da fidelidade dos clientes em relação aos serviços de banco e compras de produtos na Internet pode aumentar muito a demanda aos servidores web. Como conseqüência, além de haver um alto tráfego na rede, deve existir garantias de atendimento a essa demanda, o que tornará difícil o oferecimento de um bom nível de qualidade em relação a esses serviços, no atual modelo da Internet (Wei et al., 2003).

Tipicamente, um acesso ao servidor web ocorre na forma de uma sessão, sendo essa constituída de várias requisições individuais de um mesmo cliente (Arlitt, 2000). Por exemplo, um pedido de um cliente à um site comercial, pode envolver uma requisição para selecionar o produto, outra para prover informações necessárias, uma para estabelecer um acordo de pagamento e finalmente uma última requisição para receber uma confirmação.

Assim, tanto para um cliente, quanto para o site de vendas, necessita-se de qualidade de serviço ao nível de aplicação, a fim de que seja garantido o atendimento de todas as requisições pertencentes a uma transação comercial, de forma que esta seja concluída. Portanto, o sucesso de uma transação é tido somente quando o atendimento de toda uma seqüência de requisições for atendida.

Uma sessão está presente, até mesmo, quando simplesmente um cliente solicita uma única página da Web. Um acesso a uma página de uma empresa, por exemplo, envolve uma requisição à página HTML e após isso são realizadas outras requisições para cada imagem contida no documento. Portanto, para uma única requisição de um cliente a um servidor web, podem ser necessárias várias requisições de arquivos separadamente.

Enfim, para as aplicações atuais, faz-se necessário um acompanhamento do serviço fornecido, capaz de garantir o atendimento completo de qualquer sessão aceita pelo servidor, independente de quão complexa esta seja (Cherkasova \& Phaal, 2002).

\subsection{Caracterização da Carga de Trabalho}

A caracterização da carga de trabalho da Internet é de grande importância para se fazer uma avaliação do desempenho da Web. O sistema pode ser submetido a uma carga real, por exemplo, um trace da demanda pelos recursos armazenados no servidor, ou mesmo 
a um modelo da carga de trabalho do sistema construído com características de interesse, conforme o enfoque que se pretende dar à avaliação de desempenho (Almeida et al., 1996) (Cherkasova \& Gupta, 2002).

É necessário definir a carga de trabalho que se pretende analisar, pois em um ambiente distribuído há diferentes tipos de carga (Calzarossa et al., 2000), (Arlitt \& Jin, 1999). Para um servidor, por exemplo, a carga são as requisições HTTP vindas dos clientes ou ainda requisições de uma única sessão de um cliente. Já para uma máquina cliente, a carga apresentada são os cliques dados pelo usuário e as respostas dos servidores web. Os pacotes que circulam na rede, são considerados como uma carga para ela.

Além disso, é importante definir o nível de detalhamento empregado na descrição da carga de trabalho de um sistema, além de identificar seus componentes básicos, de modo que essa seja generalizada (Menascé, 2003), (Menascé \& Almeida, 2001).

Finalmente, os parâmetros que caracterizam cada componente da carga de trabalho, também precisam ser determinados. Por exemplo, os que caracterizam a intensidade da carga (taxa de chegada, número de clientes) e os que se referem à demanda de serviço colocada sobre o sistema (tempo de CPU, de I/O).

Após os parâmetros serem determinados, os dados devem ser coletados. Em sistemas muito complexos como a Web, a coleta de dados pode se tornar demorada e trabalhosa. Assim, para diminuir os efeitos da heterogeneidade da carga, esta pode ser dividida em classes com características equivalentes.

\subsubsection{Partição da Carga de Trabalho}

A carga de trabalho da Web pode ser dividida utilizando-se alguns critérios. O consumo de recursos do sistema é um deles, sendo possível dividir as requisições HTTP conforme seu consumo esperado de CPU e I/O. A origem geográfica das requisições que chegam a um servidor, também é outro critério, podendo para isso, serem analisados os endereços IPs dos clientes.

Outro critério interessante é a classificação da carga baseada nos tipos ou tamanhos dos objetos solicitados. Na Web, há requisições desde texto ou páginas HTML a imagens, áudio, vídeo e páginas dinâmicas. A carga de trabalho também pode ser dividida em classes segundo o tipo de aplicação que a originou, tal como um acesso a banco de dados ou uma sessão ftp. Diferentes aplicações impõe diferentes demandas sobre o sistema e conseqüentemente, tráfego variado. 
Enfim, podem ser propostos inúmeros critérios de classificação, cabendo ao analista identificar e implementar aqueles que sejam significativos para o estudo em questão.

\subsection{Considerações Finais}

Neste capítulo, foram abordados inicialmente a infra-estrutura da Internet e particularmente os protocolos TCP/IP, os quais são a base de toda a estrutura de comunicação na rede. Foi também apresentado um panorama geral da Web sendo discutida sua organização atual, como plataforma de comunicação de clientes e servidores. Esses assuntos são considerados de grande importância, já que foram a base de estudo do assunto desta proposta de trabalho.

O funcionamento do protocolo mais importante para acesso aos servidores web, o HTTP, foi estudado para melhor compreensão do comportamento da Web. Também foi estudado o uso de sessões HTTP na Web, com o objetivo de se ter um entendimento inicial, para o desenvolvimento da proposta deste trabalho.

No próximo capítulo são abordados os problemas e limitações do modelo atual de serviços da Internet e a necessidade da introdução de qualidade de serviço na mesma. É discutido também a provisão de uma QoS diferenciada em nível de aplicação, particularmente nos servidores web. 


\section{Qualidade de Serviço}

\subsection{Considerações Iniciais}

Neste capítulo são abordados os problemas atuais da Internet. Além disso, é verificado como a noção de qualidade de serviço pode tornar a Internet mais eficiente. A abordagem de serviços diferenciados sobre redes IP e a viabilidade de seu emprego em nível de aplicação, particularmente em servidores web, são destacados.

\subsection{Limitações da Internet Atual}

Um grande aumento no tráfego da Internet foi notado nos últimos anos. Enquanto ele se mantém inferior à capacidade da rede, todo o trabalho do protocolo IP é realizado eficientemente, porém, em fases de congestionamento, ocorrem atrasos na entrega dos pacotes e perda de dados na rede (Vasiliou, 2000).

Desde a criação das redes IPs, os elementos extremos da rede (hosts) são tratados como complexos e os elementos internos (roteadores) como sendo mais simples. A única tarefa dos roteadores era fazer a verificação dos endereços IPs dos datagramas em uma tabela de rotas, para determinar qual o próximo "salto"(hop) a ser dado (Stardust, 1999b).

Para a transmissão de dados provenientes de e-mail, transferência de arquivos e navegação na Web, essa técnica é suficiente, mas, se torna inadequada para os novos tipos de aplicações encontradas na Internet. Para aplicações multimídia, por exemplo, é necessária uma grande largura de banda, suportando somente pequenas perdas de pacotes. Para tele- 
fonia sobre IP, são exigidos requisitos de temporização para que a comunicação seja viável (Stardust, 1999b), (Cisco, 2005). Na transferência de arquivos, é necessário uma certa largura de banda não podendo tolerar a perda de nenhum bit de informação. Há aplicações como video-conferência e transmissão de rádio e TV via Web que utilizam-se de um serviço multicast. A tecnologia multicast é a base de um serviço de rede no qual um único fluxo de dados, proveniente de uma determinada fonte, pode ser enviado simultaneamente para diversos receptores interessados. Ao longo do trajeto, a própria infra-estrutura de rede replica o fluxo de dados, quando necessário, para todos os receptores que registraram interesse em receber estes dados.

Além disso, a Web tem se tornado uma plataforma de negócios, exigindo alta confiabilidade e disponibilidade do meio de transmissão, cujos usuários estão dispostos a pagar mais por um serviço mais previsível e de melhor qualidade (Xiao \& Ni, 1999).

O problema da Internet poderia parecer de largura de banda, porém, dotar a rede da maior capacidade possível como solução, além de economicamente inviável, não é a solução adequada para alguns casos, pois para algumas aplicações o ponto crítico não está na largura de banda disponível, mas sim na latência de transmissão.

Sendo assim, faz-se necessário realizar um gerenciamento da largura de banda disponível, diferenciando o tráfego que passa pelos elementos internos da rede e, dessa forma, fornecer classes ou níveis de serviço diferenciados aos usuários e aplicações (Cisco, 2005), (Xiao \& Ni, 1999).

\subsection{Conceitos Básicos de QoS}

Fornecer a um elemento da rede a garantia de que seus requisitos de tráfego e serviço serão satisfeitos é a principal função da Qualidade de Serviço (QoS) (Stardust, 1999b). Essa garantia está relacionada com a provisão de baixos delay (atraso de entrega) e perdas de pacotes para certos tipos de aplicações ou tráfego (Zhao et al., 1999).

Conforme a demanda das aplicações, o mecanismo de QoS administra a largura de banda existente na rede. Será reservada uma parte da largura de banda para as aplicações de mais alta prioridade, porém, sempre garantindo que as aplicações menos prioritárias não sejam anuladas.

A QoS é completamente obtida somente quando todas as camadas e elementos da rede possuem uma qualidade se serviço. Qualquer garantia de QoS será tão forte quanto o mais frágil elemento do caminho da transmissão de dados na rede (Stardust, 1999b). 
Duas características importantes dentro do tema de QoS são identificados: garantia de desempenho e diferenciação de serviços (Zhao et al., 1999). A primeira característica está relacionada com o gerenciamento de largura de banda, perda de pacotes, atraso e jitter (variação do atraso). A diferenciação de serviços está relacionada com o fornecimento de níveis de QoS distintos para diferentes aplicações.

A QoS pode ser absoluta ou relativa. Uma especificação de QoS em termos absolutos fornece métricas a serem cumpridas, relacionadas, em geral, ao atraso ou perda de pacotes. Já a QoS relativa, faz diferenciação de serviços, garantindo que uma aplicação em uma classe de mais alta prioridade nunca receberá um serviço pior que o de qualquer classe inferior (Zhao et al., 1999).

\subsubsection{Caracterização do Tráfego}

As demandas de QoS impostas à rede são fortemente influenciadas pelo tráfego gerado pelas aplicações, que pode ser caracterizado quanto à previsibilidade da taxa de dados e à sensibilidade ao atraso de entrega e jitter (Stardust, 1999b), (Magalhães \& Cardozo, 1999).

Em relação à previsibilidade, o tráfego pode ser:

- Tráfego de fluxo contínuo (stream). Típico de aplicações que geram mídia contínua, como áudio e vídeo. A entrega de dados é feita a uma taxa relativamente constante (CBR - Constant Bit Rate).

- Tráfego em rajadas. Característico de aplicações como transferência de arquivos e interações cliente-servidor. Os blocos de dados são entregues de forma imprevisível, a uma taxa de dados variável (VBR - Variable Bit Rate), podendo utilizar toda a largura de banda caso não seja utilizado algum tipo de controle.

Segundo a tolerância ao atraso e jitter, o tráfego pode ser dividido em cinco categorias:

- Tráfego assíncrono. Também chamado de "elástico". Não possui restrições temporais e aceita bem o serviço de melhor esforço. São consideradas dessa categoria, aplicações como ftp e e-mail.

- Tráfego síncrono. Possui restrições temporais, porém, as variações observadas podem ser compensadas através de esquemas de sincronização no receptor. O tráfego gerado por aplicações de áudio e vídeo sob demanda são incluídas nessa categoria. 
- Tráfego interativo. Para que a interação na comunicação não seja comprometida, são estipulados valores máximos ao atraso e jitter. Aplicações de video-conferência e telefonia sobre IP estão nessa categoria.

- Tráfego isócrono. Tráfego sensível ao tempo, sendo que altos atrasos e jitter comprometem a qualidade da informação transmitida podendo tornar a aplicação inutilizada. Característico de aplicações que podem ter um baixo atraso, como difusão de rádio e TV em redes comutadas por pacotes.

- Missão-crítica. Atraso e jitter que ultrapassam certos limites, comprometem a funcionalidade de aplicações como de automação industrial, de tele-comando e de telesupervisão (Magalhães \& Cardozo, 1999).

\subsection{Arquitetura para QoS}

Qualidade de Serviço na Internet tem sido um assunto bastante pesquisado nos últimos anos, havendo propostas com várias abordagens com o intuito de alcançar este objetivo (Wen \& Lu, 2002). Duas arquiteturas para QoS na Internet merecem destaque: Serviços Integrados (IntServ) e Serviços Diferenciados (DiffServ) (Stardust, 1999a), (Zhao et al., 1999).

\subsubsection{Serviços Integrados}

A arquitetura de Serviços Integrados (IntServ) foi a primeira solução proposta de QoS na Internet. Definida na RFC 1633 (Braden et al., 1994), seu objetivo é fornecer um serviço mais próximo possível da abstração de circuitos virtuais, em uma rede comutada por pacotes como a Internet, suprindo necessidades requeridas por determinados tipos de tráfego, por exemplo, na transmissão de áudio e vídeo.

São definidas duas classes de serviço na arquitetura de IntServ além do tradicional modelo de melhor esforço encontrado nas redes IP, Serviço Garantido e Serviço de Carga Controlada.

\section{Serviço Garantido (Guaranteed Service)}

Garante a disponibilidade de largura de banda e fornece um limite superior para o atraso de comunicação. As aplicações que possuem requisitos estritos de tempo real podem 
utilizar esse serviço para conseguirem um alto nível de QoS na Internet. Este serviço está especificado na RFC 2212 (Shenker et al., 1997).

\section{Serviço de Carga Controlada (Controlled-Load Service)}

O serviço oferecido equivale ao modelo de melhor esforço, com quase nenhuma perda de pacotes ou atraso, para uma rede com pouco tráfego. Em situações de sobrecarga, a largura de banda será compartilhada entre múltiplos fluxos, garantindo um melhor serviço do que o normal. Porém, não é garantido um atraso máximo, apenas um limiar probabilístico, assim como, não é assegurado que não haverá perda de pacotes. Este serviço é especificado na RFC 2211 (Wroclawski, 1997).

\section{Protocolo RSVP}

Para a arquitetura IntServ, antes da transmissão de dados ser iniciada, as aplicações devem encontrar o caminho para o transporte de dados até o receptor que melhor satisfaça suas exigências de QoS, reservando os recursos necessários ao longo desse caminho (Xiao \& Ni, 1999). Essa reserva de caminhos e recursos é realizada por meio de um protocolo chamado RSVP (Resource Reservation Protocol) (Stallings, 2002).

O protocolo RSVP é considerado uma das soluções mais complexas em suporte ao fornecimento de QoS (Stardust, 1999a). O RSVP é um protocolo de controle e sinalização que atua na camada de rede. Ele é usado por aplicações para reservar recursos ao longo da rede, sendo especificado na RFC 2205 (Braden et al., 1997).

Deve-se ressaltar que embora pertença à camada de rede, o RSVP não é um protocolo de roteamento, ele transporta apenas informações de controle e sinalização relacionados com a reserva de recursos na rede. Toda essa informação permanece armazenada nos roteadores durante um certo tempo (abordagem Soft State), sendo necessário renová-las periodicamente, o que é de responsabilidade dos hosts finais (end hosts).

As reservas de recursos (largura de banda, atraso e jitter), são iniciadas pelo receptor e são utilizadas para fluxos unidirecionais, servindo tanto para transmissão unicast como multicast.

O RSVP permite fazer o gerenciamento de fluxo em uma granulosidade bem fina, conseguindo-se com isso, altos níveis de QoS na Internet (Stardust, 1999a). Porém, grandes problemas de gerenciamento e escalabilidade são encontrados no RSVP (Vasiliou, 2000), pois é necessário que todos roteadores ao longo do caminho dêem suporte a RSVP, mantendo 
informações de estado e escalonando pacotes para cada fluxo para se conseguir QoS. Porém, as reservas feitas são independentes do protocolo de roteamento, podendo o tráfego passar por roteadores não habilitados para RSVP, onde será usado o modelo de melhor esforço e portanto, não sendo possível assegurar a QoS nesse trecho do caminho.

Na Internet, o gerenciamento de informações para milhares de fluxos concorrentes que podem passar por um mesmo roteador parece quase impossível, mesmo porque a memória e a capacidade de processamento nos roteadores são limitadas.

Com o RSVP, uma complexidade significativa é colocada no núcleo da Internet, rompendo o seu modelo tradicional de serviços, que sempre procurou levar a complexidade para os hosts finais mantendo a simplicidade da rede (Stardust, 1999a).

Portanto, a abordagem de serviços integrados, é melhor empregada em um ambiente de rede local, fornecendo uma QoS para aplicações de um domínio.

\subsubsection{Serviços Diferenciados}

A arquitetura de Serviços Diferenciados (DiffServ), definida na RFC 2475 (Blake et al., 1998), teve seu desenvolvimento motivado por problemas de escalabilidade da arquitetura de IntServ e a dificuldade dessa arquitetura ser implantada em uma rede com as proporções da Internet.

O DiffServ é baseado na idéia de agregação de fluxos em classes de serviço, o que permite oferecer diferenciação de serviços para grandes agregados de tráfegos locais (Magalhães \& Cardozo, 1999), ao contrário do modelo IntServ que dá garantias de desempenho fim-a-fim para fluxos individuais (Vasiliou, 2000).

Baseado em um esquema de prioridades relativas, o modelo Diffserv garante um melhor tratamento de tráfego gerado por aplicações com um certo nível de prioridade do que para qualquer outra com prioridade inferior (Xiao \& Ni, 1999). Para isso, é feita uma classificação de pacotes e com base nessa, os pacotes são tratados de maneira diferenciada no interior da rede.

A marcação dos pacotes é feita nos pontos de ingresso na rede (hosts finais e roteadores de borda) mantendo a complexidade na fronteira da rede, princípio básico do projeto da Internet, ao contrário do modelo IntServ, que exige complexidade por todo percurso da entrega de dados.

Os pacotes são classificados modificando-se a definição do layout do octeto Type-ofService do cabeçalho do protocolo IPv4 (ou o campo Traffic Class do IPv6), que passa a ser 
chamado de campo DS (Differentiated Services), definida na RFC 2474 (Nichols et al., 1998). Os seis primeiros bits do campo DS passam a ser chamados de campo DSCP (Differentiated Services Codepoint) e são usados para a especificação de como o encaminhamento de pacotes em cada roteador será tratado. Esse mecanismo de priorização é chamado de PHB (Per-hop Behavior) pelo qual permite agregar fluxos gerados por diferentes aplicações, definindo-os como uma classe de serviço (Magalhães \& Cardozo, 1999).

Utilizando um campo do próprio datagrama IP para a marcação de pacotes, não há necessidade de um protocolo para o DiffServ, sendo somente preciso que o roteador examine o campo DSCP de cada pacote para distinguí-los entre um certo número de classes de serviço pré-definidas, dando à eles o tratamento conveniente conforme classe a qual pertencem.

Atualmente são definidas na arquitetura de serviços diferenciados duas classes de serviços principais, Encaminhamento Expresso e Encaminhamento Garantido, que são abordadas a seguir (Kilkki, 1999).

\section{Encaminhamento Expresso}

O serviço Encaminhamento Expresso (Expedited Forwarding - EF) ou Premium Service fornece garantias de QoS absoluta, com baixos valores de perda, atraso e jitter.

Esse serviço permite adaptar o modelo de Serviço Garantido da arquitetura Intserv à arquitetura DiffServ oferecendo o equivalente a uma linha privada virtual com largura de banda fixa entre dois hosts, podendo ser utilizado por aplicações de telefonia sobre IP, vídeo-conferência e para a criação de linhas dedicadas em redes privadas virtuais (VPNs). Ele está definido na RFC 2598 (Jacobson et al., 1998).

A vantagem desse serviço em relação ao serviço equivalente da arquitetura IntServ é a simplicidade da sua implementação, pois nenhuma informação relativa a fluxos é necessária ser mantida nos roteadores, os quais devem escalonar o tráfego com a finalidade de manter as filas de saída descongestionadas, para que o tráfego permaneça o menor tempo possível no equipamento (Magalhães \& Cardozo, 1999).

Com o serviço de Encaminhamento Expresso, os pacotes desta classe são colocados em uma fila de maior prioridade do que a do tráfego de melhor esforço e sempre são os primeiros a serem encaminhados. Além disso, sempre é evitado que os pacotes com esse contrato sejam descartados, o que não ocorre com aqueles que não possuem esse contrato. 


\section{Encaminhamento Garantido}

A classe de serviço Encaminhamento Garantido (Assured Forwarding - AF), também chamado de Assured Service, está definida na RFC 2597 (Heinanen et al., 1999). Ela oferece um serviço mais confiável do que o de melhor esforço, porém, não dá todas as garantias de QoS que o Encaminhamento Expresso provê. Além disso, é garantido um tratamento preferencial ao tráfego, mas sem oferecer limites superiores para o atraso e jitter.

Esse serviço oferece uma melhor QoS para agregados de tráfego que consiste de rajadas de curta duração com destinos diferentes (Stoika \& Zhang, 1998), onde o tráfego é dividido em classes com diferentes níveis de precedência de descarte. Em situações de sobrecarga na rede os pacotes são descartados com base na prioridade de descarte, pela qual, os pacotes pertencentes ao serviço de melhor esforço são os primeiros a serem descartados e, só então, passa-se para os pacotes associados ao serviço de encaminhamento garantido

Os serviços das arquiteturas de Serviços Integrados e Diferenciados podem ter uma relação útil quando são usados em conjunto para oferecimento de QoS, onde o Serviço Garantido (IntServ) pode ser mapeado para o Serviço de Encaminhamento Expresso (DiffServ) e o Serviço de Carga Controlada (IntServ) para o Serviço de Encaminhamento Garantido (DiffServ).

\section{Service Level Agreements}

Service Level Agreement (SLA) é o "acordo de serviço"entre as partes da comunicação para que um usuário se torne habilitado a receber serviços diferenciados de um provedor. Nesse acordo, está definida a classe de serviço contratada e sua respectiva quantia de tráfego suportada.

Um SLA quando negociado em bases mensais ou anuais é dito como estático, e quando negociado para requisição de serviços de QoS sob demanda utilizando um protocolo de sinalização (como o RSVP), é considerado como dinâmico.

As políticas de QoS podem ser aplicadas baseadas em números de portas, data e hora, endereços de origem e destino, ou outras informações que estejam contidas no tráfego (Stardust, 1999b). Além disso, podem ser especificados procedimentos de tarifação e cobrança, serviços de criptografia e autenticação, procedimentos de renegociação dos parâmetros do SLA, entre outros (Vasiliou, 2000).

Um tráfego não receberá nenhum tipo de garantia de QoS fora do perfil contratado. Assim, ao chegar ao próximo ponto de ingresso (ingress point) em outro domínio, o domínio 
de origem é responsável pelo policiamento do tráfego enviado (policing) nos pontos de saída (egress points).

Para tanto, o campo DS do pacote poderá ser remarcado quando deixar um domínio e seguir para outro conforme o SLA estabelecido entre os dois domínios, porém, tem-se como ideal, que o tráfego mantenha o mesmo nível de QoS durante todo o caminho de transmissão, da origem ao destino, o que nem sempre é possível.

\subsubsection{Protocolo MPLS}

O protocolo MPLS (Multi-Protocol Label Switching), especificado na RFC 3031 (Rosen et al., 2001) é uma abordagem alternativa aos serviços diferenciados, e que ultimamente tem sido alvo de atenção, devido a sua simplicidade e eficiência.

Com o MPLS, os pacotes são marcados nos pontos de ingresso na rede e desmarcados nos pontos de saída para que o roteamento seja realizado. O próximo hop a ser dado é verificado conforme o rótulo (label) colocado no pacote.

A marcação de pacotes utilizada pelo MPLS portanto, é efetivamente para o roteamento de pacotes, ao contrário do DiffServ, em que a utiliza como forma de atribuir prioridade aos pacotes dentro dos roteadores. O rótulo de um pacote MPLS determina o caminho que ele deverá seguir na rede, o que permite que canais (pipes) com largura de banda fixa, sejam estabelecidos, tais como circuitos virtuais de uma rede ATM ou Frame Relay.

O funcionamento do protocolo MPLS é feito integralmente nos roteadores, sem afetar os elementos finais. Ele pode funcionar sobre diferentes tipos de protocolos além do IP, pois opera entre as camadas de rede e enlace (Vasiliou, 2000).

Enfim, a utilização dessas arquiteturas de provisão de QoS em conjunto parece bastante promissora. É improvável que na prática, essas soluções apresentadas (RSVP, DiffServ, MPLS) sejam utilizadas separadamente para fornecer QoS fim-a-fim. De modo geral, tem-se uma combinação dessas arquiteturas durante o percurso entre o emissor e o receptor, para que possa ser obtido o melhor de cada uma delas (Stardust, 1999a). 


\subsection{Serviços Diferenciados em Nivel de Aplicação}

Como já comentado, é necessária a cooperação de todos os elementos do sistema para o fornecimento de QoS e principalmente dos hosts finais, já que estes que fazem o atendimento aos usuários.

Todos os esforços realizados para o oferecimento de QoS na rede podem ser anulados quando um servidor web não esteja preparado nesse sentido, pois esse servidor irá atender igualmente todas as solicitações que receber, ignorando as prioridades das mesmas. Infelizmente, a grande maioria dos servidores atuais ainda tratam todas as solicitações igualmente, seguindo uma disciplina FCFS (First-Come First-Served), o que muitas vezes pode prejudicar fortemente o sistema. Desse modo, não será possível haver uma provisão de QoS na Web caso não se considere o servidor web como um elemento essencial na comunicação.

Esse é um dos assuntos mais importantes a ser tratado relacionado à Internet, pois a Web tem sido fortemente utilizada como um meio para a condução de negócios, cujo elemento central desse cenário é o servidor web. Portanto, serão exigidos desse elemento, requisitos de qualidade de serviço, disponibilidade, confiabilidade e segurança (Vasiliou \& Lutfiyya, 2000).

\subsection{Considerações Finais}

Neste capítulo, foram abordados os problemas verificados atualmente na Internet como forma de motivação para se ter um fornecimento de serviço diferenciado na mesma. Foi apresentada uma visão geral da área de qualidade de serviço, onde seus conceitos básicos foram abordados, sendo verificado que as características de QoS empregadas, permite maior eficiência no atendimento ao tráfego da Internet.

Foram destacadas as arquiteturas de Serviços Integrados (IntServ) e Serviços Diferenciados (DiffServ) e suas respectivas classes de serviços. Foi também apresentada uma abordagem alternativa aos Serviços Diferenciados, o MPLS.

Finalmente, foi mostrado como a possibilidade de utilização de QoS na Internet oferece suporte a novos tipos de aplicações, com níveis de serviço superiores aos do modelo atual de melhor esforço. Foi também mostrada a importância de se ter diferenciação de serviços em nível de aplicação, o que motiva a realização desta proposta de trabalho, otimizando o modelo de servidor SWDS com a introdução da característica de reconhecimento de sessões HTTP. 
O próximo capítulo será dedicado à apresentação do modelo de servidor web com diferenciação de serviços (SWDS), proposto por Teixeira (2004), no qual esta dissertação de mestrado será baseada. 



\section{Servidor Web com Diferenciação de Serviços (SWDS)}

\subsection{Considerações Iniciais}

Com as novas aplicações existentes na Internet, há uma grande necessidade de se ter características de diferenciação de serviços nos servidores web, já que são estes elementos finais que atendem às requisições.

Neste capítulo é apresentado o modelo para um Servidor Web com Diferenciação de Serviços desenvolvido por Teixeira (2004) sendo descrito seus principais componentes. É também dada uma visão geral dos algoritmos de controle de admissão e diferenciação de serviços propostos para o modelo. Finalmente, são discutidos alguns cenários de uso para serviços diferenciados.

\subsection{Modelo do Servidor Web com Diferenciação de Serviços}

O modelo para um Servidor Web com Diferenciação de Serviços (SWDS) proposto por (Teixeira, 2004), apresenta uma arquitetura de servidor web, cujo objetivo é fornecer aos seus clientes, serviços diferenciados conforme suas necessidades e requisitos de QoS previamente acertados.

A arquitetura do servidor SWDS compõe-se dos seguintes módulos, conforme exibidos na Figura 4.1: 
- Classificador. Este módulo é responsável pelo recebimento das requisições que chegam ao sistema. Ele faz a divisão das requisições em classes de serviço baseando-se em critérios pré-estabelecidos. Após sua classificação, a nova requisição passa para o sistema e conforme a sua categoria estabelecida, receberá um determinado tratamento.

- Controle de Admissão. Após serem classificadas, as requisições são recebidas por esse elemento. Ele faz o gerenciamento da aceitação das requisições pelo servidor. Para isso, são consideradas as políticas de atendimento vigentes e as informações da carga de trabalho do sistema. Uma requisição poderá ser rejeitada (Descarte) se o sistema estiver sobrecarregado, ou então ser aceita em uma classe de prioridade inferior, quando suas exigências de qualidade de serviço forem revistas (Negociação).

- Cluster. As requisições admitidas no sistema são atribuídas a um dos nós do cluster de servidores web. O atendimento das requisições é realizado conforme o algoritmo de escalonamento ou diferenciação de serviços vigente. Após ser concluído o processamento da aplicação, os resultados são enviados ao cliente.

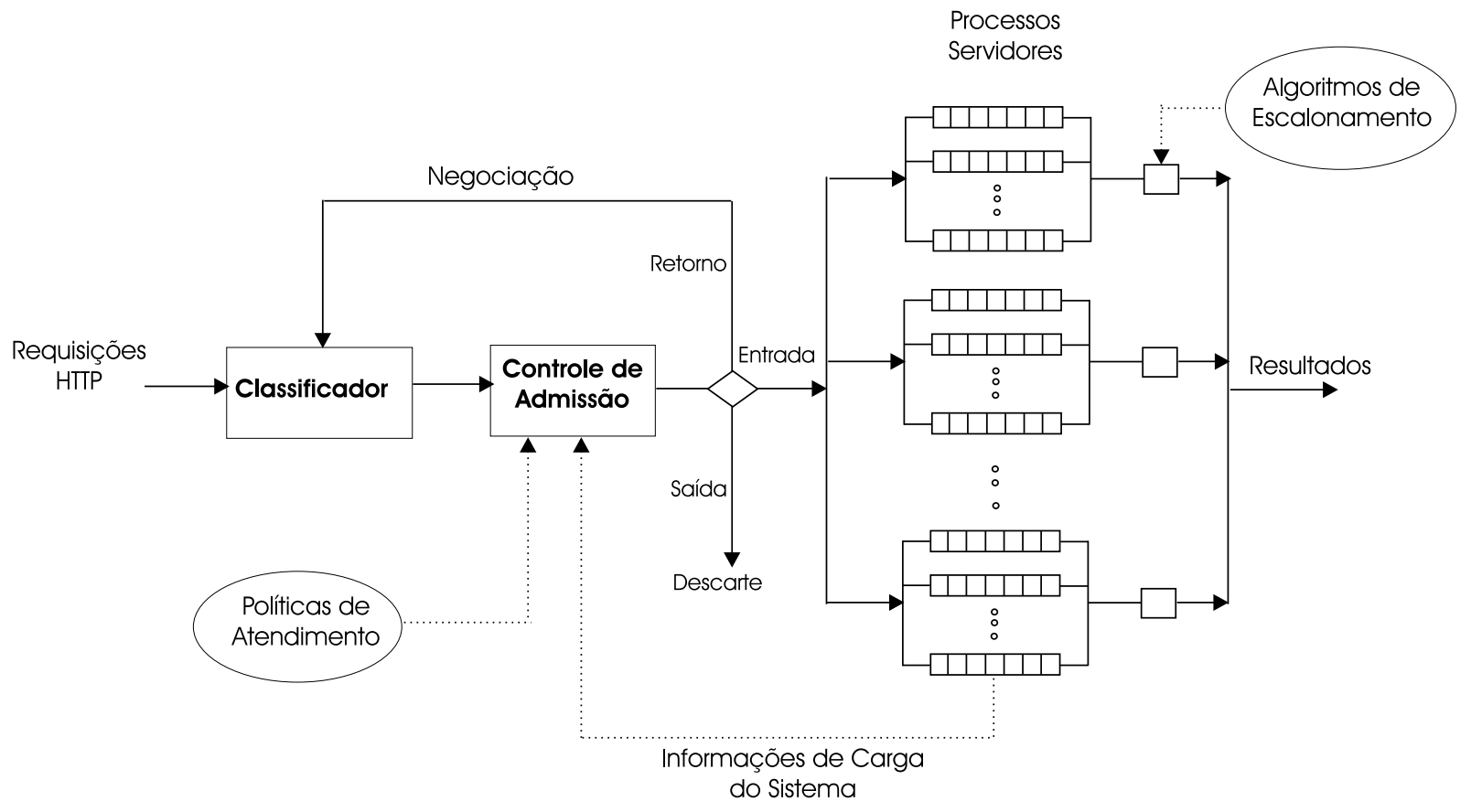

Figura 4.1: Servidor Web com Diferenciação de Serviços (SWDS) (Teixeira, 2004)

Para o modelo SWDS, não é suposta nenhuma plataforma de hardware ou sistema operacional específicos. Os nós do cluster são considerados como servidores web convencionais, compostos de CPU, disco e interface de rede. Com o objetivo de atender as diferentes classes de serviço, múltiplas filas de prioridade são atribuidas à cada nó. 
Apesar de ser considerado formado por servidores web, o cluster do modelo pode ser abstraído para processos ou até mesmo CPUs em um computador paralelo, pois não há exigências de que a arquitetura seja necessariamente formada por máquinas dispostas em um sistema distribuído.

O modelo SWDS foi validado por simulações dirigidas por traces por se tratar de uma técnica adequada e devido à larga experiência do Grupo de Sistemas Distribuídos e Programação Concorrente no uso de modelagem e simulação. Para isso, foi utilizado o simulador SimPack (Cubert \& Fishwick, 1995) e logs de acesso a servidores web reais, coletados durante a Copa do mundo 98, na França, para a geração de carga. Esse log constitui um dos poucos disponíveis publicamente, sendo de tamanho e conteudo adequados ao trabalho.

O modelo de servidor SWDS integra características de QoS às arquiteturas de servidores tradicionais e, portanto, constitui uma proposta inovadora para o fornecimento de serviços diferenciados em servidores web. Destaca-se sua flexibilidade devida aos vários tipos de mecanismos de controle de admissão e diferenciação de serviços.

\subsection{Controle de Admissão}

Toda a diferenciação de serviços realizada no servidor será comprometida caso este fique sobrecarregado, não permitindo se conseguir atingir os níveis de QoS pretendidos. Portanto, o principal objetivo do módulo de controle de admissão do servidor SWDS é fazer com que a carga do sistema seja sempre mantida dentro de níveis aceitáveis. Para isso, são consideradas nesse módulo, as informações da carga do sistema, além das políticas de atendimento.

O Controle de Admissão do modelo foi projetado de modo que possa ser ampliado futuramente, conforme a necessidade, através de novas métricas e novos algoritmos de controle de admissão.

Os componentes descritos a seguir, compõem a arquitetura do Controle de Admissão e podem ser visualizados na Figura 4.2:

- Coleta de informações. Este módulo recebe as informações atualizadas da carga do sistema, que servem como base para a tomada de decisão.

- Área de variáveis globais. Mantém informações sobre o estado do sistema e as métricas que são importantes para o Controle de Admissão. Na situação atual do modelo, as 
métricas usadas são o tamanho das filas do cluster, o tempo de resposta das requisições e a utilização do sistema.

- Mecanismos de controle. São os mecanismos de controle de admissão implementados para controlar a sobrecarga do sistema.

- Área de Buffers. Onde estão localizados buffers e podem ser utilizados, por exemplo, para limitar o número de clientes de uma classe presente no servidor, ou ainda, limitar o número de clientes em uma fila.

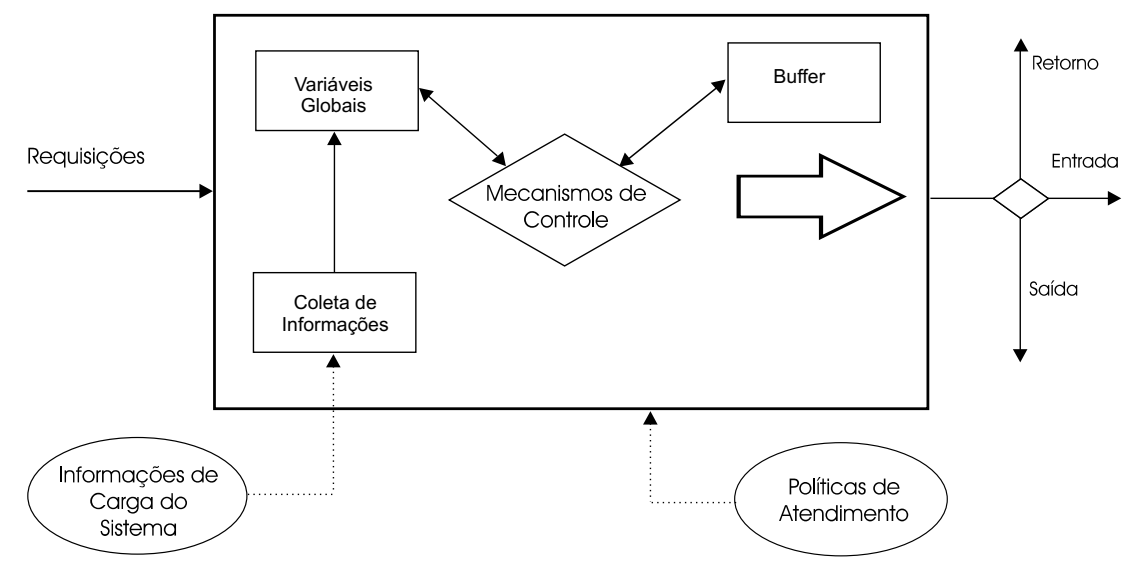

Figura 4.2: Módulo de Controle de Admissão (Teixeira, 2004)

\subsubsection{Mecanismos de Controle de Admissão}

Os mecanismos de Controle de Admissão determinam o comportamento adotado pelo servidor SWDS, quando novas solicitações são impostas sobre o mesmo.

Foram implementados três mecanismos de controle de sobrecarga no SWDS por Teixeira (2004), descritos a seguir.

\section{Tamanho das Filas}

Este mecanismo, impõe um tamanho máximo para as filas dos servidores do cluster, recusando novas requisições quando esse limite for atingido. Caso este seja atingido, não serão aceitas novas requisições, independente da classe a qual pertence.

No entanto, este mecanismo não oferecem garantias rígidas de QoS aos clientes. Sua principal contribuição é, portanto, diminuir a carga do sistema e conseqüentemente o tempo 
de atendimento das requisições. Desse modo, é recomendada a sua utilização em conjunto com outros mecanismos.

\section{Tempo de Resposta}

Tenta manter o tempo de resposta abaixo de um certo limiar, utilizando buffers independentes para cada classe de serviço, que controlam o número de clientes presentes no servidor. As requisições de alta prioridade são recusadas somente em situações críticas e as de baixa prioridade apenas quando a carga estiver abaixo do limiar especificado.

Com este mecanismo, evita-se que o tempo de resposta apresente picos devido aos aumentos na carga de trabalho, conseguindo-se uma maior estabilidade no sistema.

\section{Utilização do Sistema}

O mecanismo emprega uma média exponencialmente ponderada da utilização do cluster para o controle de admissão, a qual pode ser ajustada conforme valores atuais ou o histórico da carga do sistema.

Este mecanismo consegue manter a utilização do servidor SWDS, dentro do limiar especificado de forma rigorosa, o que permite oferecer um tratamento mais justo a todas as classes de requisições, fazendo com que solicitações que não poderão ser atendidas, não sejam aceitas no sistema.

\subsection{Mecanismos de Diferenciação de Serviços}

Os algoritmos de diferenciação de serviço especificam a forma de compartilhamento do cluster de servidores web entre as classes de serviço. Eles determinam qual categoria de clientes terá preferência no atendimento, realizando a diferenciação de serviços propriamente dita.

Foram implementados três algoritmos de diferenciação de serviços no modelo, os quais correspondem a duas abordagens distintas para o fornecimento de serviços diferenciados: enfileiramento baseado em classes e escalonamento baseado em prioridades. 


\subsubsection{Reserva de Recursos}

Este algoritmo de diferenciação de serviço faz a subdivisão do cluster de servidores web em partições. É feita então uma associação dessas partições às classes de serviço. Com isso, uma parcela da capacidade de processamento do servidor SWDS é reservada para cada classe de requisições, desse modo, faz-se o isolamento de desempenho entre as classes, evitando a interferência no comportamento entre elas.

Contudo, esse particionamento estático do cluster foi considerado pouco flexível em um ambiente altamente dinâmico como a Web, pois os recursos destinados a uma classe de serviço podem ficar sobrecarregados enquanto os de outra classe estão subtilizados.

\subsubsection{Mecanismo de Prioridades Rigoroso}

Neste algoritmo de diferenciação de serviço, prioridades são estabelecidas nas filas do cluster, para que as requisições sejam atendidas conforme uma disciplina de prioridades rígida, desse modo, as requisições de mais alta prioridade serão sempre atendidas em primeiro lugar.

Em diferentes configurações de carga de trabalho e do servidor, este mecanismo consegue efetivamente fornecer serviços diferenciados aos clientes. Além disso, ele permite alcançar plena utilização dos recursos disponíveis, ao contrário da abordagem anterior. Entretanto, cuidados são necessários para que as requisições de alta prioridade não monopolizem o uso dos recursos do sistema, podendo ocorrer a negação de serviço às requisições de menor prioridade.

\subsubsection{Mecanismo de Prioridades Adaptativo}

Neste mecanismo, é determinado quão rigoroso será o esquema de prioridades empregado através do uso de um parâmetro de look-ahead nas filas do cluster. Com ele, evita-se os problemas de negação de serviço do mecanismo de prioridades rigoroso permitindo a capacidade de adaptação ao servidor SWDS.

Deste modo, o servidor pode ser ajustado para melhor responder a variações na carga de trabalho impostas ao sistema. Em um ambiente altamente mutável como a Web, essa característica torna-se bastante atrativa. Além disso, a diferenciação de serviços é realizada de forma distribuída, ao contrário de outras abordagens que dependem de um componente central para esse fim. Essa vantagem permite que a carga associada à diferenciação de serviços 
seja transferida para cada nó do cluster, aumentando a confiabilidade e a escalabilidade do sistema.

\subsection{Cenários de Utilização}

O fornecimento de serviços diferenciados em servidores web, tem se tornado fortemente necessário, pois, verifica-se atualmente, que o modelo de serviço de melhor esforço utilizado na Web, tornou-se inadequado e restritivo (Dovrolis \& Ramanathan, 1999). Além disso, reconhecer as diferenças entre os usuários, com o objetivo de fornecer-lhes serviços diferenciados conforme suas necessidades e até mesmo pelo qual podem pagar, torna-se cada vez mais importante (Arlitt, 2000).

O cenário mais propício e atual para se empregar serviço diferenciado é o de Comércio Eletrônico (Vallamsetty et al., 2003), (Liu et al., 2004), o qual é caracterizado pelo uso de sessões seguras e páginas dinâmicas. Há também, um alto nível de concorrência entre os usuários que, portanto, poderia ser dada preferência ao atendimento de clientes em processo de conclusão de uma compra, do que os que estejam apenas visitando o site. Porém, o atendimento ao usuários visitantes não deve ser menosprezado, pois estes poderão se tornar futuros compradores (Cherkasova \& Phaal, 2002), (Wei et al., 2003).

Outra possibilidade de cenário a ser aplicada QoS diferenciada seria os Provedores de Acesso à Internet, onde é encontrado um alto nível de concorrência entre os usuários, destacando-se o acesso a notícias e correio eletrônico via Web. Nessa situação, os usuários poderiam ser divididos em dois grupos, pagantes e não-pagantes, os quais teriam tratamentos diferenciados.

Outro cenário possível para o uso de serviços diferenciados na Web, é o Setor Acadêmico, no qual pode-se encontrar as mais variadas tarefas como, acesso a Web-mail, download de material didático, ambientes de ensino à distância, entre outros. Com os serviços diferenciados, torna-se possível, por exemplo, dar prioridade a tarefas consideradas como mais importantes ou, também, considerar as requisições de alunos de pós-graduação, professores e alunos de graduação, com prioridades dependentes.

Em outros cenários importantes relacionados a sites de empresas, bancos e serviços de download, poderiam ainda ser empregados os sistemas com serviços diferenciados.

Enfim, um acompanhamento do serviço fornecido é sempre necessário para muitas das aplicações atuais, que precisam de garantias de que esses serviços estejam dentro dos padrões de QoS desejados, permitindo um atendimento justo à todas as classes de usuários. 


\subsection{Considerações Finais}

Foi apresentada neste capítulo uma arquitetura para um Servidor Web com Diferenciação de Serviços, o SWDS, cujo objetivo é atender seus clientes com uma qualidade diferenciada, fornecendo a cada classe de serviço um tratamento condizente com suas características de demanda.

Foi também apresentada uma visão geral do módulo de Controle de Admissão que se mostra indispensável para o fornecimento de garantias de QoS aos clientes, cujos mecanismos de diferenciação de serviços tornaram possível o atendimento aos clientes de uma forma mais justa e eficiente.

Finalmente, foram comentados alguns cenários de aplicação de serviços diferenciados que se mostram como uma motivação para a otimização do modelo de servidor SWDS, que é a proposta deste trabalho de mestrado.

No capítulo seguinte faz-se um estudo sobre sessões HTTP e o método para a incorporação da característica de reconhecimento de sessões HTTP ao modelo SWDS é apresentado. 


\section{Capítulo}

\section{Reconhecimento de Sessões no SWDS}

\subsection{Considerações Iniciais}

No capítulo anterior foi apresentado o modelo de Servidor Web com Diferenciação de Serviços (SWDS) proposto em (Teixeira, 2004), o qual é considerado como o principal fundamento para o desenvolvimento deste trabalho. Foram descritos os módulos que compõem esse modelo: Classificador, Controle de Admissão e um Cluster de processos servidores, com especial atenção para o Controle de Admissão, já que este é considerado como o módulo de maior relevância para este projeto de mestrado.

Este capítulo faz um estudo sobre sessões HTTP. Para isso, foi tomado como base na caracterização de sessões do Log da Copa do Mundo de 1998, o trabalho de (Arlitt, 2000). As informações adquiridas no artigo estudado foram de grande valor para que traces do log considerado fossem utilizados como carga de trabalho para as simulações realizadas neste projeto.

Ainda neste capítulo, são descritas as modificações realizadas no SWDS para que a característica de reconhecimento de sessões pudesse ser incorporada ao modelo. Uma das modificações foi a incorporação de um novo componente, o módulo de Reconhecimento de Sessões.

Neste capítulo, também explica-se como a classificação de requisições da carga de trabalho foi realizada, para que o Controle de Admissão de Requisições se adequasse ao modelo SWDS com a nova característica de reconhecimento de sessões adquirida.

Por fim, faz-se uma explicação de como será a experimentação do modelo, com a nova 
característica e de qual metodologia será utilizada.

\subsection{Característica de Reconhecimento de Sessões}

Como mencionado anteriormente, o principal objetivo deste projeto é permitir que o modelo SWDS exibido na seção anterior, se torne capaz de reconhecer sessões HTTP (chamadas também de sessões web), já que em seu estado original, faz o tratamento somente de requisições de forma diferenciada, não sendo capaz de distinguir suas respectivas sessões.

Um conceito fundamental para este trabalho, baseado no estudo de (Arlitt, 2000), é a definição de uma Sessão Web. Portanto, considera-se como uma Sessão Web, uma sequência de requisições feitas por um único usuário final durante o acesso a um determinado site (Arlitt, 2000).

Outro conceito importante adquirido também em (Barford \& Crovella, 1999), é a consideração de tipos de arquivos requisitados pelos browsers. São definidos três tipos de arquivos:

- Arquivos Bases (Base Files): Página HTML que contém arquivos embutidos;

- Arquivos Embutidos (Embedded Files): Arquivos referenciados pelos arquivos bases. (Exemplo: Imagens);

- Arquivos Únicos (Single Files): São arquivos independentes. Não são considerados arquivos bases ou arquivos embutidos. (Exemplo: Arquivos compactados).

Considera-se, portanto, que uma sessão inicía-se com uma requisição de um arquivo base, ou seja, de uma página web pertencente à um site, feita por um usuário. Essa requisição pode ser gerada quando um usuário clicar em um link ou quando digitar uma URL em um browser.

A página web requisitada pelo usuário, geralmente contém vários arquivos embutidos, e para cada um, é gerada uma requisição ao servidor. Essas requisições podem ser enviadas separadamente ao servidor, sendo estabelecida uma conexão TCP para cada uma, ou por meio de uma única conexão TCP, método utilizado por browsers que utilizam-se do protocolo HTTP 1.1. Desse modo, a arquitetura do browser pode afetar o tempo entre as requisições de uma mesma sessão.

Portanto, quando o usuário faz uma requisição de uma página base, uma rajada de requisições é enviada ao servidor web, sendo que o tempo entre essas requisições se 
torna aproximadamente nulo. Esse tempo é denominado de Tempo Entre Requisições (InterRequest Time).

Porém, caso o usuário requisite uma próxima página web (Página Base), a sessão continua a existir para o servidor e o tempo ocioso entre as requisições dessas páginas bases é chamado de Tempo de Pensar do Usuário (User Think Time).

Os conceitos comentados nesta seção serviram de base para a criação de um módulo de reconhecimento de sessões para o modelo SWDS e também, para a geração da carga de trabalho utilizada nas simulações realizadas para avaliar o desempenho do modelo com a característica desenvolvida. Esses itens serão comentados nas seções a seguir.

\subsection{Módulo de Reconhecimento de Sessões no SDWS}

O modelo SWDS, como visto no capítulo anterior, possui três módulos, o Classificador, o Controle de Admissão e o Cluster de processos servidores. Para que a nova característica de reconhecimento de sessões pudesse ser adaptada ao modelo, um novo recurso foi criado, o módulo de Reconhecimento de Sessões.

O reconhecimento das sessões, logicamente, foi realizado antes que as requisições fossem classificadas, portanto, o novo módulo foi inserido estruturalmente, antes do módulo de classificação de sessões, como pode ser visto na Figura 5.1.

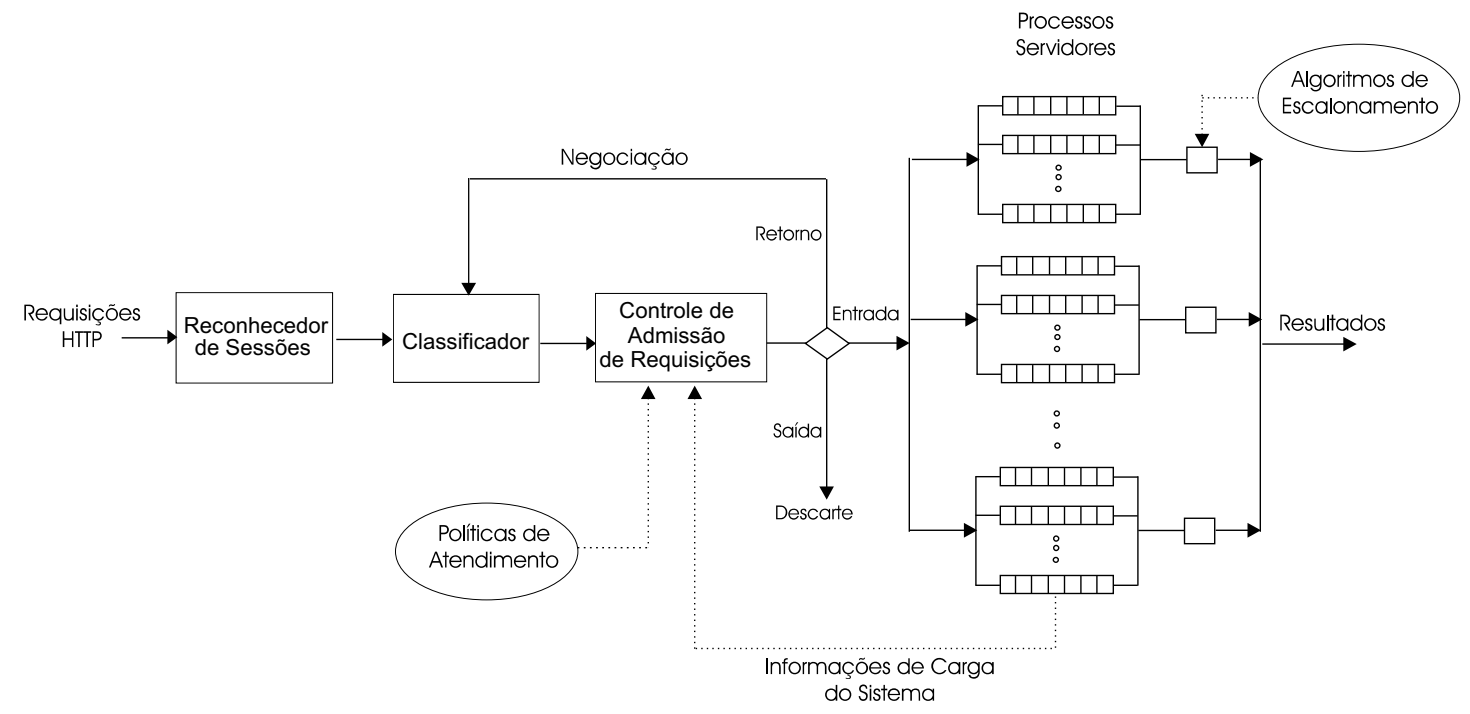

Figura 5.1: Modelo SWDS com o novo módulo de reconhecimento de sessões

O principal objetivo desse novo módulo, é reconhecer à qual sessão pertence uma requisição chegada ao sistema. 


\subsubsection{Método para reconhecimento de sessões}

O novo módulo de reconhecimento de sessões inserido ao modelo SWDS utiliza informações de um Buffer de Sessões Ativas para certificar-se de quais sessões estão ativas no sistema em um determinado momento.

No buffer são inseridos os identificadores das sessões que se apresentam ativas no sistema. Ao chegar uma nova requisição ao sistema, é verificado o número IP de sua sessão, se este número IP estiver presente no buffer de sessões ativas, o sistema considera que a sessão dessa nova requisição se apresenta ativa. Caso o número de sua sessão não seja encontrada neste buffer, o identificador de sua sessão será inserido à ele.

O Buffer de Sessões Ativas foi construído dando suporte a uma quantidade máxima de armazenamento de sessões, coerente com a capacidade das filas do cluster, pois o sistema conseguirá atender, em última hipótese, o número de requisições máximo admitido pelas filas do cluster. As parametrizações do sistema utilizadas para as simulações estão descritas na seção 5.6.2.

\subsection{Geração da Carga de Trabalho}

A geração de uma carga sintética que reproduza o comportamento da carga da Web se torna muito difícil ao se observar a grande variabilidade de suas características. Com a dificuldade encontrada para se definir um modelo de carga que se aplique a todas as situações que possam ser encontradas na Web, em (Teixeira, 2004), no qual este trabalho foi baseado, decidiu-se empregar simulações dirigidas por traces. Essa mesma abordagem será utilizada neste este projeto de mestrado.

Foram pesquisados logs recentes de acesso a servidores web com caractísticas evidentes de sessões de usuários, para que a nova característica de reconhecimento de sessões implantada no modelo SWDS pudesse ser avaliada de maneira mais eficiente. Porém, os logs encontrados se mostravam pequenos, insuficientes para as simulações. Logs maiores, que seriam capazes de suprir as necessidades de carga de trabalho para este projeto, não são fornecidos pelos sites proprietários, alegando a proteção de dados confidenciais de seus usuários.

Assim, o log escolhido para ser usado na geração da carga de trabalho foi o log da copa do mundo de 1998 na França, por ser um log com uma grande quantidade de registros e por ter sido utilizado nas simulações do modelo SWDS desenvolvido por (?). 


\subsubsection{Estudo do Log}

Como discutido no item anterior, em (Arlitt, 2000) encontra-se um estudo sobre a caracterização de Sessões Web o log da Copa do Mundo de 1998, fonecendo resultados relevantes para a geração da carga trabalho utilizada neste trabalho de mestrado.

No estudo de (Arlitt, 2000), vários fatores foram caracterizados, tais como o número de páginas requisitadas por usuários, quantidade de arquivos embutidos em cada página base, quantidade de bytes transferidos e quantidade de tempo ocioso entre sessões e entre requisições.

Para este trabalho, três características se mostraram importantes: o tempo entre as requisições, o número de páginas requisitadas por usuário e a quantidade de arquivos embutidos em cada página. A duas últimas, dizem respeito à quantidade de requisições de uma sessão. Com base nesses resultados, foi definido o valor para a constante Timeout, utilizada para estabelecer um tempo máximo entre requisições de uma sessão, e para verificação da quantidade de requisições obtidas para uma sessão.

\section{Tempo entre requisições de uma sessão}

A informação sobre o tempo entre as requisições de páginas feitas por usuários, colaborou para a geração da carga de trabalho utilizada nos experimentos, a qual será explanada na próxima seção.

Em (Arlitt, 2000) foi constatado que a maior parte dos tempos entre as requisições estiveram entre 0 e 1 segundos, o que indica que a maioria das requisições em uma sessão são geradas automaticamente (para os arquivos embutidos). Outro dado relevante é que, dentre os tempos restantes, a maior parte dos tempos entre requisições de uma sessão, estiveram abaixo de 64 segundos.

Com um estudo mais detalhado sobre o tempo entre requisições de páginas web (Arquivos Bases), foi concluído que o tempo entre requisições de arquivos bases (tempo de pensar do usuário), de modo geral, se apresentava entre 23 e 63 segundos.

\section{Quantidade de requisições de uma sessão}

A caracterização relacionada com a quantidade de requisições de uma sessão se mostrou de grande importância para validação da distribuição modelo, utilizada no método de aceitação de uma nova sessão ao sistema, que será descrita em detalhes na seção 6.5.1. 
Os resultados do estudo desta característica mostra que para a parametrização de 100 segundos considerado como um tempo máximo de uma sessão, 17\% das sessões obtidas eram constituídas por uma única requisição. Dentre essas requisições ainda foram obtidos suas composições:

- $50 \%$ - Arquivos Bases;

- $38 \%$ - Arquivos Embutidos;

- $6 \%$ - Arquivos Únicos;

- 6\% - Arquivos de armazenamento proibido em cache (Requisições dinâmicas e Mensagens de erro).

Entretanto, esses dados se mostram díspares quando confrontados com os dados obtidos por (Arlitt \& Jin, 1999), onde sessões eram de modo geral, constituídas por 88\% de Imagens e $10 \%$ de Arquivos HTML. Com isso, algumas conclusões quanto ao log da Copa foram obtidas. Uma delas é a existência de caching de arquivos, tanto nos clientes, como ao longo da rede, fazendo com que poucas requisições cheguem até os servidores web.

Ainda foi relatado, no log da copa, que arquivos embutidos, como imagens, são geralmente armazenadas em cache e arquivos HTML são configurados para não serem armazenados em cache. Esta característica explica o fato de haver mais requisições de arquivos bases, como visto anteriormente.

Diante dessa situação, a média de requisições de arquivos base por sessão obtida, foi de somente quatro requisições. Esse cenário ainda se deve ao fato de que muitos usuários retornavam ao site somente para verificar os resultados dos jogos. Para os arquivos embutidos, foi obtida uma média de 13 arquivos por arquivo base.

\subsubsection{Processo de Construção da Carga}

Assim como nas simulações realizadas nos experimentos de (Teixeira, 2004), a leitura do $\log$ foi feita de forma seqüencial, considerando-se cada registro lido como uma requisição chegada ao modelo.

Para as simulações iniciais do modelo com a nova característica já adquirida, as sessões foram construídas a partir do log, como no estudo de Martin Arlitt (Arlitt, 2000). Considerou-se, portanto, que um clienteID passaria a representar um endereço IP (Internet Traffic Archive, 1998), o que permitiu identificar várias sessões não simultanemente ativas 
no sistema. Foi parametrizado um tempo máximo permitido entre as requisições de uma mesma sessão. Este tempo foi denominado de Timeout e seu valor configurado foi baseado no tempo chamado Tempo de Pensar do Usuário, como visto no item sobre o estudo do log deste capítulo.

Portanto, a leitura do log foi inicialmente realizada da seguinte maneira: ao chegar uma requisição $r_{i+1}$ do clienteID $C$ ao sistema, $x$ segundos após a requisição $r_{i}$ do clienteID $C$, e $x \leq t$, onde $t$ é o Timeout em segundos, então considera-se que ambas requisições fazem parte da mesma sessão $S_{n}$ para o cliente $C$. Se $x>t$ então a requisição $r_{i}$ passa a ser considerada como a última requisição da sessão $S_{n}$ para o clienteID $C$ e a requisição $r_{i+1}$ se torna a primeira requisição da sessão $S_{n+1}$ para a o clienteID $C$.

Com a variação dos algoritmos de Controle de Admissão de Sessões e de Requisições utilizados nos experimentos, notou-se que a carga de trabalho sofreu modificações entre as simulações, pois quando uma sessão ou requisição era rejeitada ou finalizada, se criava uma nova sessão para o mesmo IP rejeitado. Sendo assim, o número de sessões criadas dependia da quantidade de rejeições ou finalizações de sessões feitas conforme o algoritmo utilizado. Como para cada algoritmo a carga de trabalho se apresentava de maneira diferente, foram obtidos resultados que praticamente não poderiam ser comparados.

Contudo, para as simulações posteriores, passou-se a considerar que um IP identificaria somente uma única sessão e, deste modo, a carga de trabalho seria a mesma para todos os experimentos. Assim, quando uma sessão fosse cancelada ou finalizada, todos os registros deste IP passariam a ser descartados, como se não existissem na carga de trabalho.

\section{Método 1 para leitura do $\log$}

Portanto, o método utilizado para a geração da carga foi realizado da seguinte maneira: ao chegar uma requisição $r_{i+1}$ do clienteID $C$ ao sistema, $x$ segundos após a requisição $r_{i}$ do clienteID $C$, e $x \leq t$, onde $t$ é o Timeout em segundos, então considera-se que $r_{i+1}$ pertence à sessão $S_{n}$ para o cliente $C$. Se $x>t$ então a requisição $r_{i}$ passa a ser considerada como a última requisição da sessão $S_{n}$ para o clienteID $C$ e a requisição $r_{i+1}$ é bloqueada, como se não existisse na carga de trabalho. Todas as requisições posteriores pertencentes a este clienteID $C$, serão bloqueadas, não sendo reconhecidas como carga de trabalho.

Com a grande quantidade de registros descartados, a carga de trabalho se tornou pequena para obterem de resultados precisos. Mesmo assim, foi possível comparar os resultados obtidos em cada experimento com diferentes políticas de controle de admissão de 
sessões e requisições, e com modificações de parâmetros, como o tamanho máximo das filas dos servidores.

\section{Método 2 para leitura do $\log$}

Após a utilização do método anteriomente descrito para a geração da carga de trabalho, uma nova abordagem foi utilizada para a leitura do log. Passou-se a considerar novamente um IP capaz de identificar mais do que uma sessão. Assim, ao chegar uma requisição $r_{i+1}$ do clienteID $C$ ao sistema, $x$ segundos após a requisição $r_{i}$ do clienteID $C$, e $x \leq t$, onde $t$ é o Timeout em segundos, então considera-se que $r_{i+1}$ pertence à sessão $S_{n}$ para o cliente $C$. Se $x>t$ então a requisição $r_{i}$ é desconsiderada e a sessão $S_{n}$ é finalizada. Após isso, enquanto o tempo entre as requisições desta sessão finalizada for menor do que o Timeout, elas são desconsideradas, como se não existissem na carga. Caso ultrapasse esse tempo, uma nova sessão é criada para o mesmo IP da sessão anterior.

\subsection{Classificação de Requisições}

No modelo original SWDS, cada requisição recebia uma classificação, de forma a priorizá-las, pelo módulo Classificador. Aleatoriamente, os rótulos de classes "0"ou "1", menor ou maior prioridade de atendimento respectivamente, eram atribuídas à todas requisições chegadas ao sistema.

Com a nova característica de reconhecimento de sessões, esse modo de classificação se tornou inadequado para as novas simulações do modelo, pois classificar as requisições aleatoriamente para uma mesma sessão não seria mais útil para o estudo. Portanto, o método de classificação de requisições realizado pelo módulo Classificador do modelo SWDS, teve que ser modificado.

A atribuição da mesma classe a todas as requisições de uma sessão foi o método de classificação utilizado. No entanto, para a atribuição de classes às sessões, o mesmo método aleatório foi empregado, portanto, ao chegar uma nova sessão ao sistema, uma função aleatória classifica a sessãoç após isso, cada requisição dessa sessão chegada ao sistema, recebe a mesma classe de sua sessão. 


\subsection{Experimentação do Modelo}

Visando a comparações futuras com os resultados do trabalho de (Teixeira, 2004), foram aqui utilizadas as mesmas parametrizações e a mesma abordagem para a validação do modelo, que passou a ter como nova característica a capacidade de reconhecer sessões web.

\subsubsection{Validação do Modelo}

Para validar o atual modelo SWDS, com sua nova característica, optou-se pela técnica de simulação. Essa escolha se deve ao fato de ser uma abordagem anteriormente utilizada para validação do modelo SWDS no trabalho de (Teixeira, 2004), além de constituir uma abordagem flexível, que permite repetir os experimentos e reproduzir diversos cenários para estudos sem grandes esforços, que seriam inviáveis de se obter através de uma infra-estrutura real.

O simulador escolhido foi o SimPackJ (Fishwick, 1992) composto por métodos voltados à simulação de redes de filas, orientada a eventos discretos. O simulador é distribuído com seu código fonte completo, porém poucas informações são fornecidas sobre sua organização interna, (Fishwick, 2006a).

Inicialmente esse simulador foi escrito em linguagem C, posteriormente em linguagem $\mathrm{C}++$, e mais recentemente em Java. Apesar de experiências anteriores do Grupo de Sistemas Distribuídos e Programação Concorrente com o SimPack desenvolvido em $\mathrm{C}++$, utilizado para a validação do modelo SWDS inclusive, a escolha para este trabalho foi a utilização do simulador desenvolvido em linguagem Java, por se encontrar mais atualizado e por existir mais informações disponíveis sobre suas classes.

Algumas classes importantes do simulador, e utilizadas pelas simulações deste trabalho são:

- Classe VList, (Virtual List) é uma classe abstrata da qual são derivadas todas as outras classes;

- Classe Facility, permite representar os recursos do sistema;

- Classe Future, implementa a lista de eventos futuros (LEF) cujo tipo deve ser definida no início da simulação (Linked, Leftist, Calendar, Heap);

- Classe Linked, implementa uma lista dinâmica duplamente encadeada. Esta lista foi a utilizada neste trabalho, cujo acesso tem complexidade linear. 
Informações mais detalhadas sobre o simulador SimPack/SimPackJ e sua biblioteca Sim, podem ser encontradas em (Fishwick, 2006b).

\subsubsection{Parametrização}

Assim como nos experimentos de validação do modelo SWDS, o foco principal deste trabalho está em avaliar o desempenho do servidor SWDS baseado no atendimento de requisições e, agora, também no atendimento de sessões, sendo capaz de fornecer serviços diferenciados aos seus clientes.

Portanto, detalhes de rede externa e de interconexão entre componentes do servidor não serão modelados, assumindo-se que o meio de comunicação não se apresenta como um gargalo do sistema. Os nós do cluster são modelados separadamente, cada um com sua própria $\mathrm{CPU}$, disco e interface de rede.

Os módulos do servidor SWDS, Classificador, Controle de Admissão, que passsou a ser chamado de Controle de Admissão de Requisições neste trabalho e o novo módulo Controle de Admissão de Sessões, possuem sua própria influência no desempenho global do sistema.

Para o cálculo do tempo de serviço das requisições estáticas, a parametrização para os discos dos servidores é configurada com uma taxa de transferência de 37 MBps e latência de $8,5 \mathrm{~ms}$, tomando-se como referência um disco IBM Deskstar 75GXP (IBM, 2003). Todos servidores do cluster possuem uma interface de rede Fast Ethernet com capacidade real de 80 Mbps. O tempo de serviço das requisições dinâmicas é configurado como 10 ms.

Para todos experimentos feitos neste trabalho, considerou-se que as filas dos servidores do cluster aceitariam uma quantidade máxima de 1024 requisições cada, seguindo o padrão utilizado pelo Apache.

A parametrização para este trabalho foi baseada nas simulações para o modelo SWDS original, já que faz-se necessária a igualdade desses parâmetros para que os resultados possam ser comparados. Alguns trabalhos dessa área também assumem essa parametrização. O resumo da parametrização do modelo pode ser vista na Tabela 5.1.

\subsection{Metodologia de Teste}

A simulação foi a abordagem escolhida para validar a nova caracterísitca de reconhecimento de sessões, bem como os controles desenvolvidos, exibidos nos próximos capítulos. 


\begin{tabular}{|l|r|}
\hline Parâmetro & Valor \\
\hline \hline Capacidade do Classificador & $8000 \mathrm{req} / \mathrm{seg}$ \\
\hline Capacidade do Controle de Admissão de Requisição & $4000 \mathrm{req} / \mathrm{seg}$ \\
\hline Capacidade do Controle de Admissao de Sessão & $4000 \mathrm{req} / \mathrm{seg}$ \\
\hline Taxa de tranferência do disco & $37 \mathrm{MBps}$ \\
\hline Latência do disco & $8,5 \mathrm{~ms}$ \\
\hline Capacidade da interface da rede & $80 \mathrm{Mbps}$ \\
\hline Tempo de serviço das requisições dinâmicas & $10 \mathrm{~ms}$ \\
\hline
\end{tabular}

Tabela 5.1: Parâmetros do modelo SWDS

Para as simulações, o modelo SWDS foi configurado com um cluster formado por quatro servidores web homogêneos, ou seja, onde todos os nós exibem a mesma configuração de hardware e software.

O algorítmo de balanceamento de carga utilizado para alocação das tarefas ou requisições aos nós do cluster, foi o Round Robin (RR), e o Short Queue First (SQF) por serem considerados algoritmos triviais e capazes de atender às necessidades deste trabalho. Não foram utilizados ou criados outros algoritmos de balancemento de carga, já que isto não faz parte do objetivo deste estudo.

A carga de trabalho utilizada é gerada conforme explicado na seção 5.4 e as requisições são classificadas de acordo com a classe de sua sessão, como exposto na seção 5.5. A faixa do $\log$ escolhida para a geração de carga foi entre 3,6 e 4,6 milhões de registros, usando-se todos os servidores do log. Nessa faixa ocorre um súbito aumento da carga de trabalho, situação ideal para se avaliar a eficiência do controle de admissão de sessões desenvolvido.

É importante ressaltar que uma sessão é considerada como finalizada quando todas suas requisições são atendidas. Desse modo, o parâmetro que estabelece que uma sessão terminou, é quando uma requisição pertencente a ela chega ao sistema após um timeout estabelecido, que neste trabalho foi configurado como 100 segundos. Caso uma requisição seja rejeitada pelo sistema, a sessão é considerada como cancelada. Portanto, uma sessão expirada será considerada como finalizada.

\subsection{Considerações Finais}

Neste capítulo apresentaram-se as características de uma sessão e como o reconhecimento dessas características pôde ser adaptado no modelo SWDS.

Além disso, foram explicados o processo de contrução da carga utilizada para as 
simulações realizadas neste trabalho e a maneira de se fazer a classificação das requisições segundo as características das sessões.

O processo de validação do modelo, ou seja, a técnica de simulação foi comentada, assim como o simulador SimPackJ, utilizado para a validação do presente trabalho.

Por fim, foram apresentadas a parametrização do modelo SWDS e a metodologia de teste empregadas nas simulações, voltados à validação do modelo.

No próximo capítulo, será exibido o novo módulo desenvolvido para o controle de admissão de sessões, uma vez que simplesmente atribuir a capacidade de reconhecimento de sessões ao modelo SWDS, não se motiva suficiente. 


\section{Controle de Admissão de Sessões}

\subsection{Considerações Iniciais}

No capítulo anterior, demostrou-se a incorporação da caracterísistica de Reconhecimento de Sessões ao modelo SWDS. Foi exibida a métrica escolhida para a validação do trabalho desenvolvido, as parametrizações e o simulador utilizados. O método para a geração da carga de trabalho também foi explicado.

O modelo de servidor SWDS adquiriu a importante característica de reconhecer sessões HTTP a partir de números IPs encontrados nas informações das requisições de usuários. Entretanto, apenas possuir a capacidade de reconhecimento de sessões, não torna o SWDS um bom fornecedor de serviços diferenciados à sessões de seus clientes. Para que haja um atendimento diferenciado às sessões, garantindo um mínimo de qualidade em seu serviço oferecido, o desenvolvimento de políticas de admissão de sessões torna-se necessário.

Neste capítulo será apresentado o novo módulo de controle de admissão de sessões incluído ao modelo SWDS, bem como sua estrutura e as duas políticas de atendimento à sessões desenvolvidas para este controle. Os mecanismos utilizados para ambas as políticas, serão descritos detadalhadamente.

Por fim, o resultados obtidos por simulações com a utilização das políticas aqui explicadas, são exibidos e comparados. 


\subsection{Controle de Admissão de Sessões - CAS}

Como visto no capítulo anterior, as sessões chegadas ao sitema são reconhecidas pelo módulo de Reconhecimento de Sessões, construído com esse objetivo específico. No entanto, o modelo SWDS, com a nova característica adquirida, deve conservar seu principal objetivo, o fornecimento de serviços diferenciados para seus clientes, atendendo aos níveis de QoS pretendidos. Desse modo, fez-se necessário o desenvolvimento de um novo módulo para o modelo de servidor web que fizesse o controle de atendimento à sessões, denominado, Controle de Admissão de Sessões (CAS).

Por tratar de aspectos realacionados à sessões, esse controle foi desenvolvido junto ao módulo de Reconhecimento de Sessões, relatado no capítulo anterior, como pode ser visto na Figura 6.1.

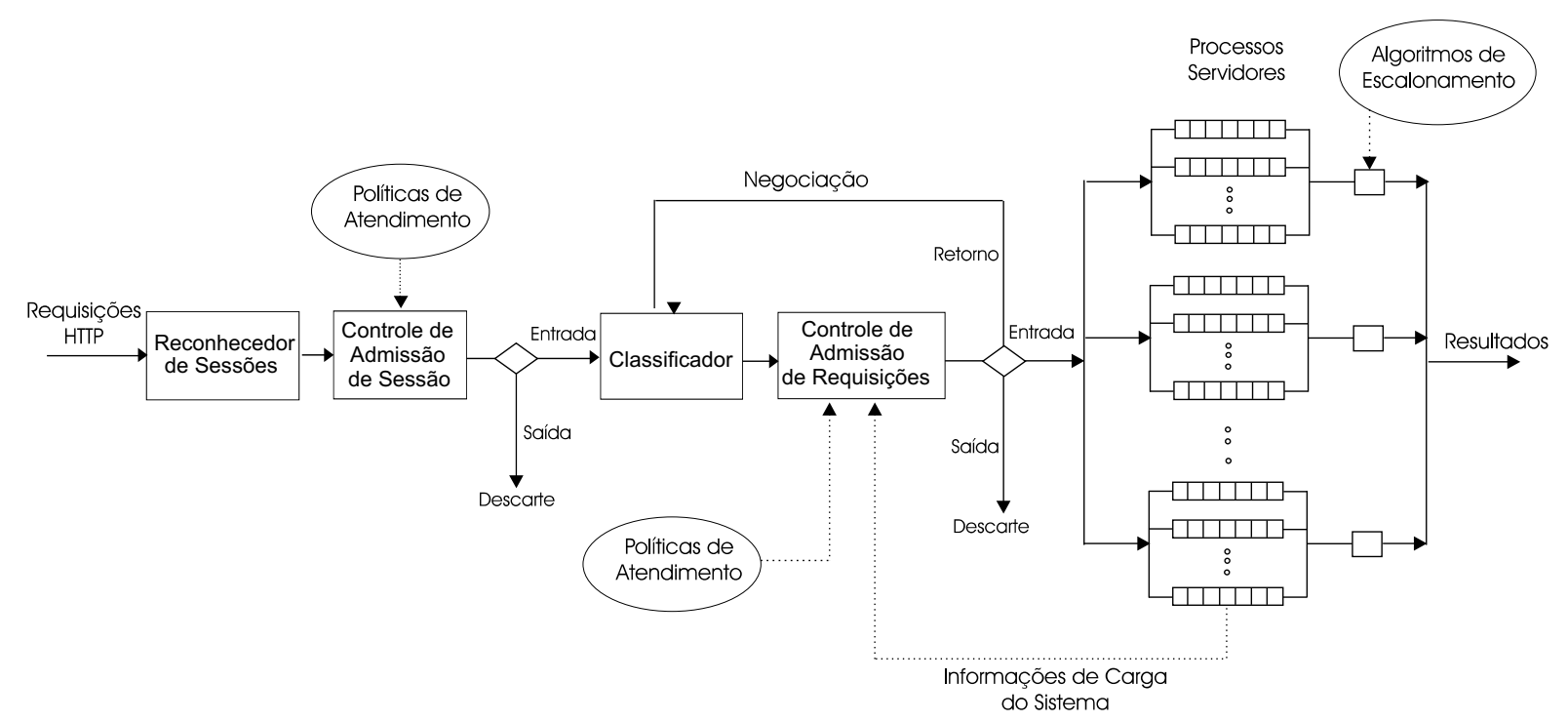

Figura 6.1: Modelo SWDS com o novo controle de admissão de sessões

O controle de admissão de sessões desenvolvido, além de auxiliar a manter a carga do sistema em níveis aceitáveis, tem como maior aspiração, atender completamente todas as sessões que se tornaram ativas no sistema.

Para ajudar a manter a carga do sistema dentro de níveis aceitáveis, esse controle aceita ou rejeita uma nova sessão, conforme o estado em que o servidor se encontra. Caso a carga do sistema, relacionada ao número de sessões ativas, esteja em níveis inaceitáveis, o controle deverá rejeitar uma nova sessão.

Prover garantias de finalização de uma sessão HTTP, tem sido uma caracterísita de grande interesse para os servidores web. A grande quantidade de sites que oferecem 
serviços de comércio eletrônico e de transações comerciais, encontrados na Web, provocam um considerável aumento na carga de trabalho imposta aos servidores. Essa carga ainda traz consigo fortes características de sessões HTTP, onde a finalização dos acessos dos clientes aos servidores se torna especialmente necessário.

Com esse objetivo, foram desenvolvidos métodos para prever se o sistema suportará o atendimento de uma nova sessão por completo, ou seja, o atendimento de todas requisições que a compõem. Esses métodos contribuiram para reduzir a possibilidade de que uma sessão venha a ser cancelada futuramente, já que há maiores possibilidades de que uma requisição pertencente a uma sessão aceita sem a verificação do estado do sistema, seja rejeitada quando este se apresentar sobrecarregado.

\subsubsection{Arquitetura do Módulo de Controle de Admissão de Sessões}

O módulo de admissão de sessões desenvolvido e incorporado ao SWDS (Figura 6.1), tem a função de gerenciar a aceitação de novas sessões ao sistema, evitando que sessões sejam posteriormente canceladas, ao haver sobrecarga ao sistema.

A arquitetura do Controle de Admissão de Sessões é mostrada na Figura 6.2. Destacam-se os seguintes componentes:

- Buffer de Sessões Ativas: é o buffer utilizado para limitar o número de sessões que podem estar ativas no sistema. O limite especificado para este trabalho foi a metade da soma da capacidade das filas do cluster, permitindo ao menos 2 requisições por sessão nas filas do textitcluster caso todas requisições ativas enviem requisições ao sistema;

- Histórico de Sessões: onde é armazenado informações sobre a quantidade de requisições pertencentes às sessões finalizadas no sistema. O número de sessões armazenadas nesse buffer pode ser configurado. Quanto menor o número de sessões, mais freqüente é a atualização do buffer e, conseqüêntemente, mais sucetível a mudanças pontuais da carga o controle se torna, pois, ao se apresentar cheio, as sessões finalizadas mais recentemente tomam o lugar das mais antigas nesse histórico.

- Mecanismo de Controle: onde são utilizadas as políticas de controle de admissão de sessões que serão discutidas posteriormente.

\section{Políticas de Admissão de Sessões}




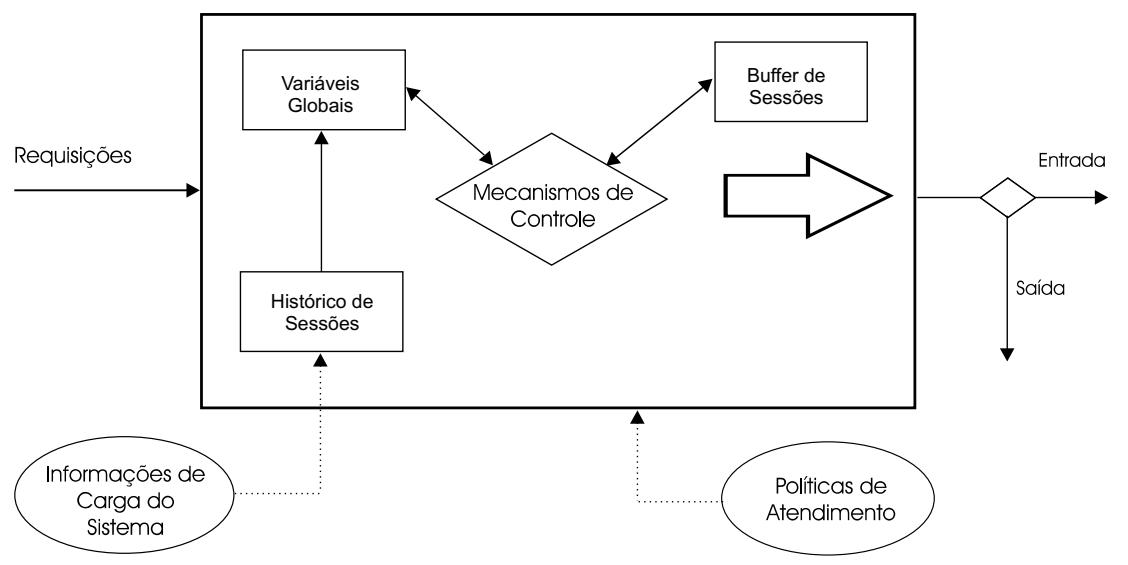

Figura 6.2: Arquitetura do Controle de Admissão de Sessões

Foram desenvolvidas duas políticas de controle de admissão de sessões. Ambas se utilizam informações do buffer de sessões para rejeitar sessões quando há sobrecarga no sistema. No entanto, uma delas utiliza informações do histórico de sessões para construir uma sessão modelo, na qual baseia-se para prever se o sistema será capaz de atendê-la completamente. Com isso o sistema se torna apto a prevenir possíveis cancelamentos de sessões e não somente fazer rejeições de sessões quando o sistema já se apresenta sobrecarregado. As política desenvolvidas foram:

- Hard-Threshold: esta política baseia-se no buffer de sessões ativas, o qual armazena os identificadores de todas as sessões presentes no sistema. Caso a quantidade máxima permitida pelo sistema de sessões ativas (Threshould) venha a ser atingida, o controle rejeita qualquer nova sessão chegada ao sistema.

- Controle Baseado em Sessão Modelo: esta política faz uma previsão para saber se o sistema será capaz de atender a uma sessão completamente, baseando-se em um modelo de sessão, obtido a partir de um histórico de sessões. A sessão será admitida no sistema somente se a previsão indicar que o sistema conseguirá atender todas suas requisições e o buffer de sessões não se encontrar em seu limite, caso contrário, a sessão será rejeitada.

As duas políticas desenvolvidas serão descritas com detalhes ainda neste capítulo, além de serem exibidos os resultados obtidos de simulações realizadas com a utilização das políticas citadas. Porém, anteriormente, será feita uma descrição das métricas utilizadas para este trabalho e da configuração de referência para posteriores comparações de resultados. 


\subsubsection{Seleção das Métricas}

O controle de admissão de sessões depende de informações do sistema para tomar decisões, mais especificamente, baseia-se na análise da carga do sistema para rejeitar ou aceitar uma nova sessão.

Há várias maneiras de se analisar a carga de um sistema. Algumas métricas utilizadas são o tempo de resposta, a utilização do sistema, a taxa de chegada, o nível de ocupação dos buffers e o tamanho das filas.

Além de determinar qual a métrica utilizada, deve-se determinar sua periodicidade. Para melhor retratar o estado do sistema, mais freqüênte deve ser a medição, com o risco de interferências no desempenho global. A abrangência da métrica é outra questão a ser considerada, a qual pode se referir ao comportamento global do sistema ou a alguma informação específica.

Para o novo controle de admissão de sessões do SWDS, foram escolhidas as métricas de nível de ocupação do buffer de sessões ativas e a taxa de chegada de requisições de uma sessão modelo, freqüentemente atualizada com base em um histórico de carga do sistema.

\subsection{Configuração de Referência}

Para verificar a eficiência dos mecanismos de controle de admissão de sessões propostos e suas vantagens no desempenho do servidor SWDS, em relação ao atendimento de sessões, foram realizados experimentos baseados em simulações. A metodologia de teste foi explicada na seção 5.7 e será utilizada em todos experimentos realizados neste trabalho.

Inicialmente, realizou-se um experimento com uma configuração de referência, cujos resultados obtidos permitiram avaliar o desempenho do sistema ao utilizar as políticas de controle desenvolvidas.

Portanto, para esse experimento inicial o módulo de reconhecimento de sessões foi utilizado, porém, o controle de admissão de sessões não foi aplicado. O método de leitura do $\log$ é feito considerando um IP como o representante de uma única sessão. Desse modo, a informação sobre a quantidade máxima de sessões que a carga de trabalho poderá gerar, é obtida.

Com o método 1 de leitura do log, explicado na seção 5.4.2, permitiu se obter como resultado a quantidade máxima de 12053 sessões, visto na Tabela 6.1, ou seja, foram lidos 12053 números de IPs distintos do log. O método de leitura da carga ainda provocou a 
redução de requisições chegadas ao sistema, pois foram lidos 1 milhão de registros do $\log$, mas somente 742933 registros foram consideradas como requisições chegadas ao sistema, como pode ser observado na Tabela 6.2. Essa situação se deve ao fato de que os registros lidos do log, pertencentes às sessões não mais ativas no sistema, passaram a ser bloqueados, como se não existissem na carga de trabalho.

\begin{tabular}{|l|r|}
\hline Informações relacionadas à Sessões & Resultados \\
\hline \hline Chegadas ao sistema & 12053 \\
\hline Rejeições pelo CAS & 0 \\
\hline Admissões & 12053 \\
\hline Cancelamentos pelo CAR & 0 \\
\hline Términos & 10910 \\
\hline Throughput(Sess/Seg) & 5.766384778 \\
\hline
\end{tabular}

Tabela 6.1: Resultados de Referência para Sessões (Sem CAS e CAR)

\begin{tabular}{|l|r|}
\hline Informações relacionadas à Requisições & Resultados \\
\hline \hline Chegadas ao sistema & 742933 \\
\hline Rejeições pelo CAR & 0 \\
\hline Descartes & 0 \\
\hline Admissões & 742933 \\
\hline Retiradas das Filas & 0 \\
\hline Términos & 742819 \\
\hline Throughput(Req/Seg) & 392.610465116279 \\
\hline
\end{tabular}

Tabela 6.2: Resultados de Referência para Requisições (Sem CAS e CAR)

Para se obter a informação da quantidade máxima de requisições da carga de trabalho, nenhum tipo de controle de admissão de requisições foi utilizado. Além disso, não foram impostas restrições ao tamanho das filas dos servidores, para se conhecer o tamanho máximo que as filas podem atingir.

A Tabela 6.3 exibe o maior tamanho que as filas atingiram, para os quatro servidores utilizados nas simulações. Em geral, os servidores atuais são configurados para comportar uma quantidade máxima de 1024 requisições à sua espera, como os servidores Apache. Com os resultados obtidos sobre o tamanho das filas, pôde-se afirmar que o sistema se apresentou sobrecarregado para configurações baseadas em parâmetros reais, como o tamanho máximo de uma fila de um servidor.

O maior tempo de uma sessão também foi obtido, chegando a 1726 segundos. Esse dado será útil para a política de admissão de sessões baseada em sessões, a ser explicada ainda neste capítulo. 


\begin{tabular}{|l|r|}
\hline Servidores & Maior Tamanho da Fila \\
\hline \hline Servidor 1 & 6120 \\
\hline Servidor 2 & 6133 \\
\hline Servidor 3 & 6156 \\
\hline Servidor 4 & 6132 \\
\hline
\end{tabular}

Tabela 6.3: Resultados de Referência de Maior Tamanho das Filas para os Servidores (Sem CAS e CAR)

Baseando-se nesses resultados iniciais, espera-se que a sobrecarga do sistema seja diminuida ao serem utilizados os controles de admissão de sessões, uma vez que novas sessões serão rejeitadas pelas políticas utilizadas nesse controle, para que sessões já ativas no sistema sejam finalizadas. Os resultados obtidos em simulações com o uso dessas políticas, serão demonstrados e comparados nas seções a seguir.

\subsection{Política de Admissão Hard-Threshold}

\subsubsection{Descrição do Mecanísmo}

A política Hard Threshold utilizada no controle de admissão de sessões, foi desenvolvida para controlar a admissão de sessões ao sistema. Essa política baseia-se em uma quantidade máxima de sessões configurada, para tomar decisões sobre aceitar ou rejeitar uma sessão chegada ao sistema.

Para os experimentos realizados, a quantidade máxima permitida de sessões ativas no sistema foi estabelecida como a metade da quantidade máxima de requisições suportadas pelas filas do cluster. Considerou-se que a fila de um servidor comporta 1024 requisições, e que o cluster de servidores é formado por quatro servidores, portanto, permite-se que 2048 sessões estejam ativas no sistema ao mesmo tempo, ou seja, o buffer de sessões comporta esta quantidade de sessões.

O algoritmo utilizado pela política Hard-Threshold, verifica a quantidade de sessões ativas no buffer de sessões, para cada nova sessão chegada ao sistema. Nesse momento o algoritmo toma decisões de aceitar ou rejeitar a sessão. Caso o buffer tenha atingido seu limite, a sessão será rejeitada. Caso contrário, a sessão será aceita no sistema e sua identificação será armazenada no buffer de sessões.

Esse algoritmo é restrito a uma quantidade máxima de sessões no sistema e, portanto, toma a decisão de rejeitar sessões somente se o sistema se apresentar sobrecarregado, não 
fazendo nenhum tipo de estimativa para saber se o sistema será capaz de concluir a sessão após sua aceitação.

A seguir serão mostrados e estudados os resultados obtidos das simulações realizadas com esse algoritmo de controle de sessão.

\subsubsection{Resultados Experimentais}

O principal objetivo dos experimentos realizados é verificar a eficiência das políticas propostas, empregadas no controle de admissão de sessões, observando as vantagens advindas para o desempenho do servidor SWDS em relação ao atendimento de sessões.

A Tabela 6.4 exibe os resultados relativos às sessões, obtidos de simulações onde o Controle de Admissão de Sessões (CAS) foi utilizado e a política Hard Threshold empregada. Verifica-se, portanto, que número de sessões admitidas ao sistema foi reduzido para 11520, sendo que 533 sessões foram rejeitadas pelo controle.

Nesse experimento, nenhum controle de admissão de requisições foi utilizado e também o tamanho das filas não foram restringidos, de modo que se pudesse observar a eficiência do controle de admissão relacionada às sobrecargas do sistema. Mesmo com a utilização dessa política, verifica-se, portanto, que o sistema se apresentou sobrecarregado, já que suas filas atingiram uma quantidade máxima superior a 1024, parâmetro baseado em servidores reais, como pode ser observado na Tabela 6.5.

\begin{tabular}{|l|r|}
\hline Informações relacionadas à Sessões & Resultados \\
\hline \hline Chegadas ao sistema & 12053 \\
\hline Rejeições pelo CAS & 533 \\
\hline * Rejeições por Tamanho do Buffer & 533 \\
\hline * Rejeições por Total de Requisições no Cluster & 0 \\
\hline Admissões & 11520 \\
\hline Cancelamentos pelo CAR & 0 \\
\hline Términos & 10377 \\
\hline Throughput(Sessões/Segundo) & 5.484672304 \\
\hline
\end{tabular}

Tabela 6.4: Resultados para Sessões utilizando a Política Hard-Threshold

Como conseqüência das rejeições de sessões, o número de requisições chegadas ao sistema diminuiu para 717163 requisições (Tabela 6.6), em relação aos resultados obtidos das simulações com a configuração de referência. Este fato é explicado pelo aumento do número de requisições bloqueadas devido às sessões rejeitadas. Quando uma sessão é rejeitada, todas requisições pertencentes a ela serão bloqueadas, como se não existissem na carga de trabalho. 


\begin{tabular}{|l|r|}
\hline Servidores & Maior Tamanho da Fila \\
\hline \hline Servidor 1 & 2602 \\
\hline Servidor 2 & 2628 \\
\hline Servidor 3 & 2635 \\
\hline Servidor 4 & 2608 \\
\hline
\end{tabular}

Tabela 6.5: Maior Tamanho das Filas para os Servidores utilizando a Política Hard-Threshold para o Controles de Admissão de Sessões

\begin{tabular}{|l|r|}
\hline Informações relacionadas à Requisições & Resultados \\
\hline \hline Chegadas ao sistema & 714734 \\
\hline Rejeições pelo CAR & 0 \\
\hline Descartes & 0 \\
\hline Admissões & 714734 \\
\hline Retiradas das Filas & 0 \\
\hline Términos & 714620 \\
\hline Throughput(Requisições/Segundo) & 378.989957716701 \\
\hline
\end{tabular}

Tabela 6.6: Resultados para Requisições utilizando a Política Hard-Threshould

As políticas de admissão de sessões desenvolvidas têm como objetivo controlar a aceitação de sessões no sistema, para qualquer tipo de classe, não fazendo, portanto, qualquer tipo de diferenciação no atendimento das sessões. Essa diferenciação deve ser realizada no controle de admissão de requisições, onde a sessão descartada deverá ser a de menor prioridade, caso ocorra uma sobrecarga no sistema. Por isso, a demonstração de resultados relacionados ao atendimento de classes de prioridade de sessões e requisições, não se faz necessária nesta seção.

\subsection{Política de Admissão Baseada em Sessão Modelo}

\subsubsection{Descrição do Mecanismo}

Nesta seção é apresentada a Política de Admissão de Sessões Baseada em Sessão Modelo. Essa política é empregada no Controle de Admissão de Sessões e fundamenta-se em informações provindas de uma sessão modelo para tomar decisões de rejeição de novas sessões chegadas ao sistema.

O principal objetivo dessa política é o de permitir que uma nova sessão seja aceita no sistema somente se sua aceitação não prejudicar as sessões que já se apresentam ativas e se for previsto que uma vez iniciada a sessão, o sistema tem grandes possibilidades de finalizar a nova sessão, atendendo todas suas requisições com um mínimo de confiabilidade. 
Sucintamente, o mecanismo da política atua do seguinte modo: mediante a requisição de uma nova sessão, o sistema realiza uma previsão da quantidade de requisições que estão sendo esperadas pelas sessões ativas e afere o impacto da aceitação de uma nova sessão na carga do sistema. Caso seja previsto que a admissão da nova sessão trará uma sobrecarga ao sistema, a sessão não será aceita pelo controle. Após essa verificação, a política faz mais um controle caso a sessão tenha sido aceita pela previsão. O controle obtém dados sobre o tamanho do buffer de sessões e caso este esteja em seu limite, a sessão não poderá ser aceita. Essa situação pode acontecer no caso em que a maior parte de sessões ativas estão sendo finalizadas, sendo que a distribuição modelo indicará que espera por uma quantidade pequena de requisições ao sistema, mas por outro lado, a quantidade de sessões ativas é grande.

Para prever a quantidade de requisições esperadas, o controle utiliza informações de uma Distribuição Modelo, ou Sessão Modelo já que ela caracteriza o comportamento de uma sessão, com base em um histórico de sessões finalizadas no sistema.

O controle verifica a aceitação de cada nova sessão chegada ao sistema. Para isso é feita uma estimativa da quantidade de requisições que poderão chegar ao sistema nos próximos $t$ segundos, onde $t$ é o tempo máximo de uma sessão parametrizado no sistema.

Supondo que $R_{t}$ seja o número de requisições previstas para chegarem ao sistema nos próximos $t$ segundos e que a quantidade máxima de requisições suportada pelo sistema seja $C_{\max }$. Seja também $R_{\text {novasessao }}$ a quantidade de requisições previstas para uma nova sessão para os próximos $t$ segundos, TH é o Throughput de requisições, ou seja, a média de requisições atendidas por segundo, e $T_{\text {sessao }}$ é o tempo médio de uma sessão, calculado com base nas sessões ativas do sistema. $R_{\text {fila }}$ é a quantidade de requisições presentes na fila que esperam por atendimento. Então, se a Equação 6.1 for satisfeita, o sistema possui capacidade para atender a nova sessão. Caso contrário, a sessão não será aceita no sistema.

$$
R_{t}+R_{\text {novasessao }}+R_{\text {fila }}-T H * T_{\text {sessao }}<C_{\max }
$$

O Throughput poderia ser multiplicado pelo tempo máximo de uma sessão configurado pelo sistema, pois a estimativa de quantidade de sessões é feita para o tempo de uma sessão, no entanto, devido a variações da carga, optou-se pela obtenção de um tempo médio de sessão, baseado em informações do sistema.

O problema, portanto, consiste em estimar a quantidade de requisições que deverão chegar nos próximos $t$ segundos. Para isso, propõe-se a adoção de uma Distribuição Modelo. 


\section{Distribuição modelo}

A Distribuição Modelo, ou Sessão Modelo, é uma distribuição no tempo, do número de requisições a serem enviadas ao sistema por uma sessão. Para a construção da Distribuição Modelo, é estabelecido um tempo máximo para a duração de uma sessão e um número de intervalos para a discretização do tempo.

Nos experimentos realizados neste trabalho, esses parâmetros foram configurados da seguinte maneira:

Tempo Máximo de uma sessão $=900$ segundos

Número de Intervalos $=100$

A configuração do tempo máximo de uma sessão foi baseada no maior tempo de sessão encontrado no experimento de referência, que foi de 1726 segundos, sendo portanto, configurado como aproximadamente a sua metade. O número de intervalos foi estabelecido aleatoriamente. Com esses valores, a discretização do tempo é calculada, pois ela é obtida pelo resultado da divisão do tempo máximo de uma sessão pelo número de intervalos desse tempo. Portanto se obtém:

Discretização $=900 / 100=9$

O período de duração de uma sessão, 900 segundos, é dividido em 100 intervalos de 9 segundos cada. Para cada requisição de uma sessão, calcula-se em qual intervalo de tempo da sessão ela se encontra. Suponha que uma requisição chegue ao sistema no Tempo $=31$ de uma sessão. O seguinte cálculo nos mostra que a requisição da sessão se encontra no $3^{\circ}$ Intervalo (Timeslot) do tempo discretizado.

\section{$31 / 9=3,4$ aproximadamente}

No sistema, a distribuição modelo é freqüêntemente atualizada. Para isso, foi construído um histórico das últimas $N$ sessões atendidas com sucesso pelo sistema. Quando uma sessão é finalizada, ela é inserida no histórico e a distribuição modelo, atualizada, mantendo o sistema ajustado ao comportamento das sessões. Para as simulações realizadas, o parâmetro $N$ foi configurado com o valor de 5000 sessões. Quanto menor esse valor, mais freqüente é a atualização do buffer e conseqüentemente, mais assídua é a atualização da distribuição modelo, portanto, o controle torna-se propenso a ser sucetível às variações da carga. 
O gráfico da Figura 6.3 e 6.4 exibem o modelo da distribuição obtida no final do experimento onde essa política foi aplicada, para os dois métodos de leitura do log explicados na seção 5.4.2. A partir desses gráficos, pôde-se concluir que a sessão modelo obtida atende ao comportamento visto no estudo sobre a caracterização de sessões no $L o g$ da Copa de 98, feito na seção 1.4.1, onde a maior parte das requisições de uma sessão são enviadas ao servidor logo em seu início.

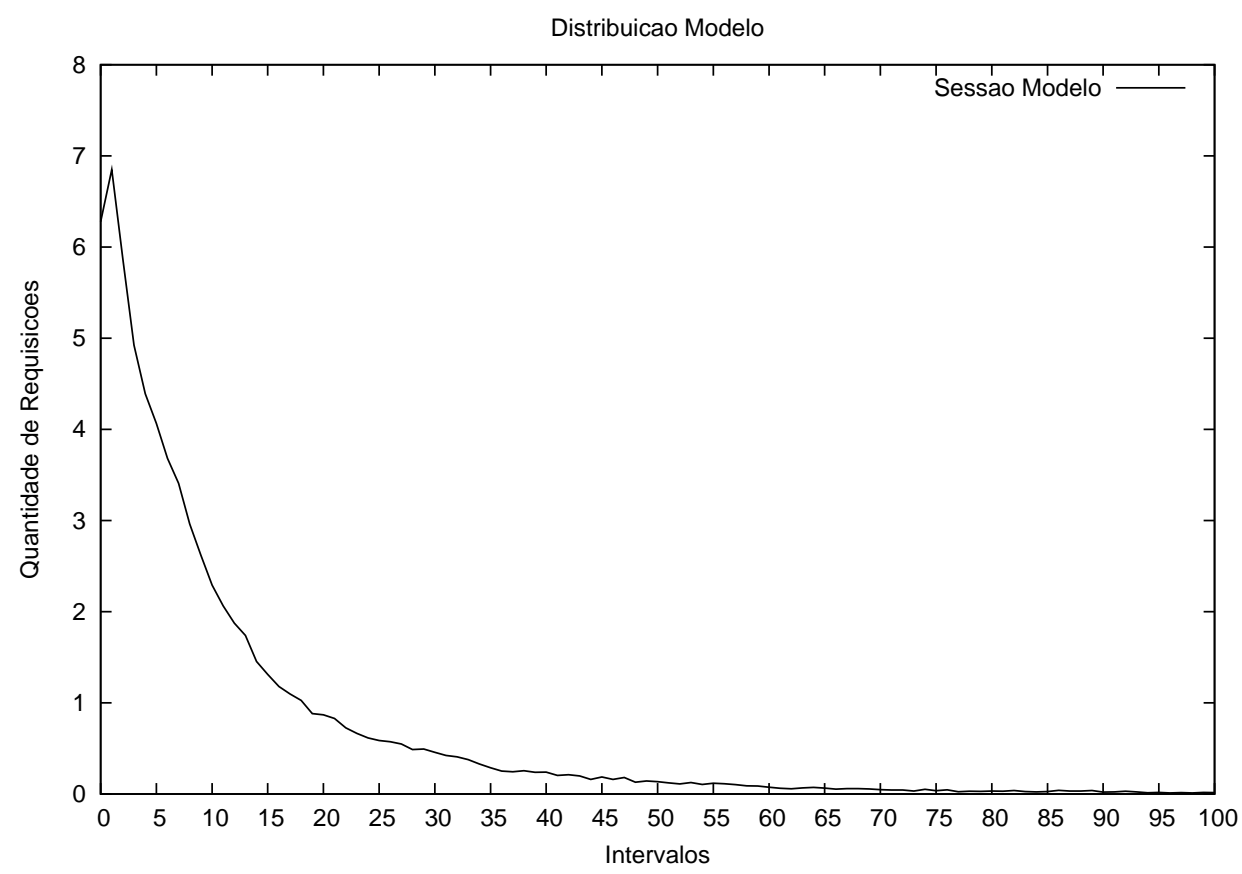

Figura 6.3: Sessão Modelo obtido com o Método 1 de leitura do log

De posse de uma distribuição que estima o comportamento de uma sessão quanto à quantidade de requisições no tempo, é possível prever quantas requisições deverão ser enviadas por uma sessão em um instante qualquer.

Por exemplo, na Figura 6.3, se uma sessão encontra-se no tempo $t=7$, sabe-se que a quantidade de requisições que tende a ser enviada ao servidor é a soma do número de requisições enviadas em $t=7, t=8, \ldots, t=100$. Este resultado fornece o número de requisições estimadas para os próximos $t$ segundos para uma única sessão.

No entanto, é necessário conhecer o número de requisições estimadas para os próximos $t$ segundos para todas as sessões que estão sendo atendidas pelos sistema, $R_{t}$. Para isso, faz-se o cálculo descrito na Equação 6.2.

$$
R_{t}=\sum_{x=i}^{n} r_{i t}
$$




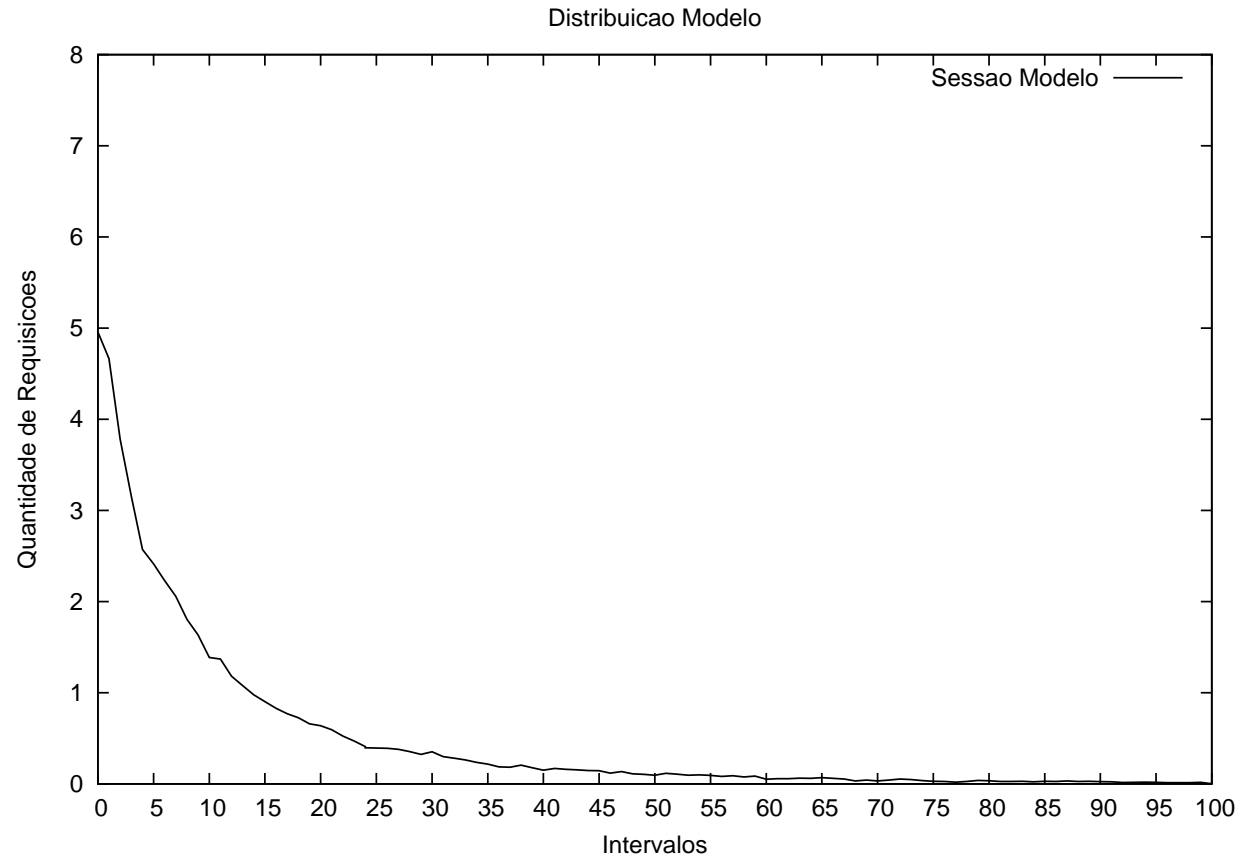

Figura 6.4: Sessão Modelo obtido com o Método 2 de leitura do $\log$

Onde $n$ é o número de sessões ativas no sistema e $R_{t}$ é o numero de requisições estimadas para uma sessão $i$ nos próximos $t$ segundos.

Com $R_{t}$ calculado, a Equação 6.1, para determinar se uma nova sessão será aceita ou não, é facilmente resolvida.

Na próxima seção, serão exibidos os resultados obtidos por simulações onde foram utilizados os algoritmos de CAS explicados anteriormente. Os resultados serão também comparados.

\subsubsection{Resultados Experimentais}

Os resultados obtidos por meio de simulações onde a política de admissão explicada neste capítulo foi empregada, são exibidos nas tabelas a seguir. Na Tabela 6.7 visualiza-se que 533 sessões foram rejeitadas. Como explicado na seção anterior, há duas maneiras dessa política rejeitar uma sessão. O primeiro teste realizado é estimar se o sistema será apto a atender todas requisições da nova sessão para o tempo total de uma sessão configurado (900 segundos), o que nos mostra que um total de 289 sessões foram rejeitadas. Após essa verificação, o controle verifica o tamanho do buffer de sessões e caso este esteja em seu limite, a sessão é rejeitada. Por esse mecanismo, foram rejeitadas 244 sessões.

Com estes resultados pode-se concluir que ocorreram momentos no experimento em 
que as filas dos servidores não se encontrariam cheias para os próximos Tmedio segundos (tempo médio de uma sessão), mas o buffer de sessões se encontrava em seu limite. É provável, portanto, que esta situação ocorreu quando a maioria das sessões ativas, presentes no buffer de sessões, estavam sendo finalizadas, mas haviam tantas sessões ativas no sistema, quanto o limite imposto ao buffer.

\begin{tabular}{|l|r|}
\hline Informações relacionadas à Sessões & Resultados \\
\hline \hline Chegadas ao sistema & 12053 \\
\hline Rejeições pelo CAS & 533 \\
\hline * Rejeições por Tamanho do Buffer & 244 \\
\hline * Rejeições por Total de Requisições no Cluster & 289 \\
\hline Admissões & 11520 \\
\hline Cancelamentos pelo CAR & 0 \\
\hline Términos & 10379 \\
\hline Throughput(Sessões/Segundo) & 5.485729387 \\
\hline
\end{tabular}

Tabela 6.7: Resultados para Sessões utilizando a Política Baseada em Sessão Modelo

\begin{tabular}{|l|r|}
\hline Informações relacionadas à Requisições & Resultados \\
\hline \hline Chegadas ao sistema & 717163 \\
\hline Rejeições pelo CAR & 0 \\
\hline Descartes & 0 \\
\hline Admissões & 717163 \\
\hline Retiradas das Filas & 0 \\
\hline Términos & 717049 \\
\hline Throughput(Requisições/Segundo) & 377.7061311 \\
\hline
\end{tabular}

Tabela 6.8: Resultados para Requisições utilizando a Política Baseada em Sessão Modelo

A quantidade de requisições chegadas ao sistema foi reduzida para 717163, verificado na Tabela 6.8, comparado como o valor de referência (742933 requisições). Como já explicado, este valor obtido se deve à quantidade de requisições bloqueadas de sessões rejeitadas pelo controle.

Nenhum controle de admissão de requisições foi utilizado, bem como os tamanhos das filas não foram restringidos. Com isso, verifica-se que o sistema se apresentou sobrecarregado, já que suas filas atingiram uma quantidade máxima superior a 1024, parâmetro baseado em servidores reais, como pode ser observado na Tabela 6.9. No entanto, as filas se mostraram menores do que para o CAS Hard-Threshold. 


\begin{tabular}{|l|r|}
\hline Servidores & Maior Tamanho da Fila \\
\hline \hline Servidor 1 & 1906 \\
\hline Servidor 2 & 1901 \\
\hline Servidor 3 & 1915 \\
\hline Servidor 4 & 1911 \\
\hline
\end{tabular}

Tabela 6.9: Maior Tamanho das Filas para os Servidores utilizando a Política Baseada em Sesão Modelo para o Controles de Admissão de Sessões

\subsection{Comparação dos resultados para as Políticas do CAS}

Nesta seção, serão comparados os resultados obtidos dos experimentos onde as políticas de admissão de sessões desenvolvidas para o Controle de Admissão de Sessões foram utilizadas.

Pelos resultados obtidos, verifica-se que a quantidade de sessões finalizadas por ambas políticas foi de 11520 sessões. No entanto, encontra-se uma diferença de como estas rejeições foram realizadas. Para a política Hard-Threshold todas as rejeições foram feitas com base em informações do buffer de sessões, onde encontram-se 533 rejeições. Para a política Baseada em Sessão Modelo, foram rejeitadas 244 sessões com base nestas informações do sistema, e 289 por previsões feitas com base nas informações da distribuição modelo.

Apesar de ter a mesma quantidade de sessões rejeitadas, foram obtidos resultados diferentes quanto o atendimento de requisições para as políticas desenvolvidas. Com a política Hard-Threshold o número de requisições chegadas ao sistema foi menor do que para a Baseda em Sessão Modelo. É provável que o mecanismo de previsão de atendimento de uma nova sessão tenha gerado este efeito na carga de trabalho. Com isso, permite-se concluir que para esta política, foram atendidas sessões mais longas, ou seja, com maior número de requisições.

Enfim, de um modo geral, as políticas tiveram um desempenho semelhante, sendo que a Baseada em Sessão Modelo teve uma discreta vantagem sobre a Hard-Threshold devido à quantidade de requisições atendidas.

\subsection{Considerações Finais}

Neste capítulo, apresentou-se a implementação de um dos objetivos principais deste trabalho, o controle de admissão de sessões. Foi mostrada sua arquitetura, bem como sua adequação ao modelo SWDS. 
Foram demonstradas as duas políticas de admissão de sessões desenvolvidas utilizadas para controlar o atendimento das sessões. Ambas políticas se baseiam em informações do sistema, para fazer rejeições de sessões.

A política Hard-Threshold admite sessões no sistema ao verificar que o buffer de sessões não encontra-se em seu limite. A política de admissão de sessões Baseada em Sessão Modelo, permite que uma nova sessão seja atendida pelo sistema caso sua previsão de que o sistema será capaz de atendê-la, feita com base em uma Distribuição Modelo que representa o comportamento de uma sessão, assim o permite.

Por fim, foram apresentados os resultados obtidos de experimentos realizados para cada política abordada e fez-se uma comparação entre eles.

No próximo capítulo, serão descritas as novas políticas de controle de admissão de requisições, as quais foram desenvolvidas para atender as necessidades da nova característica de Reconhecimento de Sessões. 


\section{Controle de Admissão de Requisições}

\subsection{Considerações Iniciais}

No capítulo anterior, apresentou-se o novo módulo de controle de Admissão de Sessões incorporado ao modelo SWDS. Foram estudadas as duas novas políticas desenvolvidas, cuja finalidade é oferecer o atendimento de sessões visando suas finalizações e evitando sobrecargas ao sistema.

A diferenciação de serviços para sessões, se dá por meio da classificação de suas requisições, para isso todas as requisições pertencentes a uma sessão são classificadas com a mesma prioridade, tornando a sessão classificada. Esta atribuição de classes às requisições e, portanto, às sessões, é realizada no módulo Classificador de Requisições do SWDS.

A diferenciação no atendimento de requisições, no entanto, é feita em parte, no módulo de Controle de Admissão de Requisições através de políticas de atendimento às requisições. Outra função, e a principal deste módulo, é manter o sistema livre de sobrecargas e, para isso, requisições são rejeitadas utilizando-se esse controle.

Este capítulo estuda o Controle de Admissão de Requisições e descreve todo o processo realizado para a rejeição de requisições, que passou a se preocupar não somente com requisições de forma isolada, mas também, com o atendimento de sessões, quando uma requisição é rejeitada pelo sistema. 


\subsection{Mecanismo de Controle}

O Controle de Admissão de Requisições tem como principal função gerenciar a aceitação de novas requisições pelo servidor, em vista de impedir que o mesmo atinja a sobrecarga.

A arquitetura deste módulo foi explicada com detalhes na seção 4.3 desta dissertação, bem como as políticas desenvolvidas em (Teixeira, 2004) para realizar o controle de admissão de novas requisições chegadas ao sistema.

Os mecanismos de admissão de requisições desenvolvidos no modelo original, foram criados para o atendimento de requisições sem a visão ao atendimento à sessões. Com isso, passa a ser necessário que os algoritmos anteriormente criados sejam alterados para se adequarem a nova característica, ou novos mecanismos de atendimento sejam desenvolvidos, para suprir as necessidades impostas pela nova característica de reconhecimento de sessões.

Este trabalho utilizou como fundamento um mecanismo criado por (Teixeira, 2004) para o atendimento de requisições, o Mecanismo de Admissão segundo o Tamanho de Filas. Porém, novas característica tiveram que ser adicionadas a esse mecanismo para se adequar ao atendimento de sessões.

Sua estrutura não sofreu alterações para suprir as necessidades da nova característica incorporado ao modelo. Apenas novas informações do sistema, relacionadas às sessões, foram coletadas para isso. A partir dessas informações, o controle passou a dar importância ao atendimento de requisições visando também o atendimento de sessões.

\subsubsection{Políticas de Admissão de Requisições}

Para atender as necessidade da nova característica de reconhecimento de sessões, foram criadas novas políticas que visam a admissão de requisições, adaptadas ao atendimento de sessões.

As duas políticas desenvolvidas apoiam-se na informação sobre o tamanho das filas do cluster. Caso as filas se apresentem em seu limite de capacidade, requisições devem ser rejeitadas e, como consequência, a sessão a qual elas pertencem deve ser cancelada, controlando com isso, a sobrecarga ao sistema.

A diferença entre as políticas está na escolha de qual requisição será retirada do sistema quando este se apresentar sobrecarregado. As políticas de admissão desenvolvidas são: 
- Admissão segundo o Tamanho das Filas sem Negociação: A requisição a ser retirada do sistema é a que foi rejeitada.

- Admissão segundo o Tamanho das Filas com Negociação: A requisição a ser retirada do sistema é escolhida por meio de Negociação.

O atendimento diferenciado de requisições é feito, portanto, por uma política de negociação aplicada ao controle, que prevalece o atendimento de requisições de maior prioridade, conseqüentemente, de sessões de maior prioridade, já que todas as requisições de uma sessão possuem a mesma classificação. Desse modo, a diferenciação de serviços oferecida pelo modelo SWDS inclui em seus requisitos de QoS oferecidos, o atendimento diferenciado de sessões.

Ambas políticas de admissão serão explicadas com detalhes neste capítulo. Em adição, os resultados obtidos de simulações com a utilização dessas políticas serão exibidos e comparados.

\subsubsection{Seleção de Métricas}

Assim como o Controle de Admissão de Sessões, este controle apoia-se em informações da carga do sistema para decidir se uma requisição poderá ser atendida pelo servidor.

Para o controle de Admissão de Requisições do modelo SWDS original, utilizaram-se métricas como, o tamanho das filas dos servidores do cluster, o tempo de resposta da classe de maior prioridade e uma média exponencial ponderada da utilização do sistema.

Entretanto, para esse controle, a única métrica utilizada será a de tamanho de filas, pois, deve-se lembrar que o foco deste projeto não é apenas o desenvolvimento de mecanismos de controle de admissão mas, de modo geral, é permitir que a característica de reconhecimento de sessões possa ser implantado o modelo, sendo necessário para isso alguns ajustes no SWDS. Portanto, novos algoritmos de controle de admissão de requisições com base em sessões e com varios tipos de métricas, poderão ser desenvolvidos em trabalhos futuros.

\subsection{Admissão segundo o Tamanho das Filas Sem Negociação}

\subsubsection{Descrição do Mecanismo}

Esta política baseia-se no mecanismo de admissão de requisições segundo tamanho de filas, desenvolvida em (Teixeira, 2004), em seu modelo SWDS. Porém, a rejeição de uma 
requisição passa a implicar no cancelamento de sua sessão.

A política estabelece um tamanho máximo para as filas dos servidores do cluster. Caso uma requisição chegue ao sistema e encontre todas as filas com este limiar alcançado, ela será sumariamente recusada, independente de sua classe e de qualquer tipo de informações pertinentes a sua sessão.

Essa abordagem é semelhante à encontrada no servidor web Apache, com a qual novas requisições HTTP são rejeitadas caso o tamanho de sua fila ultrapasse 1024 clientes. Em nível de rede esta abordagem é também encontrada, onde pacotes mais novos são rejeitados por dipositivos roteadores.

Com essa política, quando há uma sobrecarga no sistema, uma nova requisição chegada ao sistema é rejeitada pelo controle de admissão de requisições e sua respectiva sessão deve ser descartada. Portanto, a sessão descartada será sempre a da requisição que chegou ao sistema, para a qual seu atendimento foi negado.

O descarte de uma sessão implica, de forma geral, em inutilizar todo o processamento já realizado a esta sessão. O pior caso, portanto, é quando uma sessão está prestes a ser finalizada e sua última requisição é rejeitada. Caso houver ainda alguma requisição dessa sessão presente nas filas do cluster, ela deve ser, então, excluída, pois seu processamento seria inútil após o cancelamento de sua sessão.

\subsubsection{Resultados Experimentais}

Realizou-se um experimento, no qual foi utilizado como controle de admissão de requisição o algoritmo baseado no tamanho das filas do Cluster, sem nenhum tipo de negociação para a escolha de qual requisição deveria ser descartada. Não foi utilizado também nenhum tipo de controle de admissão de sessões, para se obter resultados especificamente relacionados ao atendimento a requisições. A leitura do log foi realizada conforme o método 1, descrito na seção 5.4.2.

A Tabela 7.1 exibe os resultados relacionados às sessões com o uso dessa política. Observa-se, portanto, que 359 sessões foram canceladas devido à rejeição de requisições pelo controle de admissão de requisições.

Os resultados relacionados às requisições são visualizados na Tabela 7.2. As rejeições de requisições feitas pelo controle de admissão é observado pelo item Rejeições pelo $C A R$. A rejeição de uma requisição, provoca o cancelamento de sua sessão e com isso todas as requisições pertencentes a essa sessão cancelada que estão no sistema são descartadas (Descartes) 


\begin{tabular}{|l|r|}
\hline Informações relacionadas à Sessões & Resultados \\
\hline \hline Chegadas ao sistema & 12053 \\
\hline Rejeições pelo CAS & 0 \\
\hline Admissões & 12053 \\
\hline Cancelamentos pelo CAR & 359 \\
\hline Términos & 10554 \\
\hline Throughput(Sess/Seg) & 5.578224101 \\
\hline
\end{tabular}

Tabela 7.1: Resultados sobre Sessões para Política de Admissão Segundo o Tamanho das Filas Sem Negociação

e as requisições que estão nas filas dos servidores são excluidas (Retiradas das Filas). Com as requisições rejeitadas e suas respectivas sessões canceladas, o sistema se mostrou livre de sobrecarga durante toda a simulação.

Na seção 7.6, esses resultados serão comparados com os obtidos em simulações onde se utilizou o outro algoritmo de controle de admissão desenvolvido, o qual utiliza o mecanismo de Negociação.

\begin{tabular}{|l|r|}
\hline Informações relacionadas à Requisições & Resultados \\
\hline \hline Chegadas ao sistema & 717798 \\
\hline Rejeições pelo CAR & 359 \\
\hline Descartes & 30 \\
\hline Admissões & 717409 \\
\hline Retiradas das Filas & 3660 \\
\hline Términos & 713628 \\
\hline Throughput(Req/Seg) & 377.181818181818 \\
\hline
\end{tabular}

Tabela 7.2: Resultados para Requisições para Política de Admissão Segundo o Tamanho das Filas Sem Negociação

\subsection{Admissão segundo o Tamanho de Fila com Negociação}

\subsubsection{Descrição do Mecanismo}

O segundo controle de admissão desenvolvido utiliza políticas de negociações para escolher a sessão que deverá ser cancelada quando uma requisição for rejeitada. Ao encontrar uma sessão ativa no sistema que satisfaça aos requisitos de descarte da política, esta será cancelada no lugar da sessão da requisição rejeitada. A requisição é então atendida pelo sistema e todas as requisições da sessão cancelada que estiverem nas filas dos servidores, serão descartadas. 
Portanto, a sessão descartada será uma sessão escolhida pelo sistema conforme a política de negociação utilizada. Foram desenvolvidas três políticas de negociação de sessões, baseadas em quantidade de requisições por sessão, por sessão mais recente e por prioridade de sessões. Os algoritmos desenvolvidos serão explicados a seguir e, logo após, os resultados obtidos nas simulações para os três algoritmos serão mostrados e comparados.

\subsubsection{Políticas de Negociação para Descarte de Sessões}

\section{Negociação por sessão mais recente}

Esta política de negociação de sessão, tem como principal objetivo a preservação de sessões ativas que estão há mais tempo no sistema, as quais possuem maior probabilidade de finalização.

Quando uma requisição chega ao sistema e este se encontra sobrecarregado, este mecanismo busca por uma sessão no Buffer de Sessões Ativas que esteja há menos tempo ativa no sistema, para ser cancelada. Para não desperdiçar serviços dos recursos do sistema, todas as requisições pertencentes a essa sessão que se encontram nas filas dos servidores, ou em qualquer outro recurso, são excluídas.

\section{Negociação por sessão mais recente e de menor duração}

Esta política além de preservar as sessões ativas mais antigas no sistema, como a apresentada no item anterior, ainda se preocupa em preservar as sessões que estiveram ativas por mais tempo no sistema, já que teoricamente, estas sessões têm maiores probabilidades de finalização. O mecanismo busca a sessão mais recente no sistema dentre as sessões de menor tempo de duração.

A duração de uma sessão é considerada como o tempo entre a primeira e a última requisição emitida por uma sessão. Portanto, uma sessão mais antiga no sistema que tenha seu período de duração menor do que uma sessão mais recente no sistema, deve ser cancelada por esta política.

\section{Negociação por sessão mais recente, menor tempo de duração e de classe baixa}

Esta política de negociação preza por atender sessões de maior prioridade e ao mesmo tempo por fazer com que sessões que se encontram a mais tempo ativa no sistema continuam sendo atendidas. 
Neste caso, ao utilizar esta política, o modelo irá priorizar o cancelamento de sessões cuja classe será de menor prioridade. Para isso, as classes atribuídas às sessões pelo Classificador do SWDS, serão verificadas. Neste trabalho, as sessões foram classificadas em classes 0 e 1 , menor e maior prioridade, respectivamente.

\section{Negociação por sessão mais recente e de menor tamanho}

Com a informação da quantidade de requisições armazenada de cada sessão ativa no sistema, esta política toma decisões de qual sessão deve ser cancelada, caso uma requisição seja rejeitada quando o sistema se encontra sobrecarregado.

Esta política além de preservar as sessões ativas mais antigas no sistema, ainda se preocupa em preservar as sessões que tiveram mais requisições processadas pelos servidores do cluster, caso ocorra uma sobrecarga no sistema. Deste modo, com a utilização desta política, evita-se desperdiçar todo o processamento já realizado para as requisições das sessões que serão canceladas.

\subsubsection{Comparação de resultados experimentais entre políticas de negociação}

A seguir, serão comparados os resultados obtidos por simulações que utilizaram os controles explicados até o momento. As tabelas a seguir mostram os resultados para o algoritmo de controle de admissão por tamanho de filas e baseado em sessões, utilizando cada política de negociação explicada nos itens anteriores.

Pela Tabela 7.3, pode-se observar que o CAR por tamanho de fila e baseado em sessões, rejeitou mais requisições chegadas ao sistema (Rejeições pelo CAR) ao ser empregada a política de negociação de sessões mais novas, dentre as políticas de negociação utilizadas.

\begin{tabular}{|l|r|r|r|r|}
\hline Info. sobre Requisições & Mais Nova & Menor Duração & Classe 1 & Menor Tam. \\
\hline \hline Chegadas ao sistema & 716034 & 716357 & 716727 & 716695 \\
\hline Rejeições pelo CAR & 19 & 1 & 1 & 2 \\
\hline Descartes & 10 & 20 & 12 & 16 \\
\hline Admissões & 716009 & 716350 & 716721 & 716676 \\
\hline Retiradas das Filas & 1304 & 1068 & 1435 & 1170 \\
\hline Términos & 714587 & 715154 & 715165 & 715393 \\
\hline Chegadas - Términos & 1329 & 1071 & 1441 & 1302 \\
\hline Throughput(Req/Seg) & 377.68868922 & 377.98837209 & 377.99418605 & 378.1146934 \\
\hline
\end{tabular}

Tabela 7.3: Comparação para Requisições entre Políticas de Negociação 
Porém, a real quantidade de rejeições é obtida somando-se a esta quantia, o número de requisições retiradas das filas do cluster, quando uma sessão ativa no sistema é escolhida para descarte em lugar da sessão pertencente à requisição rejeitada. Com isso, a quantidade de requisições atendidas (Términos) para o CAR com negociação por sessão mais nova, é inferior aos outros algoritmos de negociações, pois os outros algoritmos procuram cancelar sessões de menor duração, que provavelmente haviam enviado ao sistema menos requisições antes de serem canceladas.

A Tabela 7.4 de Resultados sobre Sessões mostra que nenhuma sessão foi rejeitada, pois não foram utilizados controles de admissão de sessões, porém, para as quatro políticas de negociação, sessões foram canceladas, pois, uma requisição ao ser rejeitada pelo controle de admissão de requisições, sua sessão é cancelada e todas as requisições pertencentes a sessão cancelada que estiverem na fila do cluster são excluídas.

\begin{tabular}{|l|r|r|r|r|}
\hline Informações sobre Sessões & Mais Nova & Menor Duração & Classe 1 & Menor Tamanho \\
\hline \hline Chegadas ao sistema & 12053 & 12053 & 12053 & 12053 \\
\hline Rejeições pelo CAS & 0 & 0 & 0 & 0 \\
\hline Admissões & 12053 & 12053 & 12053 & 12053 \\
\hline Cancelamentos pelo CAR & 604 & 627 & 538 & 606 \\
\hline Términos & 10308 & 10285 & 10375 & 10306 \\
\hline Throughput(Sess/Seg) & 5.44820296 & 5.436046512 & 5.483615222 & 5.447145877 \\
\hline
\end{tabular}

Tabela 7.4: Comparação para Sessões entre Políticas de Negociação

Um dado relevante encontrado na Tabela 7.4, é que para a negociação de descarte de sessões de menor duração foram atendidas menos sessões do que para os outros algoritmos de negociação. Esta situação pode ter ocorrido, devido à maior quantidade de cancelamentos de sessões, já que ao cancelar sessões de menor duração, mais sessões tiveram que ser canceladas para manter o sistema livre de sobrecargas.

Outro resultado relevante é que com o algoritmo de negociação de sessão mais nova, de menor duração e de classe baixa, a quantidade de requisições terminadas foi ainda maior do que o de descarte de sessão mais nova e de menor duração. A classificação de sessões foi aleatória, portanto, coincidentemente as sessões de classe 0, escolhidas para serem canceladas, haviam enviado ao sistema menos requisições do que as de classe 1. Entretanto, todas as sessões de classe 1 (maior prioridade) chegadas ao sistema, foram atendidas, com a utilização do algoritmo de negociação que procura descartar sessões de classe baixa, ou seja, atendendo ao seu principal objetivo, o que pode ser visto na Tabela 7.5 de classes de sessões.

Em relação às filas dos servidores, para todos os experimentos onde as políticas de negociação foram utilizadas, as filas mantiveram-se abaixo do limite configurado (1024 


\begin{tabular}{|l|r|r|}
\hline Informações relacionadas à Sessões & Classe 0 & Classe 1 \\
\hline \hline Admissões $(0 / 1)$ & 6112 & 5941 \\
\hline Canceladas $(0 / 1)$ & 538 & 0 \\
\hline Términos $(0 / 1)$ & 4434 & 5941 \\
\hline Throughput(Requisições/Segundo) $(0 / 1)$ & 2.343551797 & 3.140063425 \\
\hline
\end{tabular}

Tabela 7.5: Resultados para Classes de Sessões para CAR com Negociação

requisições).

\subsection{Comparação de resultados entre algoritmos de CAR}

Os resultados exibidos nas tabelas anteriores permitem concluir que apesar de o algoritmo de CAR por tamanho de fila sem negociação ter permitido o atendimento de maior quantidade de sessões em relação ao algoritmo de CAR baseado em sessões, para todas políticas de negociações, a quantidade de requisições atendidas foi menor.

Porém, em relação ao seu principal objetivo, gerenciar a admissão de requisições no sistema, o algoritmo de CAR por tamanho de fila sem negociação se mostrou menos eficiente, já que acabou rejeitando mais requisições do que para o outro controle desenvolvido, o qual utiliza políticas de negociação. Com isso, deduz-se que a maior parte das sessões atendidas para o CAR por tamanho de fila sem negociação, eram as que tinham poucas requisições. Portanto, sessões maiores, ou seja, com maior quantidade de requisições, puderam ser canceladas e todo o processamento de requisições anteriormente atendidas foi desperdiçado. Assim, a quantidade de requisições que são retiradas das filas do cluster para o algoritmo de CAR por tamanho de fila se mostrou maior do que o dobro para o algoritmo por tamanho de fila baseado em sessões com negociação.

Em um cenário de um site de comércio eletrônico, por exemplo, se considerarmos como se a última requisição de uma sessão enviada ao servidor fosse a confirmação de uma compra por um cliente, a política de CAR sem negociação poderia provocar a perda de todo procedimento de compra, caso esta requisição não pudesse ser processada, já que a sessão cancelada seria a da requisição rejeitada. Enquanto isso, uma outra sessão em que o cliente estivesse somente passeando pelo site, ou seja, de menor prioridade de atendimento, continuaria sendo atendida. Logicamente, o atendimento da sessão no primeiro caso se mostra de maior importância. Portanto, ao avaliar este cenário, permite-se afirmar que a política de CAR por Tamanho de Fila sem negociação se mostra inflexível quanto à escolha de descarte de requisições, sem existir qualquer opção de escolha de qual sessão deve ser 
cancelada caso uma requisição seja rejeitada pelo sistema, situação esta que poderá ser contornada com as políticas de negociação desenvolvidas.

Enfim, com os resultados obtidos por meio de simulações, exibidos nas tabelas anteriores, pode-se concluir que os dois algoritmos de CAR desenvolvidos, atenderam seus objetivos. Porém, o CAR por tamanho de fila com negociação passa a ser melhor empregado quando se tem uma maior preocupação de se evitar cancelar uma sessão mais antiga no sistema, que possui maior probabilidade de ser finalizada.

\subsection{Controle de Admissão de Sessão e Controle de Admissão de Re- quisições}

Nesta seção serão exibidos os resultados obtidos de simulações onde cada CAS foi utilizado junto a uma política de CAR desenvolvida. A parametrização utilizada foi a descrita na seção 5.6.2. Foram utilizados os dois métodos de leitura do $\log$ descritos da seção 5.4.2. Serão feitas comparações entre os resultados obtidos, das quais algumas conclusões poderão ser tiradas.

\subsubsection{Comparação dos resultados para os CAS com CAR Tamanho de Fila Sem Negociação}

As Tabelas 7.6 e 7.7 mostram os resultados relacionados às sessões com os métodos de leitura do $\log 1$ e 2 respectivamente, obtidos de simulações para cada controle de admissão de sessão simulado em conjunto com o controle de admissão de requisições por tamanho de fila. Percebe-se, portanto, que a quantidade de sessões atendidas foi quase a mesma para ambos CAS, porém para o CAS Baseado em Sessão Modelo, rejeitou-se mais sessões que o outro controle. Com isso, menos sessões foram canceladas pelo sistema, já que sua previsão assim permitiu e, portanto, mais requisições foram atendidas como visto nas Tabelas 7.8 e 7.9 .

De posse desses resultados, permite-se concluir que o CAS baseado em Sessão Modelo teve um ligeiro melhor desempenho, devido ao atendimento de maior quantidade de requisições pelo sistema, com quase a mesma quantidade de sessões completadas. Isso se deve ao fato de que o CAR permitiu que sessões mais longas pudessem ser atendidas com um maior número de rejeições de novas sessões. 
Controle de Admissão de Requisições

\begin{tabular}{|l|r|r|}
\hline Informações sobre Sessões & CAS Hard-Threshold & CAS Sessão Modelo \\
\hline \hline Chegadas ao sistema & 12053 & 12053 \\
\hline Rejeições pelo CAS & 259 & 364 \\
\hline Admissões & 11794 & 11689 \\
\hline Cancelamentos pelo CAR & 274 & 169 \\
\hline Términos & 10380 & 10379 \\
\hline Throughput(Sess/Seg) & 5.486257928 & 5.485729387 \\
\hline
\end{tabular}

Tabela 7.6: Resultados sobre Sessões para CAS em conjunto com CAR por Tamanho de Fila sem Negociação utilizando o método 1 de leitura do log

\begin{tabular}{|l|r|r|}
\hline Informações sobre Sessões & CAS Hard-Threshold & CAS Sessão Modelo \\
\hline \hline Chegadas ao sistema & 21277 & 21277 \\
\hline Rejeições pelo CAS & 3045 & 3212 \\
\hline Admissões & 18227 & 18064 \\
\hline Cancelamentos pelo CAR & 295 & 188 \\
\hline Términos & 15891 & 15835 \\
\hline Throughput(Sess/Seg) & 8.39904862579281 & 8.36945031712473 \\
\hline
\end{tabular}

Tabela 7.7: Resultados sobre Sessões para CAS em conjunto com CAR por Tamanho de Fila sem Negociação utilizando o método 2 de leitura do $l o g$

\begin{tabular}{|l|r|r|}
\hline Informações sobre Requisições & CAS Hard-Threshold & CAS Sessão Modelo \\
\hline \hline Chegadas ao sistema & 708510 & 715483 \\
\hline Rejeições pelo CAR & 274 & 169 \\
\hline Descartes & 28 & 27 \\
\hline Admissões & 708211 & 715295 \\
\hline Retiradas das Filas & 2614 & 1730 \\
\hline Términos & 705597 & 713565 \\
\hline Throughput(Req/Seg) & 372.8752643 & 377.0840381 \\
\hline
\end{tabular}

Tabela 7.8: Resultados sobre Requisições para CAS em conjunto com CAR por Tamanho de Fila sem Negociação utilizando o método 1 de leitura do $\log$

\begin{tabular}{|l|r|r|}
\hline Informações sobre Requisições & CAS Hard-Threshold & CAS Sessão Modelo \\
\hline \hline Chegadas ao sistema & 839021 & 844703 \\
\hline Rejeições pelo CAR & 295 & 188 \\
\hline Descartes & 25 & 25 \\
\hline Admissões & 838707 & 844494 \\
\hline Retiradas das Filas & 2438 & 1859 \\
\hline Términos & 836125 & 842492 \\
\hline Throughput(Req/Seg) & 441.926532769556 & 445.291754756871 \\
\hline
\end{tabular}

Tabela 7.9: Resultados sobre Requisições para CAS em conjunto com CAR por Tamanho de Fila sem Negociação utilizando o método 2 de leitura do $\log$ 


\subsubsection{Comparação dos resultados para os CAS com CAR Tamanho de Fila e Negociação de Sessão Mais Recente}

Os resultados obtidos para cada CAS simulados com o CAR por Tamanho de Fila baseado em sessões e com a política de negociação de sessão mais recente, podem ser visualizados nas Tabelas 7.10 e 7.11 sobre sessões e nas Tabelas 7.12 e 7.13 sobre requisições. Novamente pode-se perceber que o CAS baseado em sessões obteve um melhor desempenho quanto ao atendimento de sessões e requisições. Este fato ocorre devido ao cancelamento de menor quantidade de sessões pelo CAR, já que o CAS, baseado em um modelo de sessão, rejeita novas sessões ao prever que o sistema não seria capaz de atender todas suas possíveis requisições.

\begin{tabular}{|l|r|r|}
\hline Informações sobre Sessões & CAS Hard-Threshold & CAS Sessão Modelo \\
\hline \hline Chegadas ao sistema & 12053 & 12053 \\
\hline Rejeições pelo CAS & 0 & 289 \\
\hline Admissões & 12053 & 11764 \\
\hline Cancelamentos pelo CAR & 604 & 290 \\
\hline Términos & 10308 & 10333 \\
\hline Throughput(Sess/Seg) & 5.44820296 & 5.46141649 \\
\hline
\end{tabular}

Tabela 7.10: Resultados sobre Sessões para CAS em conjunto com CAR por Tamanho de Fila com Negociação de Sessão Mais Recente utilizando o método 1 de leitura do log

\begin{tabular}{|l|r|r|}
\hline Informações sobre Sessões & CAS Hard-Threshold & CAS Sessão Modelo \\
\hline \hline Chegadas ao sistema & 21277 & 21277 \\
\hline Rejeições pelo CAS & 2742 & 3146 \\
\hline Admissões & 18535 & 18129 \\
\hline Cancelamentos pelo CAR & 722 & 296 \\
\hline Términos & 15772 & 15792 \\
\hline Throughput(Sess/Seg) & 8.33615221987315 & 8.34672304439746 \\
\hline
\end{tabular}

Tabela 7.11: Resultados sobre Sessões para CAS em conjunto com CAR por Tamanho de Fila com Negociação de Sessão Mais Recente utilizando o método 2 de leitura do log 


\begin{tabular}{|l|r|r|}
\hline Informações sobre Requisições & CAS Hard-Threshold & CAS Sessão Modelo \\
\hline \hline Chegadas ao sistema & 716034 & 715468 \\
\hline Rejeições pelo CAR & 19 & 8 \\
\hline Descartes & 10 & 4 \\
\hline Admissões & 716009 & 715454 \\
\hline Retiradas das Filas & 1304 & 500 \\
\hline Términos & 714705 & 714954 \\
\hline Throughput(Req/Seg) & 377.6886892 & 377.8234672 \\
\hline
\end{tabular}

Tabela 7.12: Resultados sobre Requisições para CAS em conjunto com CAR por Tamanho de Fila com Negociação de Sessão Mais Recente utilizando o método 1 de leitura do log

\begin{tabular}{|l|r|r|}
\hline Informações sobre Requisições & CAS Hard-Threshold & CAS Sessão Modelo \\
\hline \hline Chegadas ao sistema & 846324 & 842849 \\
\hline Rejeições pelo CAR & 18 & 8 \\
\hline Descartes & 10 & 4 \\
\hline Admissões & 846299 & 842834 \\
\hline Retiradas das Filas & 1550 & 534 \\
\hline Términos & 844608 & 842165 \\
\hline Throughput(Req/Seg) & 446.410147991543 & 445.118921775898 \\
\hline
\end{tabular}

Tabela 7.13: Resultados sobre Requisições para CAS em conjunto com CAR por Tamanho de Fila com Negociação de Sessão Mais Recente utilizando o método 2 de leitura do log Recente 


\subsubsection{Comparação dos resultados para os CAS com CAR Tamanho de Fila e Negociação de Sessão Mais Recente e Menor Duração}

As Tabelas 7.14 e 7.15 mostram que o CAS Baseado em Sessão Modelo, atende a um maior número de sessões quando simulado em conjunto com o CAR por TF Baseado em Sessões, cuja política de negociação para descarte de sessões utilizada foi a de menor duração. Porém, o CAS que segue a política Hard-Threshold para descarte de sessões, atende a mais requisições, visto nas Tabelas 7.16 e 7.17, mesmo para maior quantidade de sessões canceladas pelo CAR. Por isso, visto que o CAS Hard-Threshold não rejeitou sessão alguma, as sessões rejeitadas pelo CAR cumpriu seu objetivo de atendimento de sessões mais longas, já que para um menor numero de sessões atendidas foi obtido maior quantidade de requisições atendidas.

Para o CAS baseado em Sessões modelo, apesar de ter atendido maior quantidade de sessões, a baixa quantidade de requisições atendida permite concluir que as sessões rejeitadas pelo CAS foram aquelas que tinham maior número de requisições.

\begin{tabular}{|l|r|r|}
\hline Informações sobre Sessões & CAS Hard-Threshold & CAS Sessão Modelo \\
\hline \hline Chegadas ao sistema & 12053 & 12053 \\
\hline Rejeições pelo CAS & 0 & 289 \\
\hline Admissões & 12053 & 11764 \\
\hline Cancelamentos pelo CAR & 627 & 312 \\
\hline Términos & 10285 & 10311 \\
\hline Throughput(Sess/Seg) & 5.436046512 & 5.449788584 \\
\hline
\end{tabular}

Tabela 7.14: Resultados sobre Sessões para CAS em conjunto com CAR por Tamanho de Fila com Negociação de Sessão Mais Recente e de Menor Duração utilizando o método 1 de leitura do $\log$

\begin{tabular}{|l|r|r|}
\hline Informações sobre Sessões & CAS Hard-Threshold & CAS Sessão Modelo \\
\hline \hline Chegadas ao sistema & 21277 & 21277 \\
\hline Rejeições pelo CAS & 2745 & 3148 \\
\hline Admissões & 18534 & 18126 \\
\hline Cancelamentos pelo CAR & 756 & 313 \\
\hline Términos & 15737 & 15772 \\
\hline Throughput(Sess/Seg) & 8.3176532769556 & 8.33615221987315 \\
\hline
\end{tabular}

Tabela 7.15: Resultados sobre Sessões para CAS em conjunto com CAR por Tamanho de Fila com Negociação de Sessão Mais Recente e de Menor Duração utilizando o método 2 de leitura do $l o g$ 


\begin{tabular}{|l|r|r|}
\hline Informações sobre Requisições & CAS Hard-Threshold & CAS Sessão Modelo \\
\hline \hline Chegadas ao sistema & 716357 & 715221 \\
\hline Rejeições pelo CAR & 1 & 1 \\
\hline Descartes & 20 & 7 \\
\hline Admissões & 716350 & 715216 \\
\hline Retiradas das Filas & 1068 & 587 \\
\hline Términos & 715282 & 714629 \\
\hline Throughput(Req/Seg) & 377.9883721 & 377.6490486 \\
\hline
\end{tabular}

Tabela 7.16: Resultados sobre Requisições para CAS em conjunto com CAR por Tamanho de Fila com Negociação de Sessão Mais Recente e de Menor Duração utilizando o método 1 de leitura do $\log$

\begin{tabular}{|l|r|r|}
\hline Informações sobre Requisições & CAS Hard-Threshold & CAS Sessão Modelo \\
\hline \hline Chegadas ao sistema & 845729 & 843735 \\
\hline Rejeições pelo CAR & 0 & 1 \\
\hline Descartes & 19 & 5 \\
\hline Admissões & 845726 & 843730 \\
\hline Retiradas das Filas & 1371 & 573 \\
\hline Términos & 844200 & 843018 \\
\hline Throughput(Req/Seg) & 446.194503171247 & 445.56976744186 \\
\hline
\end{tabular}

Tabela 7.17: Resultados sobre Requisições para CAS em conjunto com CAR por Tamanho de Fila com Negociação de Sessão Mais Recente e de Menor Duração utilizando o método 2 de leitura do $\log$ 


\subsubsection{Comparação dos resultados para os CAS com CAR Tamanho de Fila e Negociação de Sessão Mais Recente, Maior Duração e de Classe Baixa}

Os resultados das Tabelas 7.18 e 7.19 sobre sessões e as Tabelas 7.20 e 7.21 foram obtidos de simulações onde o CAR baseado em sessões, com a política de negociação de descarte de sessões que considera o atendimento prioritário de sessões de classe 1, foi utilizado. Observa-se que o número de sessões atendidas para o CAS - Sessão Modelo, apresenta uma discreta vantagem no atendimento de sessões e requisições.

Baseado nos resultados, pode-se concluir que as sessões rejeitadas pelo CAS - Sessão Modelo não foram as que possuíam maior quantidade de requisições. Sendo um cenário diferente do apresentado anteriormente, com a prioridade de atendimento de sessões de classe 1 e não somente daquelas de menor duração. Com isso, menos sessões foram canceladas, já que provavelmente sessões mais longas não ocuparam muito tempo o buffer de sessões ativas.

\begin{tabular}{|l|r|r|}
\hline Informações sobre Sessões & CAS Hard-Threshold & CAS Sessão Modelo \\
\hline \hline Chegadas ao sistema & 12053 & 12053 \\
\hline Rejeições pelo CAS & 16 & 289 \\
\hline Admissões & 12053 & 11764 \\
\hline Cancelamentos pelo CAR & 556 & 276 \\
\hline Términos & 10340 & 10347 \\
\hline Throughput(Sess/Seg) & 5.465116279 & 5.468816068 \\
\hline
\end{tabular}

Tabela 7.18: Resultados sobre Sessões para CAS em conjunto com CAR por Tamanho de Fila com Negociação de Sessão Mais Recente e de Menor Duração e de Classe Baixa utilizando o método 1 de leitura do $\log$

\begin{tabular}{|l|r|r|}
\hline Informações sobre Sessões & CAS Hard-Threshold & CAS Sessão Modelo \\
\hline \hline Chegadas ao sistema & 21277 & 21277 \\
\hline Rejeições pelo CAS & 2828 & 3160 \\
\hline Admissões & 18447 & 18117 \\
\hline Cancelamentos pelo CAR & 607 & 2856 \\
\hline Términos & 15799 & 15791 \\
\hline Throughput(Sess/Seg) & 8.35042283298097 & 8.34619450317124 \\
\hline
\end{tabular}

Tabela 7.19: Resultados sobre Sessões para CAS em conjunto com CAR por Tamanho de Fila com Negociação de Sessão Mais Recente e de Menor Duração e de Classe Baixa utilizando o método 2 de leitura do $\log$ 


\begin{tabular}{|l|r|r|}
\hline Informações sobre Requisições & CAS Hard-Threshold & CAS Sessão Modelo \\
\hline \hline Chegadas ao sistema & 716144 & 715579 \\
\hline Rejeições pelo CAR & 0 & 0 \\
\hline Descartes & 5 & 4 \\
\hline Admissões & 716141 & 715574 \\
\hline Retiradas das Filas & 1497 & 744 \\
\hline Términos & 714644 & 714830 \\
\hline Throughput(Req/Seg) & 377.6575053 & 377.7573996 \\
\hline
\end{tabular}

Tabela 7.20: Resultados sobre Requisições para CAS em conjunto com CAR por Tamanho de Fila com Negociação de Sessão Mais Recente e de Menor Duração e de Classe Baixa utilizando o método 1 de leitura do $\log$

\begin{tabular}{|l|r|r|}
\hline Informações sobre Requisições & CAS Hard-Threshold & CAS Sessão Modelo \\
\hline \hline Chegadas ao sistema & 844464 & 843916 \\
\hline Rejeições pelo CAR & 1 & 0 \\
\hline Descartes & 6 & 2 \\
\hline Admissões & 844460 & 843913 \\
\hline Retiradas das Filas & 1751 & 741 \\
\hline Términos & 842568 & 843035 \\
\hline Throughput(Req/Seg) & 445.331923890063 & 445.578752642706 \\
\hline
\end{tabular}

Tabela 7.21: Resultados sobre Requisições para CAS em conjunto com CAR por Tamanho de Fila com Negociação de Sessão Mais Recente e de Menor Duração e de Classe Baixa utilizando o método 2 de leitura do $\log$ 


\subsubsection{Comparação dos resultados para os CAS com CAR Tamanho de Fila e Negociação de Sessão Mais Recente e de Menor Tamanho}

Os resultados das Tabelas 7.22 e 7.23 sobre sessões e das Tabelas 7.24 e 7.25 mostra que mais uma vez o CAS baseado em sessão modelo atende um maior número de sessões, sendo que para isso, menos requisições tiveram que ser retiradas das filas. Com isso, o algoritmo de negociação melhor se adequou ao CAS baseado em sessões, para o qual cancelou menos requisições e conseqüentemente, menos sessões.

\begin{tabular}{|l|r|r|}
\hline Informações sobre Sessões & CAS Hard-Threshold & CAS Sessão Modelo \\
\hline \hline Chegadas ao sistema & 12053 & 12053 \\
\hline Rejeições pelo CAS & 0 & 289 \\
\hline Admissões & 12053 & 11764 \\
\hline Cancelamentos pelo CAR & 606 & 280 \\
\hline Términos & 10306 & 10343 \\
\hline Throughput(Sess/Seg) & 5.447145877 & 5.466701903 \\
\hline
\end{tabular}

Tabela 7.22: Resultados sobre Sessões para CAS em conjunto com CAR por Tamanho de Fila com Negociação de Sessão Mais Recente e de Menor Tamanho utilizando o método 1 de leitura do $\log$

\begin{tabular}{|l|r|r|}
\hline Informações sobre Sessões & CAS Hard-Threshold & CAS Sessão Modelo \\
\hline \hline Chegadas ao sistema & 21277 & 21277 \\
\hline Rejeições pelo CAS & 2719 & 3163 \\
\hline Admissões & 18556 & 18113 \\
\hline Cancelamentos pelo CAR & 811 & 287 \\
\hline Términos & 15704 & 15785 \\
\hline Throughput(Sess/Seg) & 8.30021141649048 & 8.34302325581395 \\
\hline
\end{tabular}

Tabela 7.23: Resultados sobre Sessões para CAS em conjunto com CAR por Tamanho de Fila com Negociação de Sessão Mais Recente e de Menor Tamanho utilizando o método 2 de leitura do $\log$ 


\begin{tabular}{|l|r|r|}
\hline Informações sobre Requisições & CAS Hard-Threshold & CAS Sessão Modelo \\
\hline \hline Chegadas ao sistema & 716695 & 715979 \\
\hline Rejeições pelo CAR & 2 & 0 \\
\hline Descartes & 16 & 9 \\
\hline Admissões & 716676 & 715968 \\
\hline Retiradas das Filas & 1170 & 467 \\
\hline Términos & 715393 & 715389 \\
\hline Throughput(Req/Seg) & 378.1146934 & 378.1125793 \\
\hline
\end{tabular}

Tabela 7.24: Resultados sobre Requisições para CAS em conjunto com CAR por Tamanho de Fila com Negociação de Sessão Mais Recente e de Menor Tamanho utilizando o método 1 de leitura do $\log$

\begin{tabular}{|l|r|r|}
\hline Informações sobre Requisições & CAS Hard-Threshold & CAS Sessão Modelo \\
\hline \hline Chegadas ao sistema & 845952 & 842956 \\
\hline Rejeições pelo CAR & 1 & 1 \\
\hline Descartes & 15 & 6 \\
\hline Admissões & 845933 & 842947 \\
\hline Retiradas das Filas & 1524 & 492 \\
\hline Términos & 844274 & 842319 \\
\hline Throughput(Req/Seg) & 446.233615221987 & 445.200317124735 \\
\hline
\end{tabular}

Tabela 7.25: Resultados sobre Requisições para CAS em conjunto com CAR por Tamanho de Fila com Negociação de Sessão Mais Recente e de Menor Tamanho utilizando o método 2 de leitura do $\log$ 


\subsubsection{Comparação Final}

O Gráficos 7.1 e 7.2 exibem resutados sobre as quantidades de sessões atendidas por segundo (Throughput) com os métodos 1 e 2 de leitura do log empregados, respectivamente, obtidos de experimentos onde cada controle de admissão de sessão foi utilizado em conjunto com um controle de admissão de requisições. Somente para o primeiro resultado as políticas Hard-Threshold e Sessão Modelo foram utilizadas sem controles de requisições.

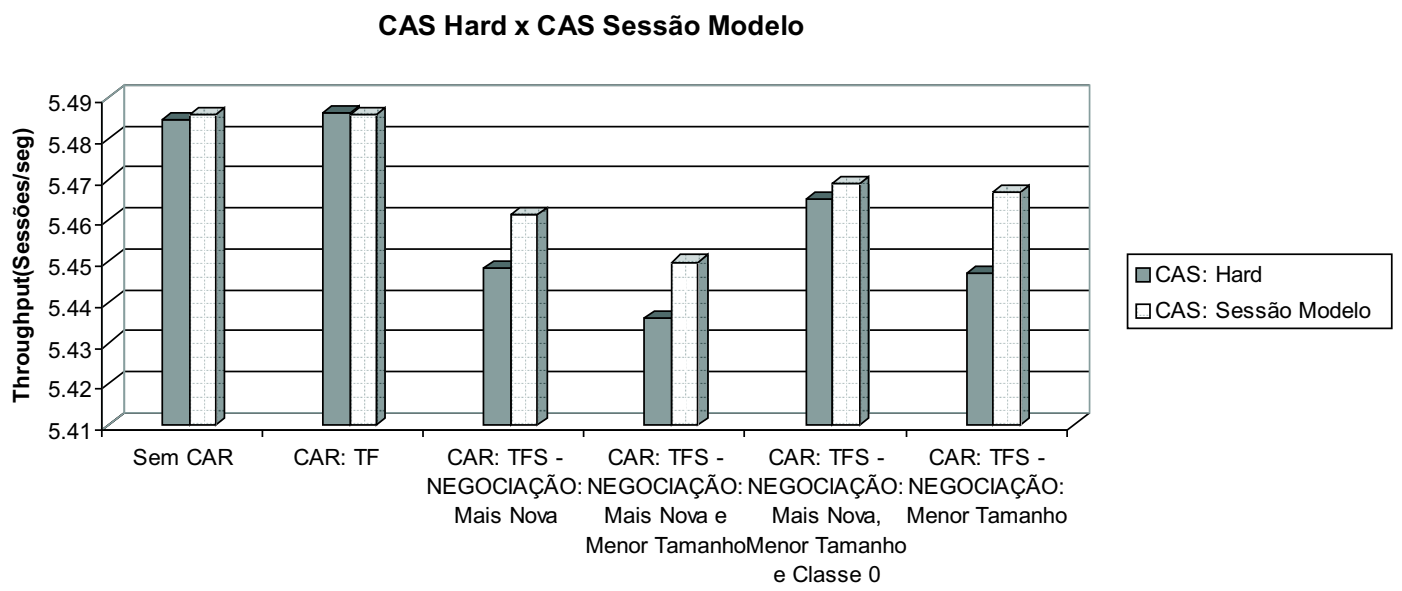

Figura 7.1: Throughput (Sessões/seg) para os CAS em conjunto com CAR utilizando o método 1 de leitura do $\log$

Hard-Threshold x Sessão Modelo

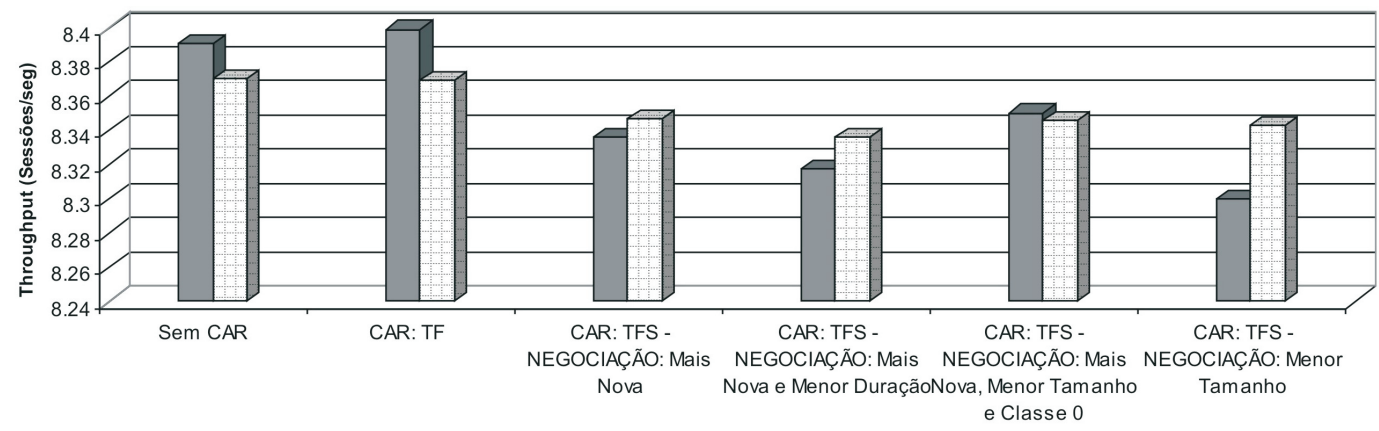

Figura 7.2: Throughput (Sessões/seg) para os CAS em conjunto com CAR utilizando o método 2 de leitura do $\log$ 


\subsection{Considerações Finais}

Neste capítulo foram descritos os mecanismos de controle de admissão de requisições, criados para o atendimento de requisições, mas também com a visão de atendimento às sessões, já que a rejeição de uma requisição implica no cancelamento da sessão correspondente.

Foram também explicadas as políticas de negociação empregadas no mecanismo de controle para a escolha de requisições a serem rejeitadas, buscando melhores maneiras para evitar que serviços dos recursos do sistema sejam desperdiçados, além de prezar por garantias de atendimento às sessões.

Foram exibidos os resultados obtidos de experimentos onde os controles de admissão de requisições foram utilizados solitariamente e em conjunto com os controle de admissão de sessões, bem como, comparações do resultados foi realizada de modo a avaliar o desempenho dos controles desenvolvidos.

No próximo capítulo serão apresentadas as conclusões e as principais contribuições desta tese. 



\section{Conclusão}

\subsection{Visão Geral}

A finalidade deste trabalho foi adaptar o modelo de Servidor Web com Diferenciação de Serviços (SWDS) à característica de reconhecimento de sessões. A idéia para o tema surgiu como um trabalho futuro proposto por Teixeira (2004), integrante do grupo LaSDPC, em sua tese de doutorado, onde desenvolveu o modelo SWDS.

A principal motivação para incorporar esta característica ao modelo SWDS é a crescente demanda de serviços na Web, como comércio eletrônico, transações bancárias entre outros, onde faz-se necessária a utilização de sessões HTTP para a realização de suas tarefas. Com o crescimento do número de seus adeptos, a Web tem se tornado um potencial gerador de sobrecargas aos servidores.

Neste cenário, garantias de atendimento aos clientes devem ser fornecidos, além de que os servidores de sites atuais, devem se tornar preparados, caso ocorram sobrecargas no sistema. Além disso, torna-se de grande importância haver diferenciação no atendimento das sessões, já que os mais diversos serviços podem ser encontrados atualmente na Web e nem todos possuem a mesma prioridade de atendimento. Motivado pelo cenário atual da Web, este trabalho propôs políticas para controlar o atendimento de sessões, e o atendimento de requisições com atenção voltada às sessões.

Para o domínio do assunto estudado neste trabalho, foram revisados diversos tópicos pertinentes à área. A infra-estrutura da Web foi discutida no Capítulo 2, juntamente com os aspectos que lhe dão suporte, o protocolo HTTP e as sessões HTTP, cujo conceito é 
de especial importância para este trabalho. No Capítulo 3 foram discutidas as limitações do modelo de serviços da Internet atual, o qual motivou o tema desta dissetação. Foram descritos os conceitos de qualidade de serviço, com destaque para as arquiteturas de serviços integrados e diferenciados. Discutiu-se ainda, a necessidade de se oferecer qualidade de serviço em nível de aplicação na Internet, em particular, nos servidores web.

O Capítulo 4 apresentou o modelo SWDS, Servidor Web com Diferenciação de Serviços, o qual consiste em uma arquitetura para o fornecimento de serviços diferenciados em servidores web. Seus principais componentes foram descritos, com especial atenção para o módulo de Controle de Admissão, no qual novas políticas de admissão de requisições, baseadas em sessões, foram empregadas por este trabalho. Foi ainda descrita de forma geral, os algoritmos de diferenciação de serviços e de controle de admissão implementados no modelo. Finalmente, foram apontados alguns cenários de utilização de serviços diferenciados na Web.

No Capítulo 5 foi apresentada a proposta de incorporação do módulo de reconhecimento de sessões ao modelo SWDS e explicou-se o método utilizado para o reconhecimento das sessões. Apresentou-se de modo geral o estudo de Arlitt (Arlitt, 2000) sobre a caracterização de sessões no $\log$ da Copa do Mundo de 1998, na França, o qual serviu de base para a construção da carga de trabalho utilizada para os experimentos realizados. Comentou-se ainda sobre a abordagem utilizada para a validação do modelo, a simulação. O processo de classificação das requisições foi também monstrado, pelo qual será feita a diferenciação no atendimento de sessões.

A principal contribuição deste trabalho foi descrita no Capítulo 6. O módulo de Controle de Admissão de Sessões foi desenvolvido e incorporado ao modelo SWDS para proporcionar atendimento mais adequado à sessões HTTP. Foram desenvolvidas duas políticas de controle de admissão de sessões, cujo principal objetivo é atender completamente todas sessões ativas no sistema, que para isso, rejeita novas sessões quando o sistema se apresenta sobrecarregado. Adicionalmente, esse controle ainda contribui para evitar sobrecargas no sistema. Uma política se baseia estritamente no número de sessões ativas no sistema, onde um limiar é utilizado como parâmetro para a aceitação ou rejeição de uma sessão, esta política é denominada como Hard-Threshold. A política de admissão de sessões Baseada em Sessão Modelo foi construída com um controle mais elaborado para admitir uma sessão no sistema. Utilizando-se de um modelo de sessão, construído por informações de um histórico de sessões, o controle admite ou rejeita novas sessões chegadas no sistema.

O Capítulo 7 descreve a necessidade de se ter um controle sobre a carga de trabalho a 
qual o servidor está exposto. O módulo de Controle de Admissão de Requisições é responsável por coletar informações sobre a carga de trabalho presente ao sistema e gerenciar a aceitação de novas requisições pelo servidor. Neste capítulo mostrou-se a necessidade de implementação de novas políticas que se adaptassem ao atendimento de sessões. Para tanto, foram criadas duas políticas de admissão de requisições, ambas baseadas em informações sobre o tamanho das filas do cluster, e baseadas em sessões. A diferença entre elas está no modo de rejeição de uma requisição, onde uma das políticas possui a característica de negociação, pela qual, busca uma requisição mais adequada para ser retirada do sistema, baseando-se nas sessões ativas. Com isso, a diferenciação de atendimento de sessões é realizada.

\subsection{Principais Resultados e Contribuições}

Os principais resultados deste trabalho são relacionados a seguir, destacando-se as contribuições feitas ao modelo de Servidor Web com diferencição de Serviços e, conseqüentemente, relevantes para a área.

1. Revisão Bibliográfica - Foi feita uma revisão crítica da bibliografia existente, a fim de contextualizar o presente trabalho. A revisão foi feita em torno de informações sobre o fornecimento de serviços diferenciados, em nível de rede e nos servidores web. Revisou-se também o modelo de Servidor Web com Diferenciação de Serviços, do qual o presente trabalho teve sua origem e a caracterização de sessões, a qual foi de grande utilidade para o processo de reconhecimento de sessões e da geração da carga utilizada para este trabalho.

2. Geração da Carga de Trabalho - Foram estudadas diferentes abordagens para a geração da carga de trabalho para as simulações, tanto de forma sintética quanto usando traces de acesso a servidores web reais. Para este trabalho, utilizou-se o $\log$ da Copa do Mundo de 98, onde o estudo das características de sessões contribuiu para a geração da carga.

3. Reconhecimento de Sessões - Foi criado um módulo de reconhecimento de sessões no modelo SWDS, que em sua constituição original era capaz de atender somente requisições de modo isolado, sem o conhecimento de qual sessão elas pertenciam.

4. Controle de Admissão de Sessões - Foi desenvolvido um controle de admissão de sessões para o modelo SWDS, com o qual, o modelo de servidor pôde fornecer aos cliente 
uma maior qualidade de atendimento, que passou não somente a ter a preocupação em nível de requisições, mas em nível de sessões.

5. Mecanismos de Controle de Admissão de Sessões: Foram implementados dois mecanismos para controlar a admissão de sessões, os quais possuem a grande preocupação de que as sessões ativas no sistema sejam finalizadas, onde todas suas requisições devem ser atendidas pelo servidor.

Admissão de sessões Hard-Threshold: por meio de informações de um buffer de sessões ativas no sistema, esta política toma decisões para aceitar uma nova sessão. A este buffer é atribuído uma capacidade máxima e caso este limiar Threshold seja atingido, o controle rejeita qualquer nova sessão chegada ao sistema. Esta política não realiza qualquer tipo de previsão para saber se o sistema será capaz de atender a uma sessão completamente, ou seja, atender todas suas requisições. No entanto, mesmo com este controle o sistema se apresenta suscetível a sobrecargas.

Admissão de sessões Baseada em Sessão Modelo: utilíza-se de um modelo de sessão, gerado apartir de informações de um histórico de sessões, para prever se o sistema comportará o atendimento de todas as requisições futuras da nova sessão chegada ao sistema. Se a previsão assegurar que o sistema se apresenta capaz de atender completamente a nova sessão, ela será aceita pelo controle, caso contrário a sessão será rejeitada, evitando seu possível cancelamento.

6. Mecanismos de Controle de Admissão de Requisições - Foram implementados dois mecanismos para controlar a aceitação de requisições, baseando-se em informações de sessões ativas no sistema.

Admissão segundo o Tamanho das Filas sem Negociação: este mecanismo estabelece um limite superior para o tamanho das filas dos nós do cluster. Caso este limite seja atingido, quaisquer novas requisições serão recusadas e suas respectivas sessões serão canceladas. Embora consiga diminuir a sobrecarga ao servidor, garantias de QoS não são fornecidas, uma vez que qualquer requisição ou sessão será descartada.

Admissão segundo o Tamanho das Filas com Negociação: este mecanismo emprega o mesmo método do citado anteriormente, ou seja, baseia-se no tamanho das filas, no entanto, ele se utiliza de políticas de admissão de requisições baseadas em sessões. 
7. Políticas de Negociação para Descarte de Sessões - Foram implementadas três políticas para a escolha de qual sessão uma requisição deverá ser descartada e, conseqüentemente, a sua sessão cancelada.

Negociação por sessão mais recente: esta política procura descartar sessões que se apresentam há menos tempo no sistema, com o objetivo de priorizar o atendimento de sessões mais antigas, que por sua vez possuem maior probabilidade de finalização.

Negociação por sessão mais recente e por menor duração: nesta política a sessão escolhida para ser descartada é aquela que além de estar ativa a menos tempo no sistema, o tempo entre sua primeira e última requisição é o menor entre os tempos das sessões ativas. Com isso, o atendimente à sessões mais longas é priorizado.

Negociação por sessão mais recente, e menor tempo de duração e de classe baixa: Com esta política, o sistema prioriza o atendimento de sessões de maior prioridade, ou seja, sessões classificadas como de classe 1. O princípio desta política é garantir o atendimento de sessões conforme o acordo de serviço (SLA) pré-estabelecido.

Negociação por sessão mais recente e de menor tamanho: nesta política a sessão escolhida para ser descartada é aquela que além de estar ativa a menos tempo no sistema, enviou menor quantidade de requisições ao servidor, procurando não desperdiçar processamento já realizado para a sessão cancelada, além de priorizar o atendimento à sessões que possuem maior atividade.

\subsection{Trabalhos Futuros}

A proposta de incorporação da característica de reconhecimento de sessões ao modelo SWDS, traz consigo várias sugestões para trabalhos futuros relacionados ao oferecimento de serviços diferenciados à sessões.

Este trabalho contribuiu com a incorporação da característica de reconhecimento de sessão ao SWDS e para a adaptação do controle de admissão de requisições a esta nova característica com o desenvolvimento de políticas de admissão de requisições baseadas em sessões. No entanto, novos algoritmos poderão ser desenvolvidos para esse controle, como também, novos mecanismos de diferenciação de serviços baseados em sessões poderão ser criados. A seguir serão comentadas algumas sugestões para trabalhos futuros. 
- Carga de Trabalho: Estudar a fundo o perfil de carga de trabalho que contenha características de sessões e construir um gerador da carga de trabalho de forma sintética que possua características de sessões HTTP, para melhor validar o modelo SWDS com a característica de reconhecimento de sessões incorporada;

- Classificação de Sessões: Experimentar novas abordagens para a categorização de sessões no módulo Classificador, tomando como parâmetros, a urgência de atendimento, tipo de Sessões HTTP, dentre outros;

- Mecanismos de Diferenciação de Serviços: Novos mecanismos de diferenciação de serviços deverão ser criados tomando como base o atendimento de sessões. A importância na qualidade de serviços oferecidos passa a ser não somente relativos ao atendimento de classes de requisições, mas também de classes de sessões;

- Controle de Admissão de Requisições: Desenvolver novos mecanismos de controle de admissão de requisições para um melhor atendimento de sessões;

- Controle de Admissão de Sessões: Desenvolver novos mecanismos de admissão de sessões, em especial, políticas que façam diferenças entre as classes de sessões.

- Interface do SWDS com Reconhecimento de Sessões: Projeto e implementação de uma interface para o SWDS com o reconhecimento de sessões, através da qual se poderá especificar a parametrização do modelo, incluindo os parâmetros relacionados ao tratamento de sessões.

- Protótipo do SWDS com Reconhecimento de Sessões: Implementação de um protótipo do servidor SWDS, com a capacidade de reconhecer sessões, em um sistema distribuído. 


\section{Referências Bibliográficas}

Almeida, V.; Bestavros, A.; Crovella, M.; de Oliveira, A. (1996). Characterizing reference locality in the www. DIS '96: Proceedings of the fourth international conference on on Parallel and distributed information systems, p. 92-107. IEEE Computer Society.

Andreolini, M.; Casalicchio, E.; Colajanni, M.; Mambelli, M. (2004). A cluster-based web system providing differentiated and guaranteed services. Cluster Computing, v.7, n.1, p.7-19.

Ardaiz, O.; Freitag, F.; Navarro, L. (2001). Estimating the service time of web clients using server logs. SIGCOMM Comput. Commun. Rev., v.31, n.2 supplement, p.108-123.

Arlitt, M. (2000). Characterizing web user sessions. SIGMETRICS Perform. Eval. Rev., v.28, n.2, p.50-63.

Arlitt, M. F.; Jin, T. (1999). Workload characterization of the 1998 World Cup web site. Relatório Técnico HPL-1999, HP Laboratories.

Arlitt, M. F.; Williamson, C. L. (1996). Web server workload characterization: the search for invariants. Proceedings of ACM SIGMETRICS ' 96.

Barford, P.; Bestavros, A.; Bradley, A.; Crovella, M. (1998). Changes in web client access patterns: Characteristics and caching implications. Relatório Técnico 1998-023, Boston University.

Barford, P.; Crovella, M. (1999). A performance evaluation of hyper text transfer protocols. p. $188-197$.

Berger, L., editor (2003). Generalized Multi-Protocol Label Switching (GMPLS) Signaling Resource ReserVation Protocol-Traffic Engineering (RSVP-TE) Extensions. RFC 3473, IETF. 
Berners-Lee, T.; Fielding, R.; Frystyk, H. (1996). Hypertext Transfer Protocol - HTTP/1.0. RFC 1945, IETF.

Blake, S.; Black, D.; Carlson, M.; Davies, E.; Wang, Z.; Weiss, W. (1998). An Architecture for Differentiated Services. RFC 2475, IETF.

Borenstein, N. (1993). MIME (Multipurpose Internet Mail Extensions) Part One: Mechanisms for Specifying and Describing the Format of Internet Message Bodies. RFC 1521, IETF.

Bouch, A.; Kuchinsky, A.; Bhatti, N. (2000). Quality is in the eye of the beholder: meeting users' requirements for internet quality of service. CHI '00: Proceedings of the SIGCHI conference on Human factors in computing systems, p. 297-304. ACM Press.

Braden, R.; Clark, D.; Shenker, S. (1994). Integrated Services in the Internet Architecture. RFC 1633, IETF.

Braden, R.; Zhang, L.; Berson, S.; Herzog, S.; Jamin, S. (1997). Resource ReSerVation Protocol (RSVP) - Version 1 Functional Specification. RFC 2205, IETF.

Calzarossa, M.; Massari, L.; Tessera, D. (2000). Workload characterization issues and methodologies. Performance Evaluation: Origins and Directions, p. 459-481. SpringerVerlag.

Cathy, H. Xia and Zhen Liu and Mark S. Squillante and Li Zhang and Naceur Malouch (2005). Web traffic modeling at finer time scales and performance implications. Perform. Eval., v.61, n.2-3, p.181-201.

Cherkasova, L.; Gupta, M. (2002). Characterizing locality, evolution, and life span of accesses in enterprise media server workloads. NOSSDAV '02: Proceedings of the 12th international workshop on Network and operating systems support for digital audio and video, p. 33-42.

Cherkasova, L.; Phaal, P. (2002). Session-based admission control: A mechanism for peak load management of commercial web sites. IEEE Trans. Comput., v.51, n.6, p.669-685.

Cisco (2005). Internetworking technology handbook. Disponível em: http://www.cisco.com/univercd/cc/td/doc/cisintwk/ito_doc/.

Comer, D. E. (2006). Internetworking with TCP/IP: Principles, Protocols and Architecture. Prentice Hall, 5. edição. 
Coulouris, G.; Dollimore, J.; Kindberg, T. (2000). Distributed Systems: Concepts and Design. Addison-Wesley, 3. edição.

Cubert, R. M.; Fishwick, P. (1995). Sim++: Version 1.0. university of florida. Disponível

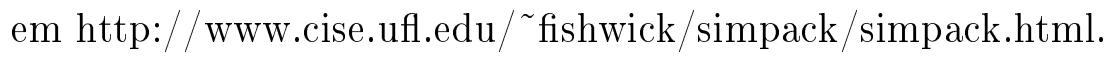

Dovrolis, C.; Ramanathan, P. (1999). A case for relative differentiated services and the proportional differentiation model. IEEE Network.

Elbaum, S.; Karre, S.; Rothermel, G. (2003). Improving web application testing with user session data. ICSE '03: Proceedings of the 25th International Conference on Software Engineering, p. 49-59. IEEE Computer Society.

Elnikety, S.; Nahum, E.; Tracey, J.; Zwaenepoel, W. (2004). A method for transparent admission control and request scheduling in e-commerce web sites. $W W W$ '04: Proceedings of the 13th international conference on World Wide Web, p. 276-286. ACM Press.

Fielding, R.; Gettys, J.; Mogul, J.; Frystyk, H.; Masinter, L.; Leach, P.; Berners-Lee, T. (1999). Hypertext Transfer Protocol - HTTP/1.1. RFC 2616, IETF.

Fishwick, P. A. (1992). Simpack: Getting started with simulation programming in c and c++. Winter Simulation Conference, p. 154-162.

Fishwick, P. A. (2006a). Java version of simpack (SimPackJ). Disponível em: http://www.cise.ufl.edu/ fishwick/simpackj/doc/index.html.

Fishwick, P. A. (2006b). SimPack: Simulation Programming. Disponível em: http://www.cise.ufl.edu/ fishwick/simpackj/.

Galbraith, R.; Turnbull, J.; Dearnaley, R.; Hart, J.; Nolde, K. (2005). Do we need quality of service in the customer environment? BT Technology Journal, v.23, n.2, p.146-159.

Ghinea, G.; Angelides, M. C. (2004). A user perspective of quality of service in m-commerce. Multimedia Tools Appl., v.22, n.2, p.187-206.

Giordano, S. and Listanti, M. and Mustacchio, F. and Niccolini, S. and Salsano, S. and Veltri, L. (2004). Dynamic resource configuration in diffserv networks: control plane mechanisms and performance evaluation of a traffic control api. Comput. Networks, v.44, n.4, p.513-527.

Heinanen, J.; Baker, F.; Weiss, W.; Wroclawski, J. (1999). Assured Forwarding PHB Group. RFC 2597, IETF. 
Hong, Y. S.; No, J. H.; Kim, S. Y. (2006). DNS-Based Load Balancing in Distributed Web-server Systems. SEUS-WCCIA '06: Proceedings of the The Fourth IEEE Workshop on Software Technologies for Future Embedded and Ubiquitous Systems, and the Second International Workshop on Collaborative Computing, Integration, and Assurance (SEUSWCCIA'06), p. 251-254. IEEE Computer Society.

Hunt, C. (2002). TCP/IP Network Administration. O’Reilly, 3. edição.

Hunt, G.; Arden, P. (2005). Qos requirements for a voice-over-ip pstn. BT Technology Journal, v.23, n.2, p.37-47.

Internet Traffic Archive (1998). World Cup Web site access logs. Disponível em http://ita.ee.lbl.gov/html/contrib/WorldCup.html.

Iyer, R. (2004). Characterization and evaluation of cache hierarchies for web servers. World Wide Web, v.7, n.3, p.259-280.

Jacobson, V.; Nichols, K.; Poduri, K. (1998). An Expedited Forwarding PHB. RFC 2598, IETF.

Kilkki, K. (1999). Differentiated Services for the Internet. Macmillan Publishing.

Krishnamurthy, B.; Zhang, Y.; Wills, C. E.; Vishwanath, K. (2003). Design, implementation, and evaluation of a client characterization driven web server. $W W W$ '03: Proceedings of the twelfth international conference on World Wide Web, p. 138-147. ACM Press.

Lee, S. C. M.; Lui, J. C. S.; Yau, D. K. Y. (2004). A proportional-delay diffserv-enabled web server: Admission control and dynamic adaptation. IEEE Trans. Parallel Distrib. Syst., v.15, n.5, p.385-400.

Li, Y.; Zhu, Q.; Cao, Y. (2005). A Request Dispatching Policy for Web Server Cluster. EEE '05: Proceedings of the 2005 IEEE International Conference on e-Technology, e-Commerce and e-Service (EEE'05) on e-Technology, e-Commerce and e-Service, p. 391-394. IEEE Computer Society.

Li, Z.; Mohapatra, P. (2004). Qos-aware multicasting in diffserv domains. SIGCOMM Comput. Commun. Rev., v.34, n.5, p.47-57.

Li, C. and Peng, G. and Gopalan, K. and Chiueh, T. (2003). Performance Guarantees for Cluster-Based Internet Services. CCGRID '03: Proceedings of the 3st International Symposium on Cluster Computing and the Grid, p. 276. IEEE Computer Society. 
Liu, F.; Zhao, Y.; Wang, W.; Makaroff, D. (2004). Database server workload characterization in an e-commerce environment. MASCOTS '04: Proceedings of the The IEEE Computer Societyýs 12th Annual International Symposium on Modeling, Analysis, and Simulation of Computer and Telecommunications Systems (MASCOTS'04), p. 475-483. IEEE Computer Society.

Magalhães, M. F.; Cardozo, E. (1999). Qualidade de serviço na Internet. Relatório técnico, UNICAMP/FEEC/DCA, Campinas, SP.

Menascé, D. A. (2002). Qos issues in web services. IEEE Internet Computing, v.6, n.6, p.72-75.

Menascé, D. A. (2003). Workload characterization. IEEE Internet Computing, v.7, n.5, p.89-92.

Menascé, D. A.; Almeida, V. A. F. (2001). Capacity Planning for Web Performance: Metrics, Modes and Methods. Prentice Hall, 2. edição.

Menascé, D. A.; Almeida, V. A. F. (2003). Planejamento de Capacidade para Serviços na Web: Métricas, modelos e métodos. Campus, 1. edição.

Menasce, D. A. (2004). Composing web services: A qos view. IEEE Internet Computing, v.8, n.6, p.88-90.

Morrison, G. (2005). Qos for applications. BT Technology Journal, v.23, n.2, p.28-36.

Nichols, K.; Blake, S.; Baker, F.; Black, D. (1998). Definition of the Differentiated Services Field (DS Field) in the IPv4 and IPv6 Headers. RFC 2474, IETF.

Olshefski, D.; Nieh, J. (2006). Understanding the management of client perceived response time. SIGMETRICS '06/Performance '06: Proceedings of the joint international conference on Measurement and modeling of computer systems, p. 240-251. ACM Press.

Orfali, R.; Harkey, D.; Edwards, J. (1999). Client/Server Survival Guide. John Wiley, 3. edição.

Postel, J. (1980). User Datagram Protocol. RFC 768, IETF.

Postel, J. (1981a). Internet Control Message Protocol. RFC 792, IETF.

Postel, J. (1981b). Internet Protocol. RFC 791, IETF. 
Postel, J. (1981c). Transmission Control Protocol. RFC 793, IETF.

Rajagopalan, B. (2003). Documentation of iana assignments for label distribution protocol (ldp), resource reservation protocol ( $\operatorname{ssvp}$ ), and resource reservation protocol-traffic engineering (rsvp-te) extensions for optical uni signaling.

Robertsson, A.; Wittenmark, B.; Kihl, M. (2003). Analysis and design of admission control in web-server systems. Disponível em: http://citeseer.csail.mit.edu/670487.html.

Rosen, E.; Viswanathan, A.; Callon, R. (2001). Multiprotocol Label Switching Architecture. RFC 3031, IETF.

Shenker, S.; Partridge, C.; Guerin, R. (1997). Specification of Guaranteed Quality of Service. RFC 2212, IETF.

Shukla, A.; Li, L.; Subramanian, A.; Ward, P. A. S.; Brecht, T. (2004). Evaluating the performance of user-space and kernel-space web servers. CASCON '04: Proceedings of the 2004 conference of the Centre for Advanced Studies on Collaborative research, p. 189-201. IBM Press.

Sopitkamol, M (2004). Ranking configuration parameters in multi-tiered e-commerce sites. SIGMETRICS Perform. Eval. Rev., v.32, n.3, p.24-33.

Stallings, W. (2002). High-Speed Networks and Internets: Performance and Quality of Service. Prentice Hall, 2. edição.

Stardust (1999a). White paper - qos protocols \& architectures. Disponível em http://www.qosforum.com.

Stardust (1999b). White Paper - The need for QoS. Disponível em http://www.qosforum.com.

Stoika, I.; Zhang, H. (1998). LIRA: An approach for service differentiation in the Internet. Proceedings of NOSSDAV.

Tanenbaum, A. S. (2002). Computer Networks. Prentice Hall, 4. edição.

Teixeira, M. M. (2004). Suporte a serviços diferenciados em servidores web: modelos e algoritmos. Teste (Doutorado), USP/ICMC, São Carlos, SP. 
Teixeira, M. M.; Santana, M. J.; Santana, R. H. C. (2004). Using adaptive priority scheduling for service differentiation in QoS-aware web servers. Proceedings of the IEEE International Performance, Computing and Communications Conference. Workshop on End-to-End Service Differentiation (IEEE IPCCC 2004).

Vallamsetty, U.; Kant, K.; Mohapatra, P. (2003). Characterization of e-commerce traffic. Electronic Commerce Research, v.3, n.1-2, p.167-192.

Vasiliou, N. (2000). Overview of Internet QoS and web server QoS. Relatório técnico, Univ. of Western Ontario, Canadá.

Vasiliou, N.; Lutfiyya, H. (2000). Providing a differentiated quality of service in a world wide web server. SIGMETRICS Perform. Eval. Rev., v.28, n.2, p.22-28.

Verma, A.; Ghosal, S. (2003). On admission control for profit maximization of networked service providers. WWW'03: Proceedings of the twelfth international conference on World Wide Web, p. 128-137. ACM Press.

W3C (1999). HTML 4.01 specification. Disponível em http://www.w3c.org/TR/html4.

W3C (2000). XHTML 1.0 The Extensible HyperText Markup Language. Disponível em http://www.w3c.org/TR/html.

W3C (2003). Extensible markup language (XML). Disponível em http://www.w3c.org/XML.

Wang, Q.; Makaroff, D. J.; Edwards, H. K. (2004). Characterizing customer groups for an e-commerce website. EC '04: Proceedings of the 5th ACM conference on Electronic commerce, p. 218-227. ACM Press.

Wei, Y.; Lin, C.; Ren, F.; Dutkiewicz, E.; Raad, R. (2003). Session based differentiated quality of service admission control for web servers. ICCNMC '03: Proceedings of the 2003 International Conference on Computer Networks and Mobile Computing, p. 112. IEEE Computer Society.

Wen, J.; Lu, X. (2002). The design of QoS guarantee network subsystem. ACM SIGOPS Operating Systems Review.

Wroclawski, J. (1997). Specification of the Controlled-Load Network Element Service. RFC 2211, IETF.

Xiao, X.; Ni, L. M. (1999). Internet QoS: a big picture. IEEE Network. 
Yeager, N. J.; McGrath, R. E. (1996). Web Server Technology: the Advanced Guide for World Wide Web Information Providers. Morgan Kaufmann.

Zhang, L.; Ardagna, D. (2004). Sla based profit optimization in autonomic computing systems. ICSOC '04: Proceedings of the 2nd international conference on Service oriented computing, p. 173-182. ACM Press.

Zhao, W.; Olshefski, D.; Schulzrinne, H. (1999). Internet quality of service: an overview. IEEE Network. 